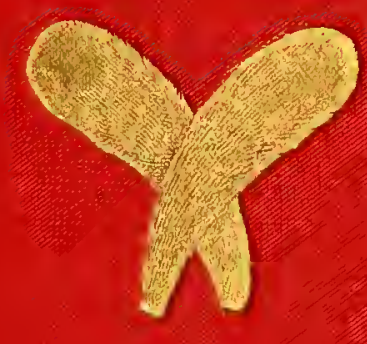




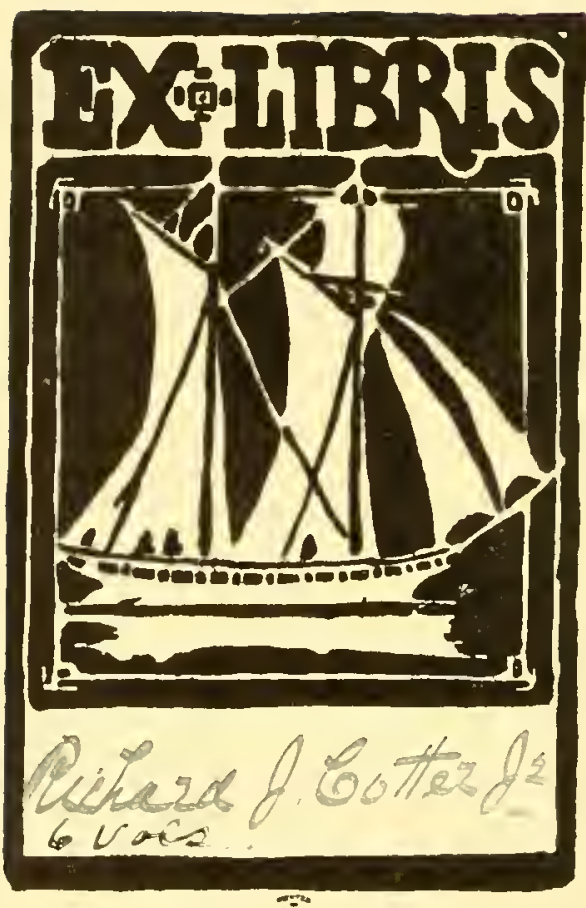

$=$ 


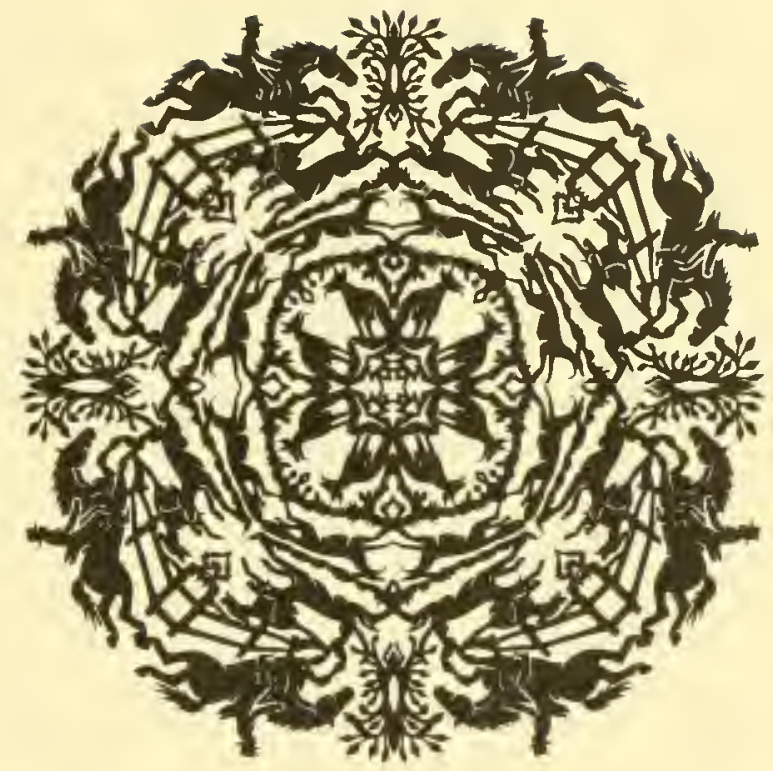

JOHN A.SEAVERNS 





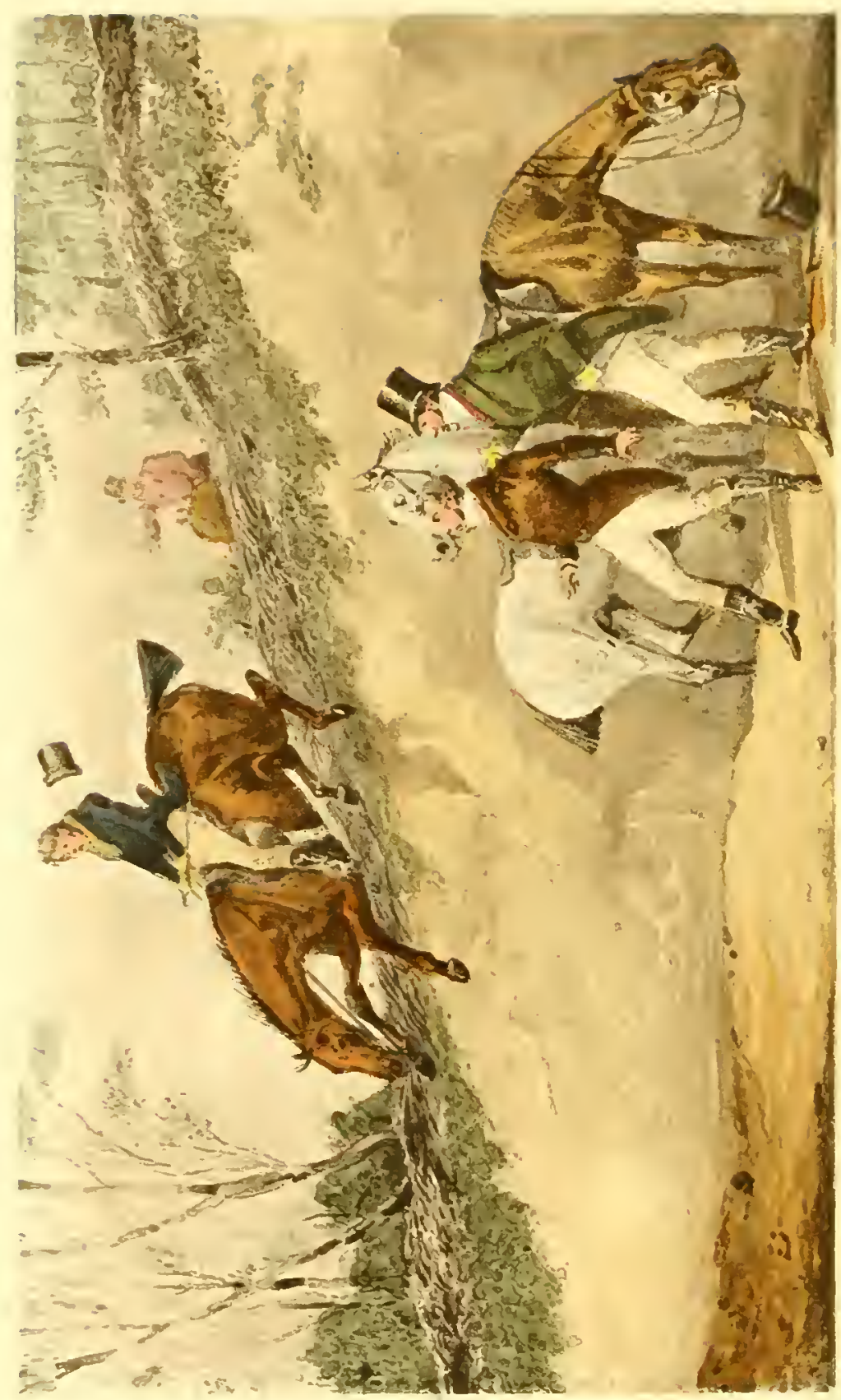




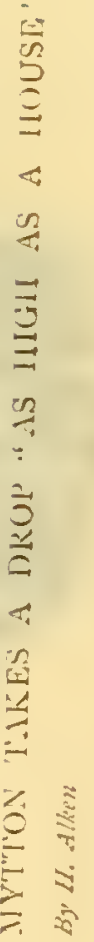




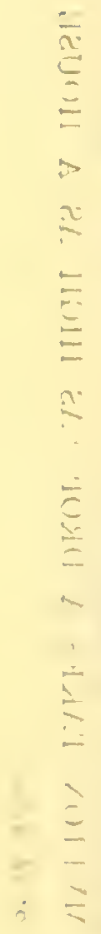




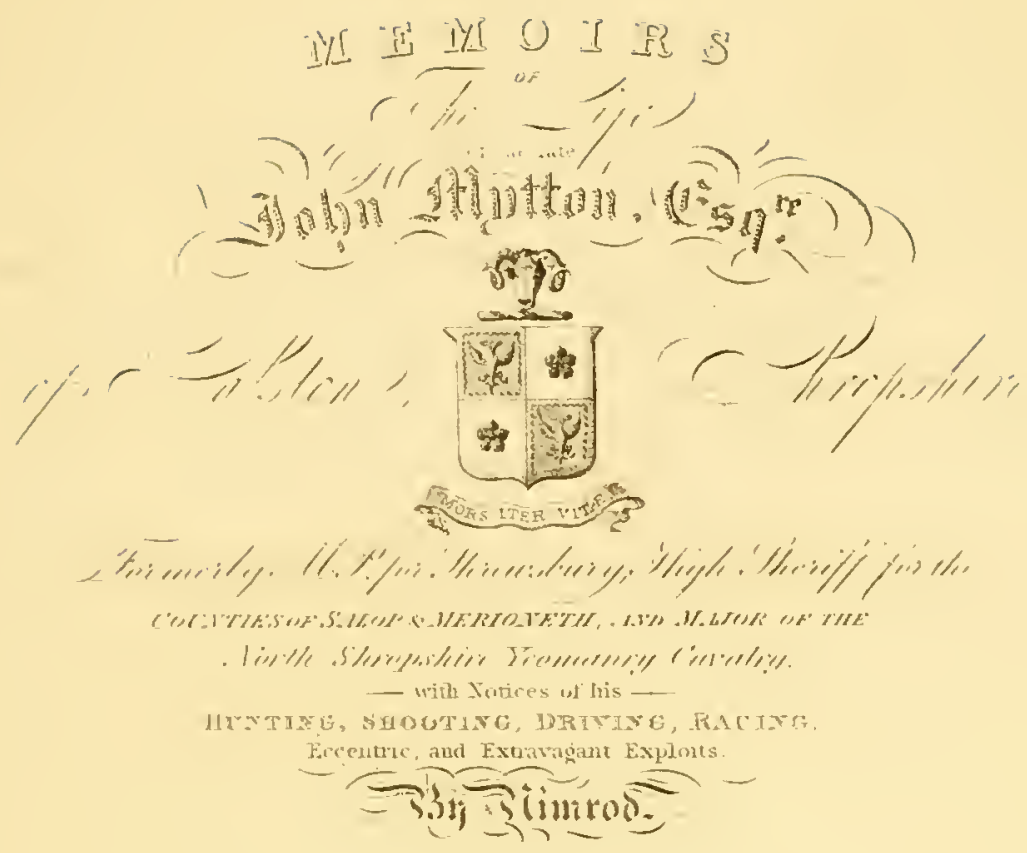

With Tumouns Illustrations, by H.ALKEN atd T.J.RAWLINS.

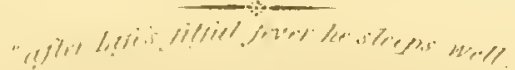

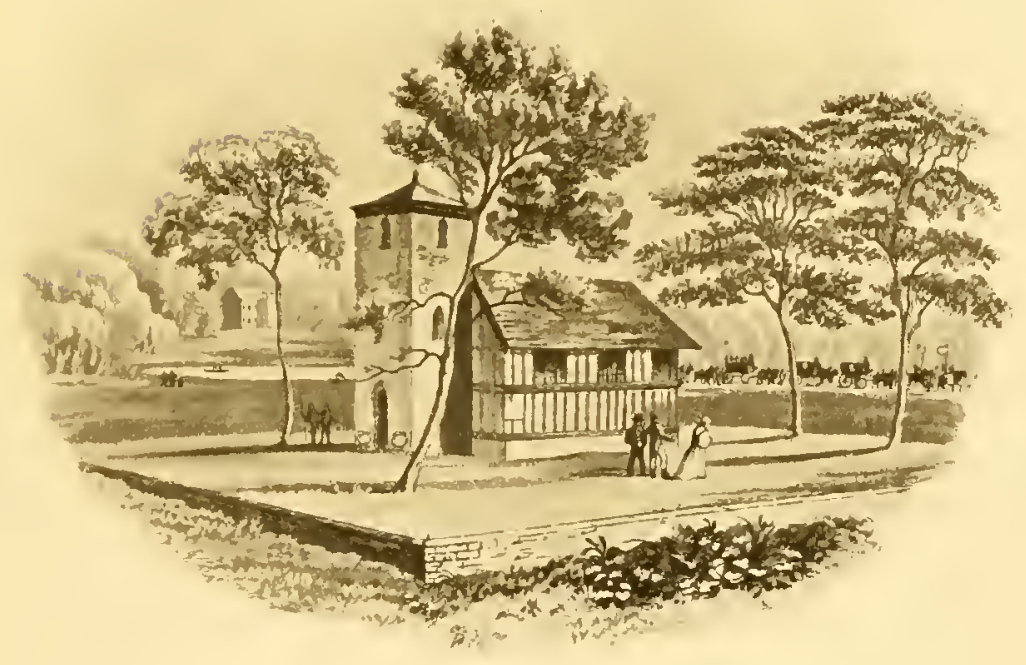

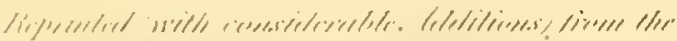

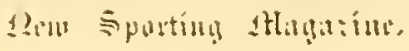

(1) $1,1,1,$. 


$$
\text { 政 }
$$


NOTE ON HENRY ALKEN'S “MYTTON” ILLUSTRATIONS "T HE Memoirs of Jack Mytton," both as regards hero, the far-famed Squire of Halston, as recorded by his biographer, and the spirited pictures drawn by Henry Alken, must be pronounced unique. Probably even the imagination of a sporting novelist would be unequal to the invention of hairbreadth escapes or deeds so utterly reckless as the every-day feats of the dauntless Mytton; and no romances or fictions of the hunting-field as yet given to readers who revel in such moving incidents, afford the sporting delineator equal opportunities for a similar display of his spirited pencil.

The book was there-the hero a living personage, whose daring escapades were familiarly discussed and wondered over amongst his hunting contemporaries, the lovers of sporting adventures. Nimrod himself was the ideal literary hand, by every congenial qualification predestined to chronicle those extraordinary 
performances of which he happened to be an interested eye-witness. This combination happened most happily, it must be allowed. So much for circumstances, which in the first instance led to these dashing "Memoirs" making their appearance in the columns of The Nere Sporting Magazine in the palmy days of sporting literature.*

As is easily understood, Nimrod's stirring narrative was eagerly devoured at the time of publication, and Ackermann, the enterprising publisher, conceived the happy idea of presenting the veracious Memoirs in a form worthy of their sporting character. For this purpose the very man was at hand, and to Apperley, as historian, was added, as artistic collaborateur, the ingenious Henry Alken to furnish illustrations; an unsurpassable combination to which the present work owes its origin. Both artists stand alone, and as yet have found no successors in their respective branches, with the brilliant exception furnished by the later

* "The Life of Mytton" began in October, 1834, in The New Sporting Hagazine, having been announced by Nimrod in the previous number. His letter concluded thus: "I hope you will make a start with poor John Mytton on the ist of October-a melancholy reverse, by the way, of his usual start on that day in the Halston covers. But how true the maxim, 'Nil violentium est perpetumm'-'Tis the pace that kills." 
collaboration of Surtees with John Leech. The original Henry Alken was designing sporting pictures for Ackermann at the date of Mytton's Memoirs; his innumerable productions in this field stand unrivalled, and in our own day are proportionately esteemed by collectors and amateurs whose tastes incline to sporting delineations. Like his literary confrère, Alken was on the spot at the right moment; and never, it may be safely averred, did this genius in sporting illustrations enjoy so tempting a commission, or one more congenial to his special talents.

The publishers of the present extra-illustrated edition of the "Memoirs of the Life of Jack Mytton" have invited me to record a few particulars concerning the "illustrative embellishments," as Ackermann characterised them, when that excellent sporting publisher in the "early Thirties" enlisted the graphic powers of Henry Alken.

The numerous editions treasured by sporting collectors attest the interest these pictures have excited. Nowadays early editions with the amazing handcoloured plates are not only keenly sought after but are rare, and proportionately costly. Alken seems to have designed some twenty leading pictures for the embellishment of Nimrod's narrative; the entire 
gallery is now for the first time published together as a complete series.

Ackermann favoured the sporting public with his first illustrated edition in 1835 ; and the collection proved successful beyond his expectations. The first edition has long been rarissime; it consists of but 1 I 0 printed pages, and contains twelve plates by Henry Alken. So scarce is this version-a thin little volume-that I do not remember to have seen half a dozen copies in a lifetime. Its current value may be estimated at fifteen guineas, though it would not be possible to secure more than a fugitive copy at that figure. The first series of twelve plates were etched by the designer, Henry Alken, and delicately finished in aquatint in imitation of water-colour drawings by another clever artist, E. Duncan. The impressions were issued carefully coloured by hand after the original aquarelles, and are by connoisseurs esteemed highly superior examples of this class of work, the closest facsimiles of the water-colour drawings obtainable by the method of reproduction described. But with all their excellence, they necessarily fail to reproduce exactly those spontaneous and dashing qualities, and the delightful feeling for landscape which were the elder Alken's specialities. 
The popular appreciation which encouraged the publisher's first venture, emboldened Ackermann to follow up this little volume by a more ambitious work, issued two years later. This second edition appeared in 1837 ; the text was printed in bolder type, making a more imposing-looking volume as to bulk, with an engraved pictorial title-page, and embellished with eighteen coloured illustrations. These plates are also, for the most part, after original drawings by Henry Alken, etched by that competent hand, and carefully finished in aquatint by $\mathrm{E}$. Duncan after the originals. As has been mentioned, the firstnamed artist produced in all twenty "Mytton" designs which have come into the writer's possession. Of these some few were executed after suggestions by T. J. Rawlins, as stated on the plates in question, though to all intents and purposes the drawings thus designated are characteristic examples of Alken's special art. Beyond these there were included two designs by T. J. Rawlins, "A Nick, or the nearest way home, with back view of Halston House," and "Heron shooting - A cooler after a big drink!" These plates were etched by Alken with the others, and have thus acquired a share of artistic merit, but the actual designs are commonplace, stiff and poor 
in comparison with Alken's original water-colour drawings, and the present publishers have felt that the above-mentioned pair of plates are uninteresting and spiritless, as lacking the strikingly noteworthy characteristics of the Alken series reproduced in the present edition. The two Rawlins designs were probably merely slight suggestions offered to be worked out by Alken's hand, and as these sketches have not been preserved with the interesting original suite of highly finished water-colour pictures (which became the property of Ackermann in $18_{35}-7$ ), they are accordingly excluded from the present series of facsimiles after Alken; but it is supplemented by a further subject representing one of Mytton's wildest equestrian escapades, putting his horse at a leap down a bank "high as a house." This capital drawing, hitherto unpublished, was evidently designed for the illustration of the first issue.

It may be of interest to notify alterations and modifications as collated from a comparison of the original drawings, herein reproduced, with the twelve plates of the I $\delta_{35}$ first edition, and the eighteen plates of the second edition as published in ${ }_{1} \$_{37}$.

The frontispiece to the earliest edition was " "The Meet,' with Lord Derby's staghounds," applying to 
page 14 of this first version, and given opposite to page 25 of the second edition. Three strongly characteristic plates, which were included amongst the twelve first engraved versions of Alken's "Mytton" Series, are not repeated in the second edition or in subsequent issues. These are restored in the present comprehensive series, reproduced in facsimile direct from the original water-colour drawings. These three subjects are entitled :-

\footnotetext{
Mytton shooting in winter.

Blood and the bull-dog.

Mytton masters the savage dog.
}

Nine of the plates originally given in the first edition were included in the second edition, as is seen from the notes which follow, summarising the illustrations which appeared in the $1 \delta_{35}$ and $18_{37}$ editions respectively. ${ }_{1} \delta_{37}$ edition :-

"The Meet," with Lord Derby's staghounds.

Mytton wild duck shooting.

"What! never upset in a gig?"

A new hunter-"Tally-ho! Tally-ho!"

Stand and deliver.

The Oaks filly.

Light come, light go.

Mytton on "Baronet" clears nine yards of water.

"Damn this hiccup!"

It must be pointed out that two of these earlier plates in the first instance represented the redoubt- 
able hero in a nightcap. Whilst lying out on the ice at night, stalking flocks of wild ducks, Mytton, in addition to his single garment, a shirt, is pictured adorned with a nightcap, and a similar covering appears on his head when setting fire to the aforesaid solitary garment in the plate, showing that mistaken worthy carrying out his novel theory of frightening away that " $\mathrm{d} \longrightarrow \mathrm{d}$ hiccup!" Subsequent knowledge that Mytton was unfamiliar with the use of pockethandkerchiefs and of nightcaps alike, possibly induced the artist to make alterations, and to remove the nightcaps. In the first version of the fatal "hiccup" adventure, an antique "four-poster" is represented in the background; as this tragic incident occurred in France, whither the embarrassed and unfortunate Mytton, who was "broken" in a triple sense-in mind, body, and purse-had sought refuge from his creditors, the antiquated "four-poster" figuring in the earlier plate was, in the second edition, changed into a French bedstead, as a concession to local consistency.

The frontispiece to the second edition and subsequent issues is:-

"Well done, Neck-or-Nothing! You are not a bad one to breed from," as designed after a sketch by T. J. Rawlins, drawn and executed by Henry Alken. 
The remaining "additional plates" which made their first appearance in the $1 \$_{37}$ edition are as follows :-

"1 wonder whether he's a good timber jumper!" A hell of a row in a Hell! Mytton shows fight. Mytton swims the Severn at Uppington Ferry. "He that calls himself a sportsman, let him follow me."

How to cross a country comfortably after dinner.

"A Squire trap, by Jove! A little more and I should have done it!"

"Now for the honour of Shropshire!" The Shavington Day; a trial of rival packs, and consequently of rival horsemen.

There are, moreover, the two designs by Rawlins, already particularised :-

A Nick, or the nearest way home. (With back view of Halston House.)

Heron shooting-" A cooler after a big drink!"

Making up the sum of eighteen plates ( 1837 edition).

So much concerning the rare and costly first and second editions of $1 S_{35}$ and 1837 . I am asked to set down the history of the original drawings, now for the first time reproduced in facsimile, of the actual aquarelles.

Speaking of my own early impressions, these Alken pictures struck my boyhood's fancy as truly wonderful designs, and in their nature sprightly beyond belief. It was in the "late Fifties" that, as a 
youth, I happened to make their first acquaintance amongst the contents of an old-fashioned sporting library, and once seen they are never likely to be forgotten.

Already familiar with the famous aquatinted engravings, the writer, over a quarter of a century ago, was delighted to discover in an Exhibition of Alken's drawings, held in Bond Street, the complete series of water-colour pictures originally designed for the illustration of Mytton's improving Memoirs. Tempting as were these additions to any collection of Alken's works, the value at which the series thus exhibited was estimated seemed prohibitory to a modest purse. Averaging $£ 25$ per drawing, the total came to $£_{500}$, a sum which distinctly chilled the writer's acquisitive propensities. I subsequently discovered that the lucky proprietor happened to be a private gentleman of my acquaintance, who possessed a most extensive collection of sporting pictures, including the largest gathering of Alken's original drawings probably in any collector's possession. These interesting suites, it was understood, had been secured en bloc direct from the successors of the original publishers. The series of "Mytton" drawings constituted the gems of the collection, and, on further visits 
to my friend's residence, my appreciation of the present suite was increased, and the desire of adding them to my little gathering kept pace with this growing admiration.

This acquisitive proclivity was strengthened later on, when the late proprietor, on the occasion of my assisting in forming an extensive Sporting Exhibition, was so obliging as to lend the Alken series of jllustrations to Mytton's Memoirs; and further study of the attractive points of these designs whetted my appetite afresh. On the decease of this worthy sporting amateur his collection was sold for the facility of realising his estate for distribution, and by purchase, the coveted Alken series was added to my sporting treasures of the pictorial order. From the first there was the temptation to reproduce these artistic curiosities by those literal facsimile processes of recent development; but for many years both the drawings and the theory of their ultimate reproduction were left to slumber, while other productions were occupying the writer's efforts. Finally my good friends Messrs. Downey and Co. recognised the uncommon merits of the complete series, and to their enterprise the present volume owes its appearance.

It is the first instance of a sporting work being 
illustrated after this method of reproducing the original drawings by direct facsimile in colours from the original drawings, and it may be questioned whether there is in existence a series of sporting delineations equally spirited, typical, animated, and suitable for the purpose as regards the memoirs of sport, and retrospective aspects of sporting life in the quaint "palmy days of the past."

Joseph Grego. 


\title{
BIBLIOGRAPHICAL NOTE.
}

\author{
First (Collected) Edition, Published in 1835. \\ (Printed pages I Io.)
MEMOIRS OF THE LIFE OF THE LATE JOHN MYTTON, EsQ.

With Twelve Illustrations by Henry ALkEN.

(Plates aquatinted by E. DUnCAN.)

Publisher's Address :

"These Memoirs appeared originally in The New Sporting Magazine, and attracted so much attention at the time of their publication, that the Publisher has been induced to present them to the public in their present form. The illustrative embellishments by ALKEN will, he conceives, add considerably to the interest of the volume."

"The Meet," with Lord Derby's staghounds . . Frontispiece

*Mytton shooting in winter . . . . . . . II

["This plate reas omitted from the second edition and subsequent editions.]

Mytton wild duck shooting . . . . . 12

["In this plate Mytton wears a nightcap: this was removed in second edition.]

"What! never upset in a gig?" . . . . . . 14 
"A new hunter-Tally, ho! Tally lo!" PAGB

Stand and deliver . . . . . . . . . I5

The Oaks filly . . . . . . . . . . 16

*Blood and the bull-dog . . . . . . . 17

["This plate wars anited from the second edtion and subsequent edtions.]

* Mytton masters the savage dog . . . . . . . I 8

[* This phate was omitted from the second edition ant swbsequent edtions.]

"Light come, light go" . . . . . . . 24

Mytton on "Baronet" clears nine yards of water . . 47

"Damn this hiccup!" . . . . . . . 76

[In this forst aersion Mytton is picturet wearing a niwhtcap. In the bucksround the bedstead is represented as an antique "four-poster."]

Second (Enlarged) Edition. Published in 1837.

\section{MEMOIRS OF THE LIFE OF THE LATE JOHN MYTTON, EsQ.}

\section{[IIth engraved pictorial title-page]}

"Numerous Illustrations by H. AlkEN and T. J. Rawlins."

[Containing 9 Plates from the 1835 edition, with 9 additional Plates.] (i 8 Plates aquatinted by E. Duxcan.)

"Well done, Neck-or-Nothing! you are not a bad one to breed from" . . . . . . Frontispiece

[New plate, 1837. Designet after a sketch by T. J. Ruzulins. Drawen and etched by Hen'y Alken.] 
A Nick, or the nearest way home, with the back view of

Halston House . . . . . . . 16

[New Plate, 1837. Designed by T.J. Rawlins. Etched by Henry Alken.]

Mytton wild duck shooting .

[Plate used in 1835 edition. By Henry Alken. In the 1837 edition the artist has removed . Vytton's nightcap (as shown in the $\mathbf{1} 835$ edition).]

"What! never upset in a gig?"

[Plate used in 1835 edition. By Henry Alken.]

"I wonder whether he is a good timber jumper!" . .

"The Meet," with Lord Derby's staghounds

[Plate used in $\mathbf{1} 35$ edition (Fronlispiece). By Henry Alken.]

"Stand and deliver!" . . . . . . . . 26

[Plate used in 1835 edition. By Henry Alken.]

"Tally ho! Tally ho! a new hunter; first then, Tally ho!

Tally ho!" .

[Plate used in 1835 edilion. By Henry Alken.]

The Oaks filly . . . . . . . . 30

[Plate used in 1835 edition. By Henry Alken.]

"Light come, light go" . . . . . . . 42

[Plate uset in 1835 elition. By Henry Alken.]

Mytton on "Baronet" clears nine yards of water $\quad . \quad 82$

[Plate used in 1835 edition. By Henn Alken.]

"Damn this hiccup!" . . . . . . . 127

[Plate used in 1835 edition. By Henry Alken. In the 1837 edition the artist has removed Mytton's nightcap and altered the "four-poster," which figured in the earlier zersion, into a French bedstead.] 
A Hell of a row in a Hell. Mytton shows fight! [Newo plate, 1837. By Henry Alken.]

Mytton swims the Severn at Uppington Ferry. "He that calls himself a sportsman, let him follow me!" . . 188 [New plate, 1837. The drazeing by Henry Alken.]

How to cross a country comfortably after dinner . . . 190 [New plate, 1837. The drawing by Henry Alken.]

Heron shooting :- "A cooler after a big drink !" . . 197 [New flate, 1837. By T. J. Rawlins. Etched by Henry Alken.]

"A Squire trap, by Jove!" cries Mytton. "A little more and I should have done it!" . . . . . $20 \mathbf{I}$ [New flate, 1837. The drawing by Henry Alken.]

"Now for the honour of Shropshire!" The Shavington Day; a trial of rival packs, and consequently of rival horsemen . . . . . . . . . 201 [New flate, 1837. The drawing by Henry Alken.] 


\section{PREFACE}

(TO THE FIRST EDITION).

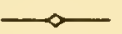

BISHOP BURNET'S narrative of the remarkable passages in the life of the very celebrated Earl of Rochester has been greatly valued, not only as an elegant composition, but as a lesson of instruction to all mankind. The latter of these honours, to a certain extent, I may venture to claim as the result. of this sketch; at all events, such is, in part, its. design; and as no subject is so interesting to man as man, I have a good theme for my pen, inasmuch as. there is one present to my mind whose equal, as a. private English gentleman, the world never before saw; neither is it, for some reasons, desirable the world should ever again see. My only fear is, that I may be deficient in strength of pencil to draw the picture to the life, and to represent the anomaly in human nature which the character of John Mytton presents-at one time, an honour to his nature; at another, a satire on humanity. What more can be done than to strike the balance with an even 
hand? And as the brightness of the sun hides its blemishes, let me hope the greater part of his faults will be lost amidst the virtues with which they are mingled. At all events, my purpose is not to hold up the torch to the failings of my old and neverforsaken friend-my' chicf object bcing to account for them, and leave his virtues to speak for themselves. I owe him pity on the score of human nature; he claims it by his own acts and deeds; and, above all, by one act of $\mathrm{Him}$ to whose will all men must bow, and by whom all men's deeds will be weighed. Let not the lash of censure, then, fall too heavy upon one who himself carried charity to excess! Let the greatness of his fall be unto him as a shield; let it be remembered he died in a prison, an epitome of human misery! A glance over his history, however, may not be unprofitable; it will "point a moral," if it do not "adorn a tale."

But it may be objected that I am not the person fitted to perform this task; for, "Where is the man," says Johnson, "who can confine himself to the exact balance of justice when his own feelings are unwittingly thrown into the scale?" It is true my regard for the late Mr. Mytton was won and secured by many sterling acts of kindness and friendship; and it 
is also true, that friendship is not alaway's the sequel of obligation. I am proud to assert I do not come within this exception; and pledging myself to say nothing that is false, rather than all that is true, I think I can produce these two results :-First, I shall unload the memory of a man I shall never be ashamed to call my friend of several weighty imputations which now rest upon it unjustly; and secondly, I shall show that the boldest efforts of the human imagination cannot much exceed the romance of real life.

NIMROD.

Calais, 1835 . 



\section{CONTENTS.}

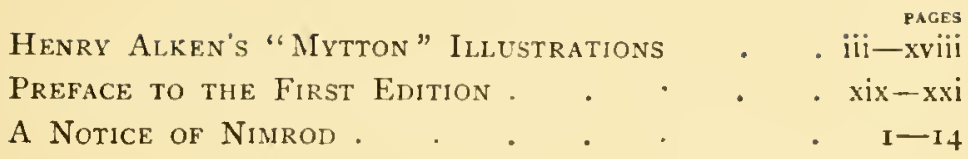

\section{PART I.}

Pedigree of Mr. Mytton-His original name-His contest for the county of Salop-His ancestor Thomas Mitton-Halston described - Extent of Mr. Mytton's property and its various situations-His education, and letter to the Lord Chancellor - Nick-named Nango-Enters the army - II is doings at Calais when in the Seventh Hussars-His first marriage-His sister, her character-His person and mind described-His pugnacious disposition- $\mathrm{H}$ is dress-His method of following wild-fowl-His feats in riding distances on the road, and his walking-His powers of ligestion-His daring exploits, putting his life to hazard-Upsets a friend in a gig - His wonderful escapes in carriages - His indifference to pain-Is taken for a tailor with Lord Derby's hounds-His treatment of a Jew money-lencler-His extraordinary frolics with his chaplain, his doctor, his butler, the bear, a horsedealer, the filly in training, dogs and foxes - An evening at Halston-His contest with a ferocious $\mathrm{dog}-\mathrm{His}$ general character-His reason for selling an old family estate-His establishment at Halston-Amount of his expenditure-His fox-hounds, his racing establishment, his game-preserves, his celiars and his wardrobe--"Light come, light go"-Tricks played by travellers-His gambling-Only one John Mytton - The bill for pheasants-His enjoyment of life-The Halston Chaplain, PP. I $5-76$ 


\section{PAR'T II.}

With whom conpared-His amours - Ilis popularity and its decline - His excessive drinking, and its influence on his character and health - His toilet - His generous conduct towards his mother - His philanthropy-How to hire a servant - His talents - His last contest for the borough of Shrewsbury-The Electioneering Squibs-His politics-His farming-His timber-His planting-As a sportsman-His hounds, and a day with them-As a horseman-His shooting - His racing - His horse Euphrates - His race-cups - His start and progress on the turf - His handsome conduct towards his jockey - His autograph - The Guy Stakes at Warwick-Summary of his racing career-The stables and boxes at Halston-Number of the stakes and plates won by his horses-His second marriage-His conduct in the marriage state-As a lusband and a father, . pp. 77-148

\section{PART III.}

Mr. Mytton's character illustrated by anecdotes - His feats on horseback-His frolics - With waggon-horses - With a bag fox-With rats on the ice-After herons-With a badger -With foxes in the bar of an inn - With "a bagman"With a trainer-With a broken-kneed horse-With a flannel petticoat - With a horse-breaker - With a baker - With a Shrewsbury tradesman-The row at a "hell"-His shooting with a rifle - A cooler after the herons - Extraordinary performances with hounds - Swimming the river SevernTandem-driving by moonlight - In a gig with NimrodHis gig carried over the lodge gate-A parallel instance at Wrexham - "Tom Leigh," of High Leigh, Cheshire - The sale catalogue-The Shavington Day; "Now for the honour of Shropshire!". . . . . . Pp. 1.19-176 


\section{PART IV.}

The breaking up of his establishment at Halston-His arrival in Calais, and his extraorlinary proceedings there-How to frighten away the hiccup-His mind becomes disordered by his sufferings-Extraordinary scenes witnessed by his attendants-Drinks eau-de-cologne-Gets better, and goes into the country with Nimrod-Recovers his health, but soon relapses - Is removed to England-Visits Halston - Thrown into Shrewsbury Gaol-His conduct there, and his former relation to the gaoler-Removed to the King's Bench-Release, and return to Calais--His conduct there-Goes back to EnglandHis death in the Bench-His funeral-His will- "Another" John Mytton, . - . . . . pp. 177-234 


\section{LIST OF PLATES.}

PAGE MTTON TAKES A DROP "AS IIIGH AS A HOUSE" " Frontispiece MYTTON SHOOTING IN WINTER • • • • • • 33 MY'TTON WILD DUCK SHOOTING . . . . . . . 35

"What! Never UPSET IN A Gig?". . . . . . 37

"I WONDER WHETHER HE IS A GOOD TIMBER-JUMPER!" • 39

THE "MEeT" WITH LORD Derev'S STaghounds • • - 4 I

"STAND AND DEliver". • . . . . . . . 4 43

"TALLY-HO! TALLY'HO! A NEW HUNTER; FIRST THEN, TALLY-HO! TALLY HO!" . . . . . . . 45

THE OAKS FILLY • • • • • • • • • • 49

BLOOD AND THE BULL-DOG • • • • • • • • 5 I

MYTTON MASTERS THE SAVAGE DOG • . . . . . 53

"Light CONE, LIGHT GO!" . . . . . . . . 63

MYTTON ON "BARONET" CLEARS NINE VARDS OF WATER - III

A H-LL OF A ROW IN A HELL-MYTTON ShOWS FIGHT. • i6I

"WELl DONE, NECK-OK-NOTHING! YOU ARE NOT A BAD ONE TO EREED FROM" . . . . . . . 163

Mytton swims the Severn at Uppington Ferry. "He THAT CALLS HIMSELF A SPORTSMAN, LET HIM FOLLOW $\mathrm{ME}$ !" . . . . . . . . . . . I65

Ifow TO CROSS A COUNTRY CONFORTALLY AFTER DINNEK - I67

"NOW FOR THE hONOUR OF SHROPSHIRE !" ThE SHaVington DAY; A TRIAL OF RIVAL PACKS, AND CONSEQUENTLY OF RIVAL HORSEMEN • • • • • • • • 175

"A Squire-trap, by Jove!" cries Mytton, "A little MORE AND I SHOULD HAVE JHONE IT!" . . . . I77

"D-N THIS HICCUP!" . . . . . . . 185 


\section{A \\ NOTICE OF NIMROD.}

B OSIVELL could never have written the "Life of Johnson" but for the long intimacy he had enjoyed with his hero; and the same might be said of Nimrod and his "Life of John Mytton." But the parallel can be continued no further. Boswell methodically prepared himself for his work from his first interview with the subject of it, whereas Nimrod and Mr. Mytton lived for years on terms of friendship without the least probability of one ever becoming the biographer of the other. In the common course of events, indeed, the Halston Squire, as much the younger man, should have outlived his companion; while it was only at a comparatively late period in his career that Mr. Apperley ever engaged himself upon literary pursuits.

No man however, could have been more thoroughly 
educated up to the position he was destined to occupy than Charles James Apperley. He was the second son of one Mr. Thomas Apperley, a gentleman of good Herefordshire family, who, from his attainments as a scholar, had been selected as tutor to the Sir Watkin Wynn of that time, and hence his eventually settling at Plâs-gronow, in the county of Denbigh, where Nimrod was born in $177 \mathrm{~S}$. Noticeably enough, the father enjoyed some literary repute, as he was the author of a book of "Moral Essays "which would appear to have been very favourably received. As his son said of him-" he corresponded with Doctor Johnson, read Greek before breakfast, and, being himself a scholar, he fondly hoped he should have made one of me; but in the weakness of his affection, being unable to say 'no,' his hopes were blasted. He suffered me to follow fox-hounds in a red coat and cap, like puss in boots, before I was twelve years old." There is no doubt, though, that young Apperley was well grounded at home both as a scholar and as a sportsman, and in due course he proceeded to Rugby, where his own natural taste for the classics was further developed, with all proportionate profit hereafter. But there was some "devil" in the boy, and, as Sir Richard Puleston said of him and another lad, as they 
rode up to the cover-side, after having been very riotous on the previous evening in the servants' hall of a neighbouring gentleman, "They are a nice couple; at all events they seem to enter well."

On leaving Rugby young Apperley received a commission in Sir Watkin Wynn's Fencible Cavalry regiment, called the Ancient British Light Dragoons, but known in Ireland, where he joined, as "the bloody Britons," from the active part they took in crushing the Rebellion of i 798. "The severity of the losses of the 'Ancient British' may be judged of by the simple fact of my having been gazetted youngest cornet on the rst of April, i798, and becoming nearly senior lieutenant in little more than a year and a half ;" and he was paymaster to the regiment at the time it was disbanded. A year or two after this $\mathrm{Mr}$. Apperley married Miss Wynn, a cousin of Sir Watkin's, and a daughter of Mr. Wynn, of Peniarth, once M.P. for the county of Caernarvon; and in ISOI he took a house at Hinkley, in Leicestershire. The Quorn was then in its glory; the renowned $\mathrm{Mr}$. Meynell had just given up the hounds, but Apperley met him in the field, and no man ever did the thing in better style than his successor Lord Sefton, who built the famous "long stable," had two packs of 
hounds and two huntsmen, and gave greater prices for his horses than had ever been known. During the three seasons the young Welshman spent at the little town of Hinkley, he gathered an almost invaluable store of information. Nor was his next cast a bad one,--when he moved to Bilton Hall in Warwickshire, which, until very recently, had been the property, in right of his wife, of Addison the immortal essayist. Here Mr. Apperley formed that style which subsequently gave so great a charm to his writings; following, as he has recorded it, Doctor Johnson's advice, who recommends those "who would attain an English style-familiar but not coarse, and elegant but not ostentatious-to give their days and nights to the volumes of Addison." But Bilton had other points in its favour, at least in the eyes of the new tenant. It was within reach, although often "a long reach," of four of the most renowned packs of fox-hounds of the day,-the Quorn, the Pytchley with John Warde then at their head, Sir Thomas Mostyn's (afterwards Mr. Drake's country in Oxfordshire), and $\mathrm{Mr}$. Corbet's in Warwickshire. He was a member of the Stratford-on-Avon Club, and for many consecutive seasons had, in addition to those at Stratford-on-Avon, horses at Chapel House near Woodstock, and also at 
Middleton Stony near Bicester, with the object of hunting with the Duke of Beaufort as well as the other packs already named. Of course he had to ride great distances, "to gallop often through the darkness of a winter's night over twenty miles on a very indifferent road, to a bed ordered at Banbury;" and on one particular morning he rode fifty-one miles on two hacks, to meet Sir Thomas and give a greeting to Griff. Lloyd. From Warwickshire Mr. Apperley went to Bitterley Court in Shropshire, and while there joined his friend Colonel Gould as Captain in the Nottingham Militia. In 1817 he was living at Breewood in Staffordshire, and, coming on to London, conceived, under the pressure of some pecuniary difficulties, the idea of writing a book.

During this period, however, it should be said that Mr. Apperley had been qualifying himself for such a work in other ways. He was in good practice as a gentleman jockey, was a member of the Kingscote Club, and had now and then a horse in trainingVictorine amongst others. Then, he knew most of the coachmen on the road, and when he got on the mail he generally drove it; but he never was "master of a greyhound in my life," had an invincible dislike to the rising fashion of battue shooting, and, though 
he once promised to write a paper on fishing, he never carried out his threat. The book upon hunting proposal was favourably received by Mr. Colburn, the publisher, but " no sooner was I in Regent Street, on the road to my hotel, than my course was at once changed. I chanced to meet a very old friend and brother sportsman, to whom I communicated my intentions, together with the result of my interview with Mr. Colburn, when the following parley took place :-

"My Friend. You are wrong in thinking of writing a book. Go to the 'Sporting Magazine ;' it will answer your purpose mich better.

"Mysclf. The 'Sporting Magazine'! That will never do; it is a mere Cockney concern, and no gontleman writes for it.

"My Friend. Never mind that. Take my advice, and go to the proprietor of it. If you write for it, other gentlemen and sportsmen will soon do so also.

"These words were prophetic."

The friend was the father of the writer of this notice. Sporting literature was at that time at a very low ebb-if, indeed, in any way recognised; and beyond Beckford's "Thoughts on Hunting" and 
Daniel's "Rural Sports," there was hardly a work of any repute to turn to ; while the "Sporting Magazine" was certainly "a very Cockney concern." But Apperley braved it, and the first letter, bearing the signature of "Nimrod," appeared in the New Year's. number of $18_{22}$. It was upon "Fox-hunting in. Leicestershire," and written just upon twenty seasons. since its author had first hunted in that celebrated county.

The success of these Letters was something extraordinary,-they were so fresh, so genial, so full of anecdote, and so happily combining the tastes of the sportsman, the scholar, and the gentleman. From an unknown work the "Sporting Magazine" became the taik of town and country, and Nimrod's name was in everybody's mouth. The price of the monthly number was raised from two shillings to half-a-crown, with occasional five-shilling parts, and the circulation doubled in less than two years' time from his engagement. A coach on the Southampton Road was called the "Nimrod;" a "Nimrod" newspaper was started; there were Nimrod breeches and Nimrod blacking, and a huntsman christened his son after the mighty hunter. The Letters on Hunting and the Hunting Tours were varied by Papers on the 
Road and the Letters on the Condition of Hunters, where he went for the hard-meat system in preference to the two or three months at grass; and the advantage of his practice is now universally acknowledged, although it met with some opposition in the outset. He began one of his first articles on the Road-he was forty-four years of age when he took to writing-in this way: "A whip has been much oftener in my right hand for the last twenty-five years than a pen ;" and the "Morning Post" spoke in some regret of "a gentleman who appeared to have passed half his life among hounds, horses, and coachmen, and whose style was so excellent that it was a pity it had not been more worthily directed." The Editor of the "Quarterly Review," on the contrary, was quick to appreciate the value of this happy union of power and experience, and he invited Nimrod to become a contributor to that work; but the latter was bound down to the "Sporting Magazine," and it was some years before he could comply with a request that conveyed so high a compliment. Soon after joining the "Magazine," Nimrod, as he was henceforth known, took Beaurepaire House, in Hampshire, where he commenced farming rather extensively. But what with the hunting tours in the winter, and 
going about in the summer, it is no wonder that agriculture did not pay; and the death of Mr. Pittman, the proprietor of the "Sporting Magazine," in December, IS27, tended to bring matters to a crisis. The two had got on capitally together, and Pittman played his trump-card with great spirit, keeping him a good stud of horses, and otherwise behaving very handsomely. A rupture, however, soon followed on his decease, and in two years' time Nimrod was off the "Magazine;" his contributions closing with the "German Tour," which he made in company with Mr. Richard Tattersall and his son. Although fifty years of age, he wasted from eleven stone seven to ten stone three pounds, in order to ride for the Gold Cup at Dobberan, which he won on rather an awkward-tempered horse called Wildfire. Nimrod presented the Cup in his cap and jacket to the Grand-Duchess of Mecklenburg when he was honoured with an invitation to dinner, and before he left the country a facsimile of the Cup for which he had ridden the winner was sent to him. But the best of all the Tours was that through Yorkshire,-there was so much fresh ground to break up, such a deal of "character" to study, and so many good stories to tell. When a ship reached Calcutta, 
Colonel Nesbit, the master of the Calcutta hounds, hastened with others down to the beach to hear the news. "There are new Ministers in," was the first piece of intelligence. "Oh, hang the new Ministry!" said the Colonel; "is Nimrod's Yorkshire Tour out yet?" The only one of Nimrod's family who "took after" him is the present Colonel Apperley, who went out to India as a cadet, and for many years superintended the remount for the cavalry.

The latter part of Nimrod's life was spent in the neighbourhood of Calais, where he resided for upwards of twelve years, having left England somewhere about 1830 . Here he wrote more than ever, although chiefly on his reminiscences and experience,* but still indulging in an occasional trip to the old country. Conspicuous amongst these visits was the Northern Tour-through Scotland-which he made at the instance of his fast friend the late Lord Kintore, and that appeared in the "New Sporting Magazine" a work which he joined soon after it was started. During his exile he also contributed in turn to the "Sporting Review" and the "Sportsman;" amongst his

- Nimrod told the writer, very shortly before his death, that he had hunted with seventy-three or seventy-four different packs of hounds. 
more memorable articles being the "French Tour," the "Life of John Mytton," the "Crack Riders of England," "Hunting Counties and Masters of Hounds," "My Horses," a "Tour in the Midlands," a "Memoir of John Ward," and the "Life of a Sportsman." The last named of these was the only work of fiction Nimrod ever attempted, and this is the fiction of fact, for almost all the incidents embodied in the story occurred either to his friends or himself. Profusely illustrated, it makes a very handsome volume, and indeed nearly all his papers of any length have been republished in a separate form.

Another great hit during Nimrod's banishment, was his engagement with the "Quarterly Review," on which he entered so soon as he was in a position to do so. The appearance of such papers in such a place tended still to increase his reputation, and Nimrod's name became more famous than ever. But the authorship was not for a time known, and the article on the "Chase" was, in the first instance, attributed to Lord Alvanley; though a critic, on running his eye over the "Road," confidently declared, "Either the devil or Nimrod wrote this!" The effect was quite sensational. Country rectors wrote to the Editor in remonstrance; and Bishops in 
encouragement, bidding Mr. Lockhart go on. A leading Meltonian confessed to having gone three times through the run over Leicestershire before he could put down the number; and another reader, fascinated by the description of the race for the Derby, exclaimed, "This fellow dips his pen in magic! for I can hear the horses breathe, and the silk jackets rustle, as they go by me."

Hitherto Nimrod had been regarded as rather a class man; but now they were all at him, and he wrote frequently for "Fraser," for the "New Monthly," the "Encyclopedia Britannica," the "Morning Herald" newspaper, and a variety of other publications. So continually was he engaged, that the inconvenience of living abroad became very great, and he returned with his family to England in the beginning of the year 1 843 . But, as he himself often said, this was only like the hare doubling back to die in her own country, for his decease occurred in Pimlico on the igth of the following May, after only a few days' illness, and in the sixty-fifth year of his age.

As a successful writer on sporting topics Nimrod will always stand alone. He made the most of an opening that can never occur again. He has naturally had his followers, but how many attempts 
at even the hunting tours have broken down! and how many a book has since been built upon his foundations! In some proof of his influence it may be cited that, during the twenty years he wrote, the fortune of one sporting magazine was made, and three others started in opposition, but that within a short period of his decease these all centred again in one proprietorship. The writer of this sketch had the pleasure of knowing him intimately for years, and a more delightful companion was never met with. His works were a reflection of himself-abounding in anecdote and quick observation; his knowledge of men and horses being coupled with a certain simplicity of manner which has been well said to be an attribute of true greatness. He was, moreover, a very handsome man, with a particularly pleasing expression, admirably caught in Maclise's portrait. At an earlier period, just on his advent in life, he has been as happily portrayed by the pen :-

"Nimrod was one of the most fascinating persons 1 ever saw; his figure perfect, light and active, his features handsome, his complexion clear, and glowing with health, contrasted by his dark, closely-curling hair, and eyes that sparkled with arch intelligence and humour; his countenance beaming with good-nature 
and gaiety. He was truly a sumny person; always prompt to oblige and promote the pleasure of his friends; full of harmless fun and humour; much readiness in conversation, with observation of character, and the sort of descriptive power that has since been recognised in his writings."

One of his essential qualifications was, no doubt, this talent to amuse, but Nimrod can take his stand on higher ground. His writings have done much to raise the character of field-sports, and to better the condition of that noble animal the Horse.

H. C. 
THE

\section{I.IFE AND DEATH}

OF

\section{JOHN MYTTON, Esq.}

\section{P A R T I.}

Ubi plura nitent.- HoR.

$\mathrm{IT}^{\mathrm{T}}$ may be unnecessary, perhaps, to go beyond five centuries back for the pedigree of John Mytton. No one, I believe, ever doubted his being quite thoroughbred. In fact, no half-bred one could have done much more than half what he did in the space of his short life ; but, as I have before said of him, "nil violentum, est perpetumm"- "'tis the pace that kills"-and he was no exception to the rule. It having, however, been stated in the newspapers, that he had represented the ancient borough of Shrewsbury in Parliament, I shall merely show that, if the ancient relation of his family to a town of which their ancestors had been 
inhabitants and burgesses upwards of five centuries - in addition to their ample estates in its immediate neighbourhood-still goes for anything, who had a better right to the honour than he had ? Looking back into the history of Shrewsbury, we find the borough to have been thus represented:-

A.D. 1373 (reign of Edward III.) Reginold de Mutton (Mutton was the original name) and Richard de Pontesbury, members.

I377. Reginold de Mutton and William de Longenolne, members.

1472. Thomas Mutton and John Hord, members.

1491. William Mutton and Lawrence Hoyser, members.

1520. Edmund Cole and Adam Mutton, members.

1529. Adam Mutton and Robert Dudley, members.

1554. Thomas Mytton (now first so called) and Nicholas Purcell, members.

1690. Richard Mytton and Hon. Andrew Newport, members.

I698. Richard Mytton and John Kynaston, members. I 701. Ditto ditto ditto.

1 702. Ditto

ditto ditto.

1 705. Ditto ditto ditto. 
1710. Richard Mytton and Edward Cresset, Esq., members.*

1734. John Mytton, grandfather to the subject of this memoir, stood a stvere contest for the Borough, but was defeated by Sir Richard Corbet, Bart., and William Kynaston, Esq. ; and the late John Mytton, Esq., was elected member January 14, I8I9, having been opposed by Panton Corbet, Esq., who soon resigned the contest. Numbers - Mytton, ${ }_{3} S_{4}$; Corbet, 287.

In so highly an aristocratic county as Shropshire, and one celebrated for its electioneering contentions, these extracts may be sufficient to exhibit the parliamentary pretensions of this ancient family, and of my departed friend.

In I4So, Thomas Mytton was high sheriff for Shropshire, and apprehended the Duke of Buckingham, who had rebelled against Richard the Third, and conducted him to Salisbury, where, as his.

* This election was the result of a very severe contest. The following was the final state of the poll :-Mytton, 224; Edward Cresset (ancestor of Cresset Pelham, Esq., late M.P. for the county), 222; Thomas Jones (ancestor of Sir Tyrwhitt Jones, Bart.), 177 ; Sir Edward Leighton, Bart., I3I. 
historian relates, he was instantly tried, condemned, and executed, according to the summary method practised in those ages. His reward for this very important service is recorded in the Harleian MSS., No. 433; in which is an abstract of the Letters Patent, whereby "King Richard the Third grants to his trusty and well-beloved Squire, Thomas Mytton, and to his heirs male, the Castle and Lordship of Cawes, and all appurtenances thereto, amounting to the value of fifty pounds, and late belonging to our rebel and traitor, the late Duke of Buckingham." This Thomas Mytton married one of the daughters of Sir John Burgh, and was an immediate ancestor of the subject of this memoir.

As has been shown, the first conspicuous ancestor of this family was Reginold de Mutton, of Weston Lizard, Shropshire, now represented through the Wilbrahams and Newports, by the present Earl of Bradford; and it is in 1549 that we first find it seated at Halston, when Sir Robert Townsend is stated to have rented Mr. Mytton's large mansion at Cotow, he - Mr Mytton-having removed to his more recent purchase at Halston, or, as it was then called, Holy Stone, much celebrated in history as the scene of bloody deeds in the reign of the first Richard. At 
this ancient mansion there was a preceptory of Knights Templars, and afterwards of the Knights Hospitallers, under a grant from Queen Elizabeth (who confirmed the alienation of the property from the Knights of St. John of Jerusalem, to whom it was given by an Earl of Arundel who possessed it after the Norman conquest), when purchased, or rather exchanged for, by Edward Mytton of Habberley. There was also formerly an abbey in the village of Halston, taken down more than a century ago; but there is the church or chapel of Halston now standing on the domain, exempt from episcopal jurisdiction, and without any other revenue than what the chaplain may be allowed by the owner of it.

Having described ancient, I proceed to modern Halston; and, unless very fastidious indeed, my readers will agree with me in thinking that it ought to satisfy the desires of every moderate man. In the first place, its location is good. Away from any great road, it is within easy reach of twothe London and Holyhead, and the Shrewsbury and Chester-without being subjected to the inconvenience of either; and the lodge gates open upon an excellent cross turnpike-road, leading from 
Oswestry* to Ellesmere-distant three miles from the former town and five from the latter. Being situated on a flat, the domain is deprived of some of the advantages the extremely beautiful country by which it is surrounded affords, but still the tout enscmble is good. In the front of the mansion is a lawn, of about sixty acres of prettily diversified grass-land, and behind it is a tastily-laid-out flowergarden, contiguous to a fine tract of meadow land, separated from it by a deeply sunken fence; and a noble sheet of water, with the old family chapel at the head of it, gives a good finish to the landscape. When I say that the oak is the weed of that part of our island, I scarcely need add that, in a domain of such antiquity as Halston, it isI fear I must write was-to be seen in its full majesty of form; and no estate in the county could produce finer oaks than those which adorned the Halston woods. I can, indeed, speak to the fact of one which was cut down, about eight years back, containing ten tons of timber, without top or

- There is now, of course, a railway running lhrough Oswestry. which is a first-class station on the Welsh Coast line. 
lop! The plantations, also, all made by Mr. Mytton, and to the extent of three miles, nearly encircle the domain, and afforded shelter to the superfluity of game which it was his ambition to possess.

The mansion-house, without pretensions to magnificence, is replete with every confort and convenience for a country gentleman's establishment; and is much more commodious than it appears to be, from the offices being for the most part detached. It contains a hall, in which there was a billiardtable, with a library on one side and Mr. Mytton's dressing-room on the other; and an excellent dining and two drawing-rooms, connected with each other by double doors, complete the downstairs suite. There also was-oh! I write that word with sorrow - a small but excellent collection of pictures, which the catalogue of them showed had been collected with great care, as ornaments to these, now naked, walls; and a thousand guineas were offered, in my presence, for one of them,* but nobly refused by the owner of it. The gardens are most excellent, and, to complete the sketch of this, to me, sort of earthly paradise, there is in the grounds surrounding the

* "Joseph Escaping from Potiphar's Wife." 
house, not only a rookery, but a heronry-very rare in that part of the world, and every description of shooting and fishing that the follower of such sports could require. The surrounding country is also quite upon a par with the "provincials"-if not better than most-for either fox-hounds or harriers.

The property of Mr. Mytton has been a good deal exaggerated, both as regards the annual value of his estates, and the sum accumulated in his minority, which was to the extent of seventeen years. I have grood reason to believe that the former (though it increased afterwards) was under ten thousand a year, and that the latter amounted to about $60,000 \%$ Independently of the Halston and Habberly estates, which are in entail, there were three other properties in Shropshire, and one in North Wales of about Sool. per annum, with a manor and right of free warren,-each very rare in the Principality, and the latter very rare everywhere; but alas! they are lost in the general wreck. The Welsh domain will be described when I touch on the subject of shooting.

Having done with the mansion, we will now proceed to the proprietor of it, who, being born on the 3 oth of Sept. I 796, was left fatherless before he was two years old; and, as if there was a disposition 
in his predecessors to drop into an early grave, neither his great-grandfather nor his grandfather lived to see a son come of age. As I can only just remember the father of Mr. Mytton, I am unable to estimate, in this individual instance, the loss of a father to a son in his infant state; but in most cases, with heirs to large estates, it is irreparable. It is written of the Gracchi that they were educated "non tam in gremio quem in sermone matris;"* and, although it is not every mother that is a Sempronia, their history informs us they were: very little the better for it, if not a great deal the worse. We cannot marvel at this. When the plant: is young and tender, a gentle force will inclineit to whichsoever way we may wish, but ere it has. even attained its full growth it very unwillingly bends. to our hand; and thus it is with human kind. The excessive tenderness of a fond mother is no match for the wayward temper of a darling boy, and how often is his ruin to be traced to this source! In the weakness of her affection she is unable to say "No;" and she only finds out when it is too late,

- It is difficult to render this passage literally; but it implies that the Gracchi were not only nursed, but in part educated, by thein notlier. 
that the object of her affection will neither bridle his passions nor restrain his actions at her bidding; nor indeed, as was unfortunately the case with the memorable subject of this memoir, at that of any other human being. But was not such always the case? The Lacedamonian lawgiver, at all events, was of this opinion, when he ordered the two hounds to be brought into court to illustrate his argument in favour of moral restraint. One took after a hare, and the other ran to his dinner, as each had in his youth been instructed to do. "There," said the Spartan, "is the effect of early discipline; those animals were whelps of the same litter, but the difference of education has made one a good hound, that seldom misses his game, whereas his brother is a cur, fit for nothing but to lick the dishes." And thus it is in the stable.

\footnotetext{
"Fingit equum tenerâ docilem cervice magister Ire viam, quam monstrat eques,"-
}

writes Horace, when he shows that the temper of the horse depends upon his treatment when a colt.

It is scarcely necessary for me to observe that, before he was ten years old, Master Mytton was as finished a Pickle as the fondest mother and his own 
will could possibly have made him. Indeed his neighbour, Sir Richard Puleston, with a felicity of expression peculiarly his own, christened him Mango, the king of the Pickles, and he proved his title to the honour even to the end of his life. But Master Mytton was withal a wonderful favourite in his neighbourhood, because all his actions were tempered with kindness, as indeed they were to his very last hour. But how am I to describe the whole career of his infant state, his scholastic progress, and his academical honours? Why the task is performed in a few words. He was expelled Westminster * and Harrow; knocked down his private tutor in Berkshire, in whose hands he was afterwards placed; was entered on the books of both universities, but did not matriculate at either, and the only outward and visible sign of his ever intending to do so, was his ordering three pipes of port wine to be sent addressed to him at Cambridge. At the age of eighteen, however, he went a tour on the Continent by way of some-

* Here he spent 800 l. a year, exactly double his allowance. In some proof of how utterly inadequate this was, it may be mentioned that he wrote to Lord Eldon, as Lord Chancellor, requesting an increase of income, as he was going to be married-being about fourteen years of age at the time! The reply of his lesal guardian was sufficiently laconic:-" Sir, if you cannot live on your allowance, you may starve; and if you marry I will commit you to prison." 
thing like "the finish;" and then returned to Halston, and his harriers, which he had kept when he was a child.

But we will now look on him when a man! As the proud recollections of the Roman fathers often disturbed the dreams of their sons, it is possible that our hero, although I never heard him speak of him, miglit lave cherished the recollection of the renowned General Mytton, and wished to signalise himself, as he had done, in arms. Be this as it may, at the age of nineteen, he entered, as a Cornet, the 7 th Hussars, and joined them in France with the army of occupation. But as by this time all fighting was at an end, Cornet Mytton made himself signal in sundry other ways. A heavy purse and an open hand are by no means necessary qualifications in a soldier; and it was very unlikely that he, above all men, having only a few months to wait for being in full possession of his property, should keep without the magic circle, and not cnter into ail kinds of youthful mischief. Some of his feats were of a nearly harmless nature, such as his racing exploits-limself the jockey; his borrowing 3000 . of a banker at St. Omer one day, and losing half of it the next at 
a rascally $E$. O. table, which he demolished to atoms as some satisfaction for his loss; but his doings at Calais at this period were of a more serious nature. He lost the immense sum of sixteen thousand Napoleons to a certain Captain, at billiards, which sum he could not then pay. But the score was wiped off in a more agreeable manner. It being suspected to have been a cross, which no doubt it was, the Colonel of his regiment, the late Marquess of Anglesea, then Earl of Uxbridge, forbade his paying the money; and with any other man but John Mytton, such authority would have been conclusive. He, however, afterwards entered into correspondence with his opponent which led to the publication of pamphlets and placards; but a later transaction, in wlich that person's conduct was implicated, proved how right Lord Anglesea was in his decision, and how wrong the victim was in ever holding a communication with his destroyer.

Quitting the army, and in his twenty-third year, he entered for the first time into the marriage state, and his wedding was thus announced in the Shrewsbury papers :-

"On the 2ist May, 18I8, at St. George's, Han- 
over Square, by the Rev. William Douglas, Prebend of Westminster, John Mytton, of Halston, in this county, Esq., to Harriet Emma Jones, eldest daughter of the late Sir Tyrwhitt Jones, Bart., of Stanley Hall, in this county, and sister to the present Sir Tyrwhitt Jones, Bart. The bridegroom was attended by the Earl of Uxbridge, the Earl of Denbigh, Sir Watkin Williams Wynn, Bart., Colonel Sir Edward Kerrison, \&c., \&c. After the ceremony they returned to the house of Lady Jones, in New Norfolk Street, where a most elegant breakfast was provided; and from thence the happy couple immediately left London for the seat of the Duke of Marlborough at Blenheim. Among the company present were the Duchess of Marlborough and Lady Caroline Churchill, Sir John and Lady Dashwood and Miss Dashwood, Sir Edward and Lady Kerrison, Lord and Lady Say and Sele and Miss Twisleton, General and Mrs. Gascoyne and Miss Gascoyne, the Marquess of Blandford and Lord Charles Churchill, Mr., Mrs., and Miss Leigh, Sir Tyrwhitt Jones, Mr. and Mrs. Patton Bold and the Misses Bold, and many other persons of distinction."

The issue of this marriage was only one daughter, who for some time resided with Mrs. Corbet, of 
Sundorne Castle, Shropshire, widow of the ever-to. be-revered John Corbet, who so many years hunted Warwickshire. Mrs. Mytton, whose state of health was always delicate, died a few years after her marriage. Mr. Mytton had but one sister, who was married to the present Sir John Hesketh Lethbridge, Bart., then an eldest son, in March, I8I7, and she ceased to exist in the same month of the year 1826 , leaving two sons and four daughters. She was not only truly elegant in her person, but very highly accomplished, and of a singularly mild and amiable disposition; and those who wish for a confirmation of the eulogium I have passed upon her, may satisfy themselves by referring to the Gentleman's Magazine for October I826, page 357; where her character is very faithfully sketched in some lines from the pen of a female friend, a niece to the present Bishop of Norwich. Mytton had a great respect for this amiable sister, but would never take her advice, nor indeed that of any living soul.

Both in person and in mind the gifts of nature were amply bestowed upon Mr. Mytton. In fact, he possessed what are called the animal faculties to a degree selfom witnessed; and had he been com- 
monly temperate in his mode of living, he might, bar. ring accidental death, have attained a very advanced age. The biceps muscle of his arm was larger than that of Jackson's, the celebrated pugilist, and those of every other part of his body were equally exuberant and powerful. Unfortunately, however, for himself, and often so for his companions, he was, like Cleanthes of old, proud of displaying his strength; but fortunately for mankind he would not, like Cleanthes, be instructed in the art of boxing, or he would have been still more formidable with his fists. As it was, in a "turn up," he was what is called a very awkward customer, and when he could get at him he knocked down his man as if he had been a nine-pin. But he was nearly ignorant of the science of self-defence, and, as I have already observed, never attempted to attain it. His bull-dog courage, however, added to his tremendous blow, enabled him to beat any ordinary man; and so well was his prowess known, that few ventured to encounter him. He had not a handsome face, but by no means an unpleasing countenance; and, without having practised the graces, the air and character of the gentleman were strongly impressed on his carriage. His shoulders were fulely formed, with 
a very expanded chest-height, about five feet nine inches; weight, varying in the last twelve years of his life, from eleven to thirteen stone.

I should think the best battle he ever fought was in 1826 , with a countryman-a Welsh minerwho offended him by holloaing the harriers of $\mathrm{Mr}$. Nicholls, of Crumpwell, near Oswestry, to a fresh hare, when they were on the scent of the hunted one, and on the point of killing her after an extraordinary run. The miner told him he would find him "a tough un," which he did; but after twenty rounds he cried, "Hold hard, enough." And now appears Mytton in his true character. The hunted hare being eventually killed, he gave the miner ten shillings, told him to go to Halston and get "another bellyful," and to order the hare to be cooked for dinner that day.

Never was constitution so murdered as $\mathrm{Mr}$. Mytton's was; for, what but one of adamant could have withstood the shocks, independent of wine, to which it was almost daily exposed? His dress alone would have caused the death of nine hundred of a thousand men who passed one part of the day and night in a state of luxury and warmth. We will take him from the sole of his shoe to 
the crown of his hat. He never wore any but the thimnest and finest silk stockings, with very thin boots or shoes, so that in winter he rarely had dry feet. To flannel he was a stranger since he left off his petticoats. Even his hunting-breeches were without lining; he wore one small waistcoat, always open in the front from about the second of the lower buttons; and about home he was as often without his hat as with one. His winter shooting gear was a light jacket, white linen trousers, without lining or dracuers, of which he knew not the use; and in frost and snow he waded through all water that came in his way. Nor is this all. He would sometimes strip to his shirt to follow wild-fowl in hard weather, and once actually laid himself down on the snow in his shirt only to wait their arrival at dusk. But Dame Nature took offence at this, and chastised him rather severely for his daring. On one occasion, however, he out-heroded Herod, for he followed some ducks "in puris naturalibus"-Anglicè, stark-naked-on the ice,* and escaped with perfect impunity. He was the only man I ever knew who I think, at one time

* This occurred at Woodhouse, the seat of his uncle, who related the story to me in London, the circumstance having occurred since I last visited Shropshire. 



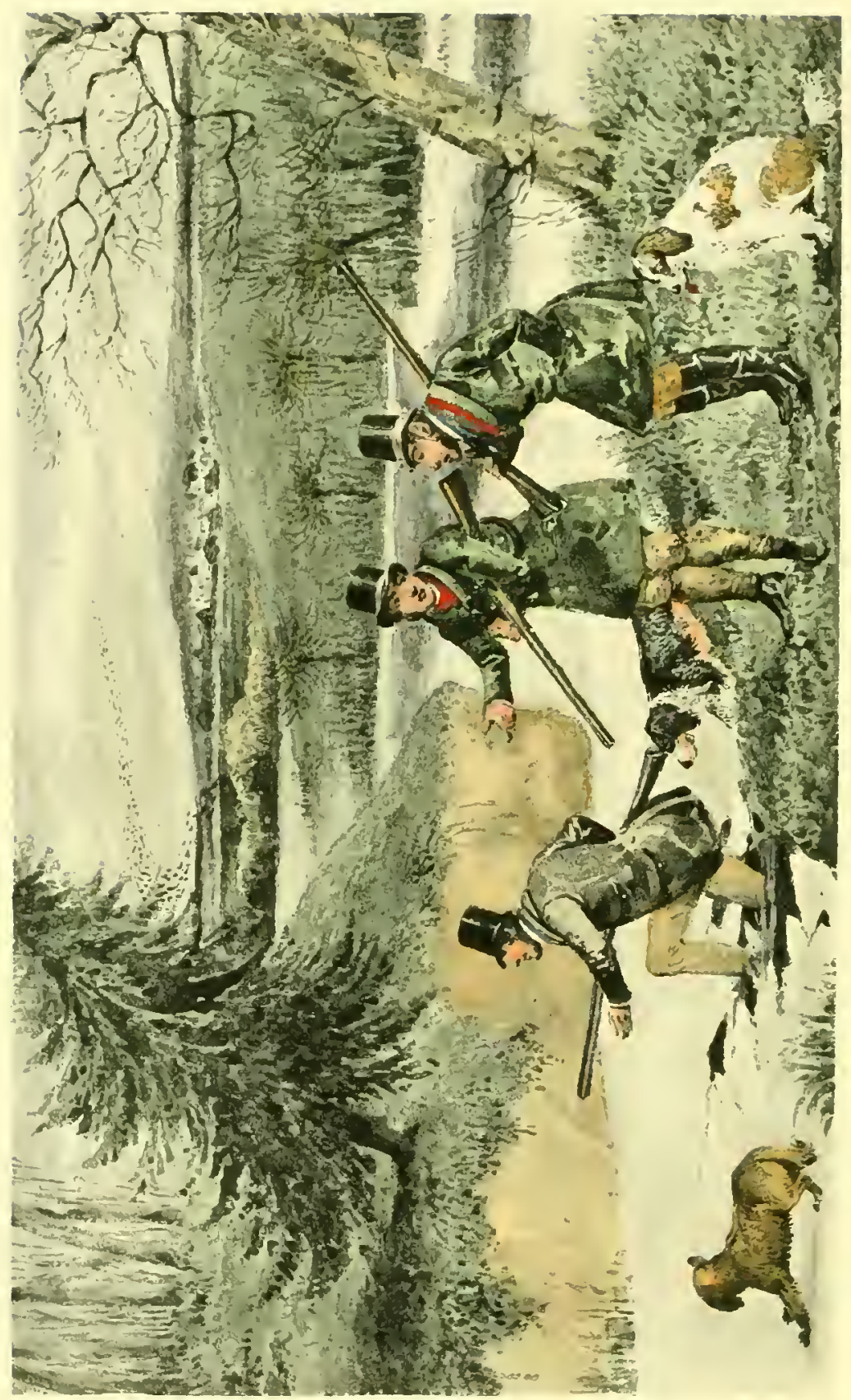




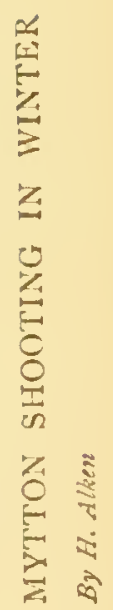


$=$ 
of his life, might have stood some chance of performing the grand Osbaldeston match over Newmarket, from the ease with which he performed immense distances on the road on his hacks. He would ride. several times in the week, to covers nearly fifty miles distant from Halston, and return thither to his dinner. Neither could any man I ever met in the field walk through the day with him at his pace. I saw him, on his own moors in Merionethshire, completely knock up two keepers (who accompanied him alternately), being the whole day bareheaded under a hot sun. (One of these keepers-whom I procured for him in Cheshire-was rather a crack walker, and a noted man with his fist.) He had the stomach of an ostrich before it was debilitated by wine, and even against that it stood nearly proof to the last, but it appears he once met with his match. Himself and a friend left London togrether with eighteen pounds of filbert-nuts in his carriage, and they devoured them all before they arrived at Halston. To use his own words, they sat up to their knees in nut shells. But it was often alarming to witness the quantity of dry nuts he would eat, with the quantity of port wine which he would drink; and on my once telling him, at his own table, that the ill- 
assorted mixture caused the death of a schoolfellow of mine," he carried a dish of filberts into the drawing-room with him, for the purpose of "clearing decks," as he said. Among other peculiarities, he never carried a pocket-handkerchief, for he never had occasion for the use of one; he very rarely wore gloves, for his hands were never cold; and although he never wore a watch, he always knew the hour.

Mr. Mytton was a great favourite with the shopkeepers of Shrewsbury and Oswestry, and among others of a sporting hairdresser at Shrewsbury, to whom he often gave a day's shooting. This man was his chief purveyor of filberts, and having an unlimited order for the purchase of them about the country, declared that, in one season, he sent to Halston as many as two cart-loads of them! As may be supposed, in return for pheasants and hares, the barber's shop was now and then the scene of a "lark." Entering it one evening, Mytton asked what he could have to drink? but before an answer could be given him, he snatched up a bottle of

* When mentioning this fact, I was quite unconscious that General Williams, who was present, was brother to the youth I alluded to. "You are speaking of a brother of mine," said the General. "Volat irrevocabile verbum;" I had nothing left but to apologise. 



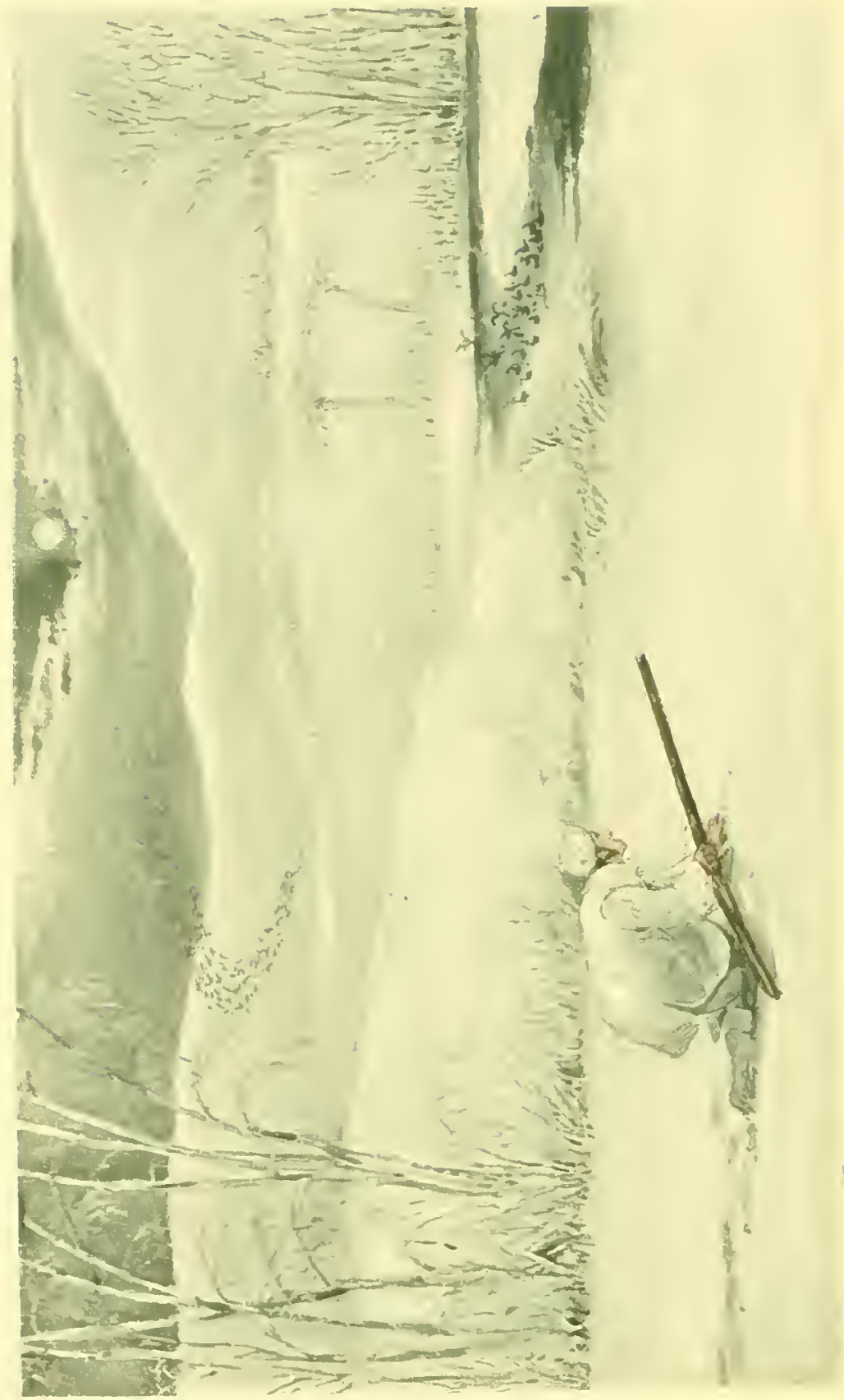




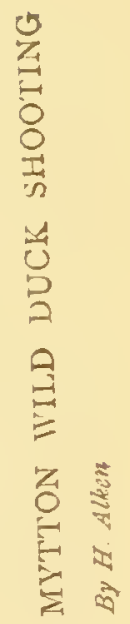



lavender water, and, knocking off the head of it, drank it off at a draught, saying, "It was a good preservative against the bad effects of night air." I shall presently show that this was not his last performance in this way.

That John Mytton saw his thirty-eighth year must be attributed either to the good genius that accompanied him, or to the signal interposition of Providence, for scarcely a day passed over his head in which he did not put his life to the hazard. Some of his escapes, indeed, border closely on the miraculous, but it would fill a volume were I to enumerate them. How often has he been run away with by horses in gigs! How often struggling in deep water, without being able to swim! How was it that he did not get torn to pieces in the countless street-broils in which he was engaged; * and lastly, how did he avoid being shot in a duel? The latter question is soon answered-he ncver fonght one. In fact, he was always considered somewhat of a man of

* In the literal sense of the term, he was once nearly divided into two John Myttons, at a race meeting in Lancashire, for which offence-as well as an attempt to rob him-one man was transported. One party of thieves wanted to pull him into a house, and the other out of it, so between both he was nearer being quartered than divided, and nothing but the great strength of his frame saved him. 
license in society, and although no one doubted his standing fire, if called upon, it is my firm persuasion nothing would have induced him to have aimed at a man to destroy him. In the saddle, too, he ran prodigious risks for his life, not only by ricling at apparently impracticable fences, with hounds, but in falling from his horses when intoxicated. For the former of these acts he was for many years so notorious, that it was a common answer to the question, whether a certain sort of fence could be leaped, or whether any man would attempt it?that it would do for Mytton. And his style of driving was equally remarkable. Whenever the country people saw a carriage or tandem going along at a greater speed than usual, they would cry out, "There goes Mytton!" and run to the road-side to give him a cheer. He once actually galloped at full speed over a rabbit-warren, to try whether or not his horse would fall, which of course he did, and rolled over him. This perfect contempt of danger was truly characteristic of himself; but, not content with the possession of it, he endeavoured to impart it to his friends. As he was one day driving one of them in a gig, who expressed a strong regard for his neck, with a hint that he considered it in 



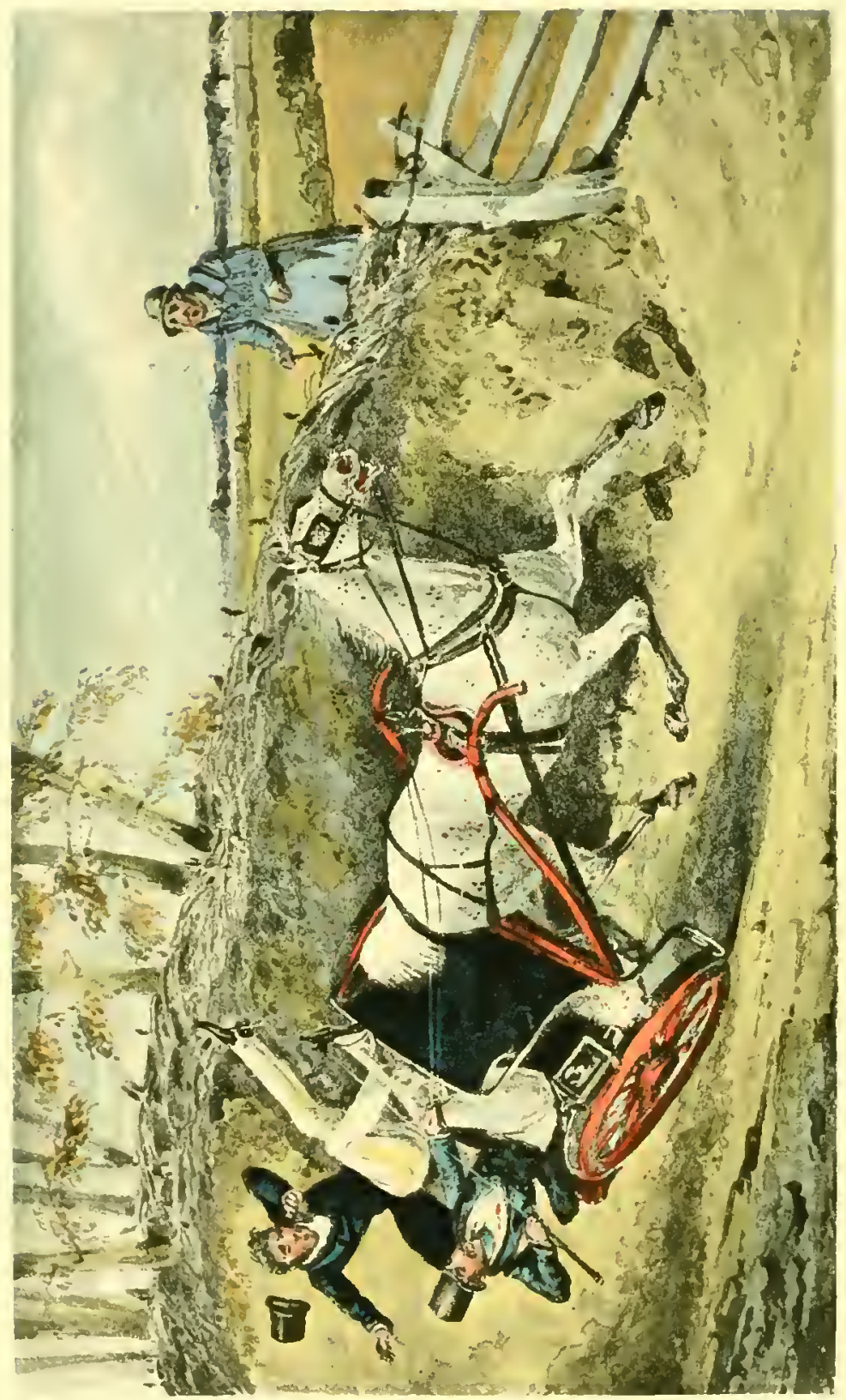




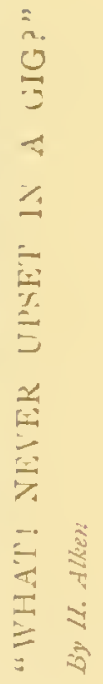


some danger, Mytton addressed him thus :- "Were you ever much hurt, then, by being upset in a gig?" "No, thank God," said his companion, "for I never was upset in one." "What!" replied Mytton; "never upset in a gig? What a $\mathrm{d}-\mathrm{d}$ slow fellow you must have been all your life!" and running his near wheel up the bank, over they both went, fortunately without either being much injured!

Shortly after Mr. Mytton attained his majority, he gave a horse-dealer, named Clarke, of Meole, in Shropshire, an order to purchase for him some carriage-horses. Putting one of them into a gig tandem, to see, as he expressed himself, "whether he would make a good leader," he asked the dealer, who sat beside him, if he thought he wars a good timber-jumper? On the dealer expressing a doubt, Mytton exclaimed, "Then we'll try tim;" and a closed turnpike-gate (at Hanwood) being before him, he gave the horse his head, and a flanker with his whip at the same moment, when he cleared the gate in beautiful style, leaving Mytton and the dealer, and the other horse, all on the nether side of the gate; and fortunately all alive, although the gig was much injured. He once had a horse that 
would rear up in his gig at the word of command, until the hinder part of it absolutely touched the ground; and, although he was much given to display this dangerous accomplishment, no accident was the result.

I was myself once passing through the town of Oswestry, only two hours too late to have witnessed a most singular performance of a team of coachhorses of his, which he had been exercising in a break. Finding they had the better of him, he contrived to quit the carriage without injury, and the horses being at liberty, ran at full speed into the town. Unfortunately a gateway was in their course, into which they dashed, and now for the finish. The said gateway led into a parallel street, but, narrowing as it lengthened, there was, towards the further end of it, room for the horses, but not for the carriage to pass. The consequence was, the four horses, breaking all their harness by the shock, tumbled head over heels into the street, and, strange to say, not one of them was killed.

Perhaps the most extraordinary accident that ever happened to this most extraordinary man was on his return, after dark, from a race-course, in his travelling carriage and four. The postboys mistook an 



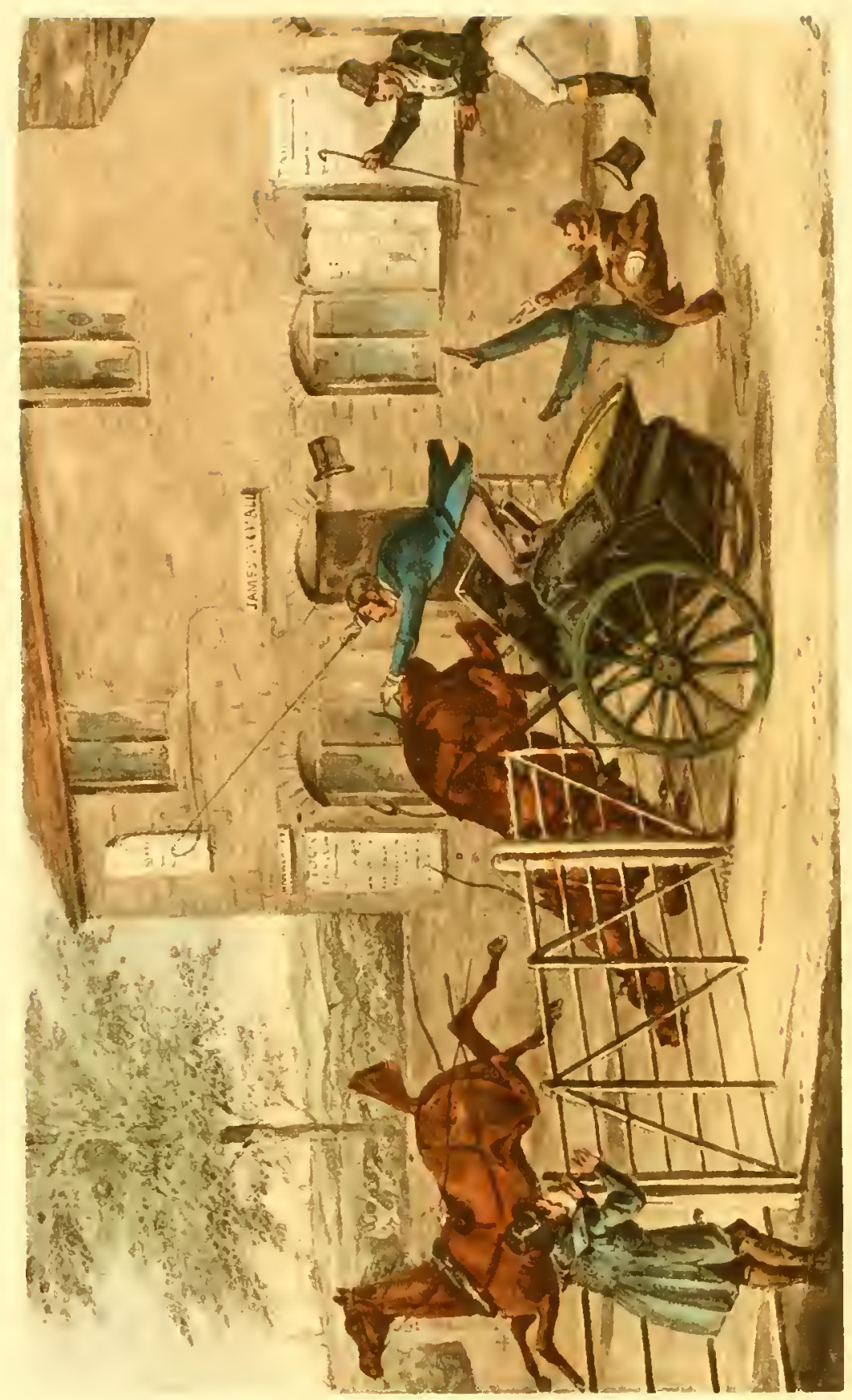




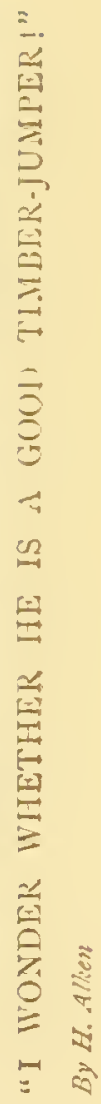



old road, which had been stopped-up, for the right one; and entered it, dorun hill too, at the rate of fourteen miles in the hour, when they came suddenly in contact with some fallen trees, which were placed across it as a barrier. The force of the shock may be imagined; the carriage was broken to pieces; the servant was pitched from his seat to a very considerable distance, sustaining a fracture of the skull from the fall; and Mytton was a goodl deal hurt-any other man, perliaps, would have been killed, as he was fast asleep at the time. The fate of the horses and the boys I do not at this moment recollect; but the servant-who, by good conduct, was promoted by degrees to the post of valet-dechambre to Mr. Mytton from being a boy in my stable-has, I fear, never recovered from the effects of this dire mishap. On another occasion, when I was on a visit at Sir Bellingham Graham's, the night being very dark, the postboy conducted Mytton into a meadow, instead of taking a short turn in the road; and, after driving him around it a great many times without being able to find his way out, he left him in his carriage, whilst he went back to Sir Bellingham's for a lanthorn. As the household were all gone to rest, the Squire of Halston must 
have had a good many turns round the meadow: but, fortmately for the posiboy', he never awoke.

Mr. Mytton appeared, at least wished to be supposed to be, indifferent to pain. A very few days after he had had so bad a fall with his own hounds as to occasion the dislocation of three ribs, and was otherwise much bruised, a friend in Wales, unconscious of his accident, sent him a fox in a bag, with a hint that, if turned out on the morrow, he would be sure to afford sport, as he was only just caught. "To-morrow, then," said Mytton, "will we run him ;" and although he was lifted upon his horse, having his body swathed with rollers, and also writhing with pain, he took the lead of all the field, upon the horse he called "The Devil," and was never headed by any man, till he killed his fox, at the end of a capital hour's run. He was very near fainting from the severity of this trial; but I remember his telling me, he would not have been seen to faint for ten thonsand pounds.

Upon another somewhat similar occasion, he showed his disregard of pain. $\mathrm{He}$ was on his return from the field, with two of his ribs displaced, and evidently suffering much from a fall. To enable him to cut off an angle, he got into a fold- 



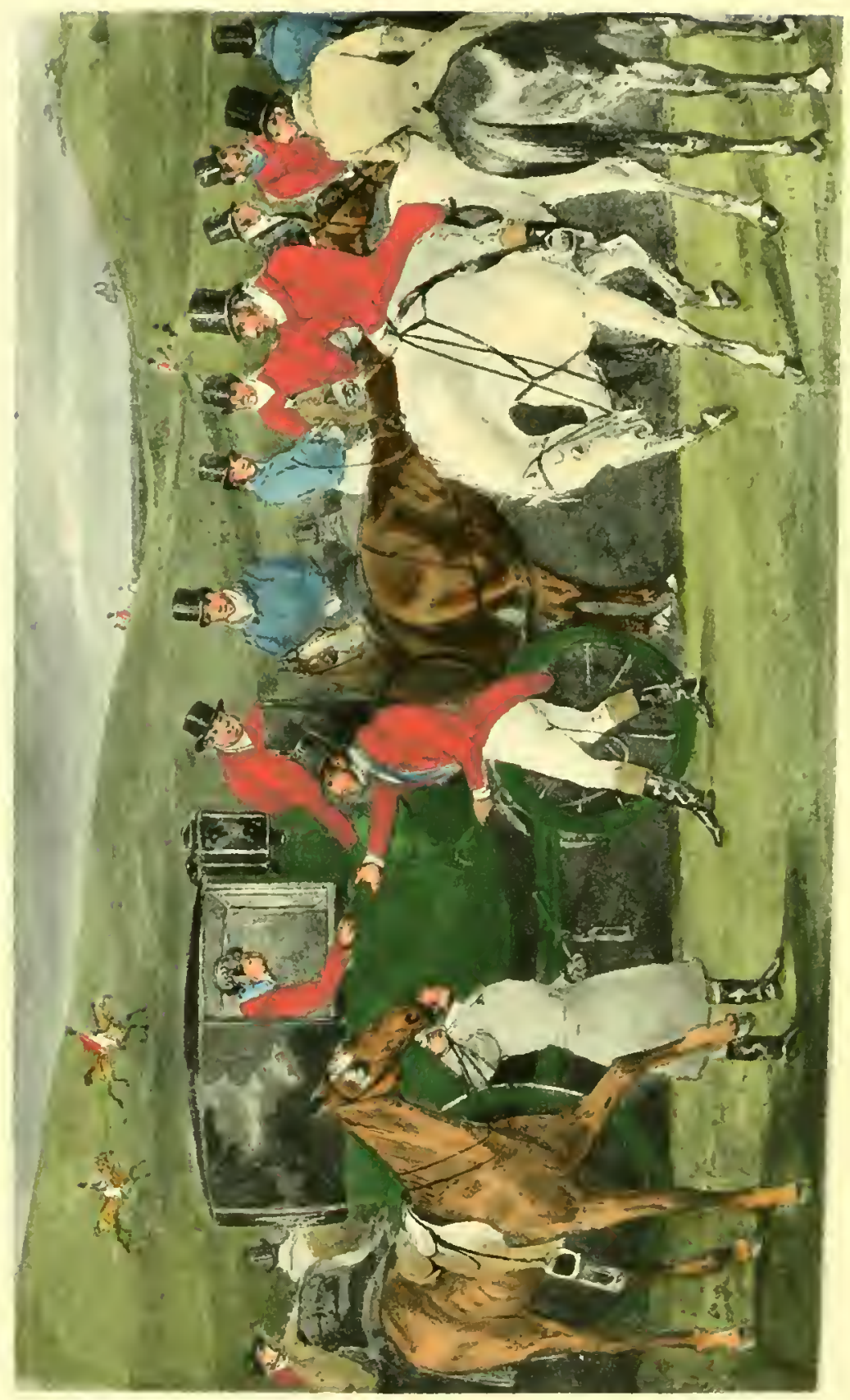




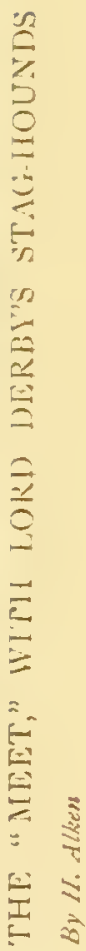


$=$
$=$

$=$
$=$
1
$=$
$=$
$=$
$=$
$=$
$=$
$=$
$=$
$=$ 
yard, but could not get out of it unless by riding over some high rails, which he did, in that state.

In the hilarity of high animal spirits he performed some feats that were ludicrous, and others that were painful to witness. Amongst the former was his appearance with Lord Derby's stag-hounds, when he was taken for a London tailor. Happening to be in town in the hunting season, he had a desire to see those celebrated hounds, and Tilbury sent out a horse for the purpose. On his arrival at the place of meeting in a cab, which he had driven at an awful rate, he attracted the notice of the throng, to all of whom, save one, he was a stranger. "What a buck he is!" said one. "Who the d-1 is he?" said another. "He is a tailor from London," said several, all of which remarks were carefully re-echoed to him by his friend. Mytton said nothing, but the tables were soon turned when Lord Derby's carriage drove up. "What, Mrtron!" exclaimed Lord Stanley, * "who would have thought of seeing you here?"putting out his hand to welcome him. "Why, to tell you the truth, Stanley," said Mytton, "I have ridden over many a good fellow in my own country, 
but I never rode over a Cockney, and I am come here to-day for that sole purpose."

His treatment of a London Jew money-lender was not amiss. Being wearied by delay, he hired two coal-heavers to knock at his door every second hour throughout the night, until the money was forthcoming. But this anecdote furnishes a painful recollection on the subject of moneylending. A few years back he borrowed ten thousand pounds on an annuity at high interest, and lent nine of it to a friend who has never been seen in Europe since! This, although a type of the man, is no matter for joking; but the following may be looked upon as frolics. He had a parson and a doctor dining with him one evening at Halston, and at a certain hour of the night they mounted their horses to return to their homes. Having a carter's frock, and a brace of pistols loaded with blank cartridges, at hand, Mytton mounted a hack, and by a circuitous route headed and met them on the road, when letting fly both barrels at them, and calling to them to "stand and deliver," he declared they never rode half so fast in their lives as they did from that place to Oswestry, with himself at their heels. He once stopped and robbed, on this same road, his own butler, who was 



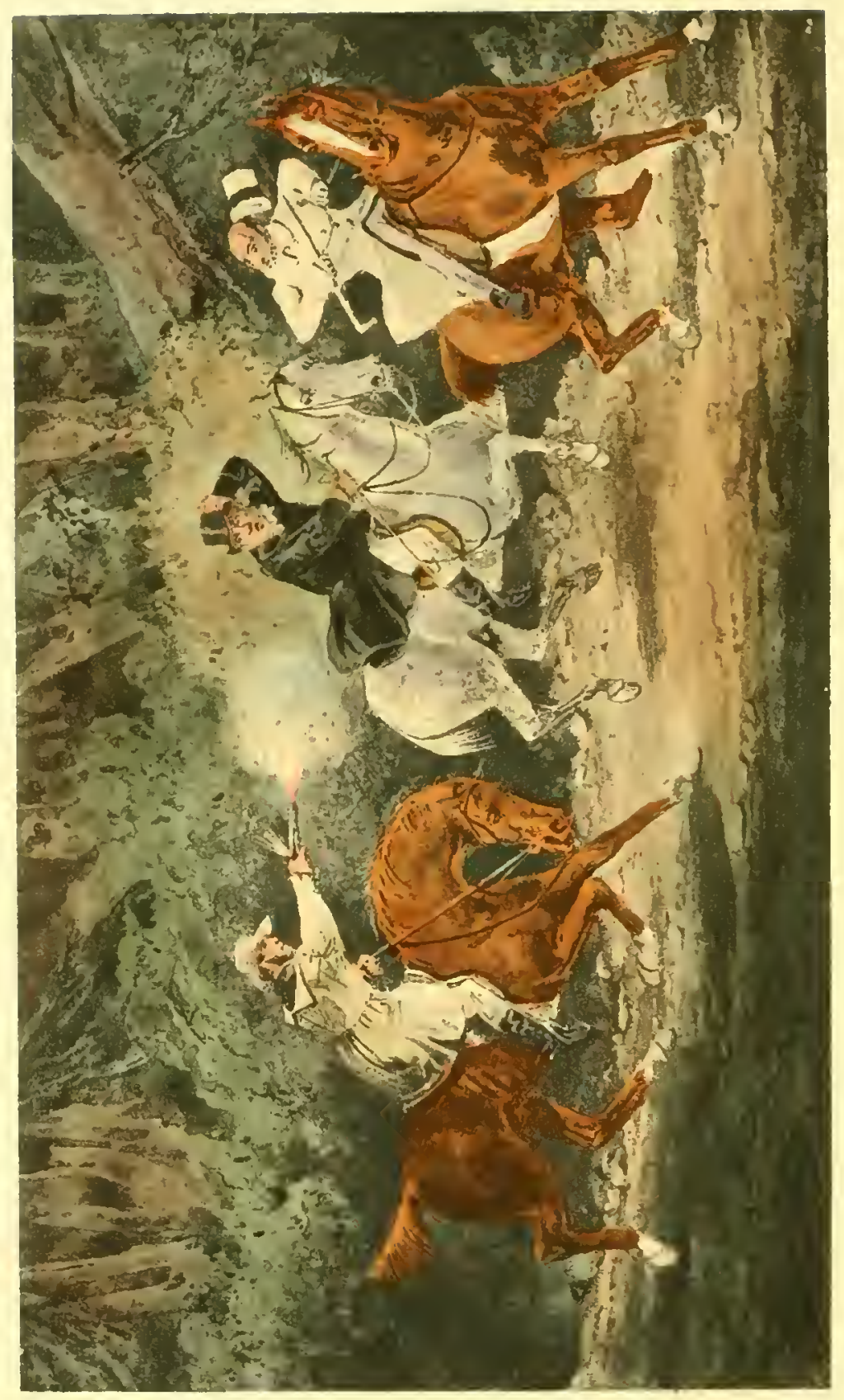




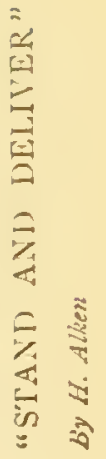



returning from the town with a sum of money he had just received from the agent. The man had boasted that no one should ever rob him; but on Mytton suddenly putting a pistol to his head by the green gates, he meekly gave up both the money and his watch. Mytton was fond of, as well as very good at, disguising himself, in wlich way he played off another trick on the butler. Strolling one summer's evening about his grounds, he came across a beggar who was taking his road up to the house. The Squire at once proposed that they should exchange clothes, or, at least, their outer garments, and the other being naturally nothing loath, the metamorphosis was quickly completed. Bidding the man stay where he was, and with a tattered hat hanging over his eyes, and otherwise capitally got-up, he returned to the Hall, where but a few minutes previously he had been seen sitting at the dinner-table. Here he begged in vain of his own servants; they only jeered at him; but, at length, on his asking for something to drink, they offered him the dregs of a barrel, which he indignantly refused. "You fare too well," said he, "and get saucy in your places, or you, who can have so much good wholesome beer whenever you choose, would never give a fellow-creature such 
stuff as this." Some of the household now began to fight a little shy, but the butler, hearing the noise, came out at once and ordered the sturdy mendicant off the place, threatening to, if he did not actually, send for the constables. But, in the interim, imprudently venturing to put his hand on the beggar's shoulder, Mytton sent him reeling, as he did one or two more of the men who came to their superior's assistance. They then let the dogs loose, when he at once rushed off to the bear, who more readily recognised her master, and, released from her chains, raised herself on her haunches in his defence. This let out the secret, as none but Mytton would have dared to have done so much with Nell, as she was called; and often afterwards, greatly to the butler's and the other servants' annoyance, would the small-beer story be told against them. Then, again, during harvest-time, Mytton went, in the garb of a countryman, to Jones at the Queen's Head, at Oswestry, and asked for work. The terms being agreed to at so much a week for the job, the master stood a pot of strong beer to bind the bargain, and then the new hand quickly called for another, which he seasoned with brandy. It, of course, ended in his getting very riotous, and, when just about to thrash the landlord, 



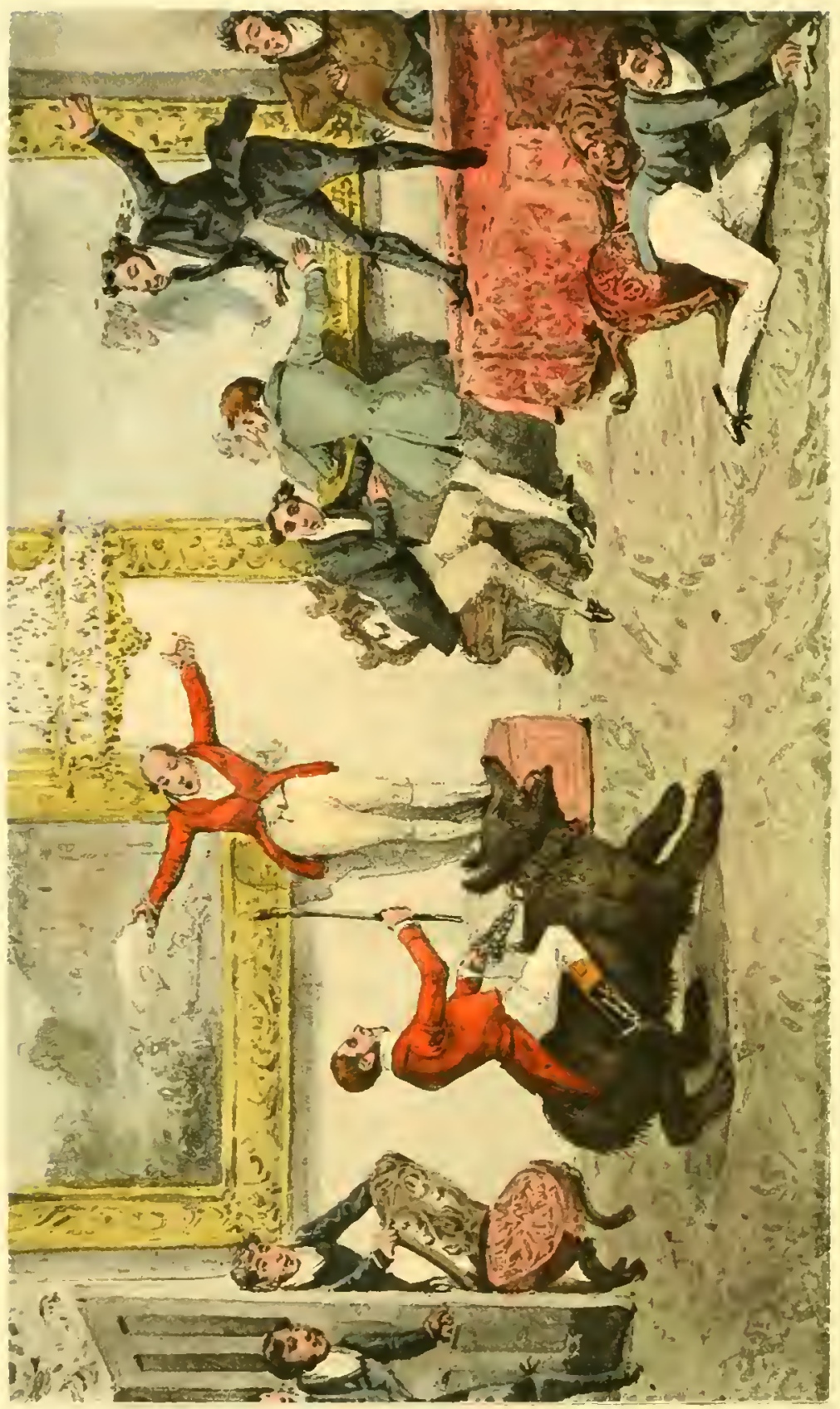




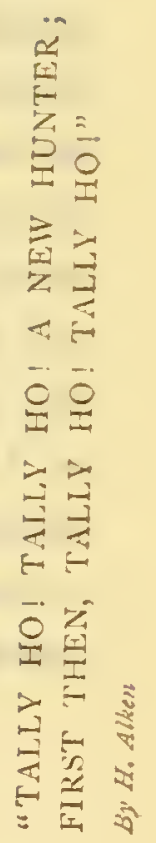




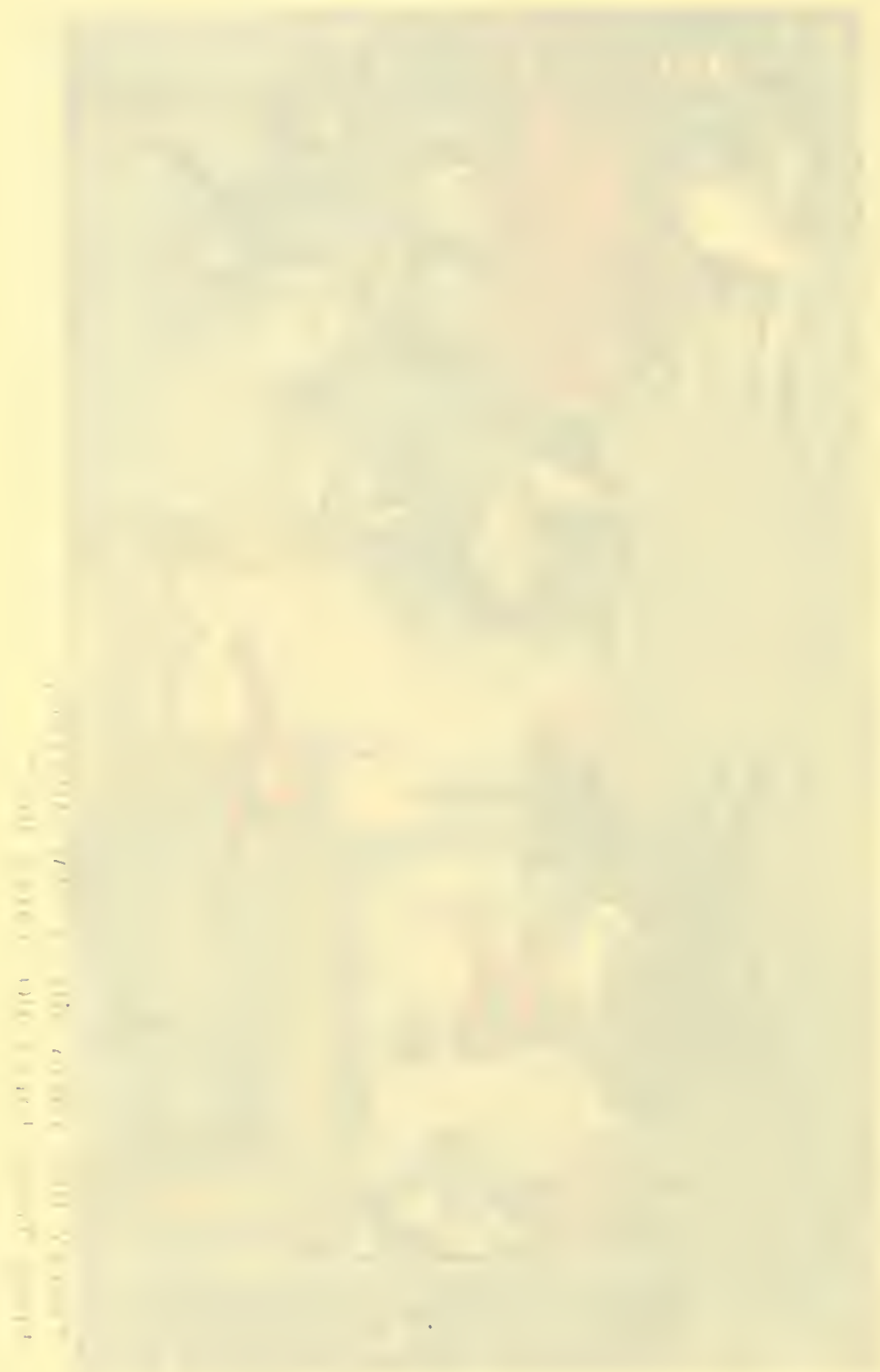


who was going to turn him out, a customer recognised the Squire, and the joke happily resulted in no serious consequences to those upon whom it was tried. On another occasion he was told that the late George Underhill, the celebrated Shropshire horsedealer, was in his house, on his road from Chester fair. Sending for him into his dining-room, he made him excessively drunk, and put him to bed with two bull-dogs and the bear! He once rode this bear into his drawing-room in full hunting costume. The animal carried him very quietly for a certain time; but, on being pricked by the spur, she bit her rider through the calf of his leg, inflicting a severe wound. The mention of this bear reminds me of another amusing anecdote. Having sent one of his stableboys with a hack to meet a friend who was coming by a coach, the latter exclaimed, on riding into the Halston stable-yard, "Ah! bruin!"--alluding to the bear. "Oh yes, sir," observed the lad, "we always brews twice a-week at Halston." What I am now going to relate I know not how to define, for in most people's opinion it rather exceeds a joke. As we were eating some supper one night in the coffee-room of the hotel at Chester, during the race week, a gentleman, who was a stranger to us all, was standing 
with his back to the frie, talking very loudly, having drunk too much wine. "l'll stop him," said Mytton; and getting behind him unperceived, put a red-hot coal into his pocket!

But I liave a better, inasmuch as it was a more harmless, joke, to relate with respect to George Underhill, the dealer. He rode over one day to Halston, to dun Mr. Mytton for his demand upon him, which, I believe, was rather a largre one. After having been made comfortable in the steward's room, Mytton addressed him thus:- "Well, George, here (handing him a letter) is an order for all your money. Call on this gentleman, as you pass through Shrewsbury, and he will give it to you in full." Now this gentleman-also a banker-was one of the governors of the Lunatic Asylum, and the order for payment ran thus :-

IIALSTON.

SiR,

Admit the bearer, George Underhill, into the Lunatic Asylum.

Your obedient servant,

John Mytton.

The mention of the trick he paid the Jew money- 
lender bears a resemblance to one he paid a tollkeeper near his own house, who had demanded and received double toll from him on the score of its being past twelve o'clock at night, whereas it was only just eleven, and the toll had been once before paid during the day. Although it was a bitter cold night, Mytton waited till the gate-keeper was warm in his bed, and then repassed the gate, of course without paying again. Nor did the frolic end here. No sooner was the fellow once more in bed, than the word "Gate!" again resounded in his ears; and finding out whom he had to deal with, he gladly returned the money, and enjoyed the rest of the night in repose.

The history of this bear may not be unworthy of notice. Mytton purchased her (it was a female) when very young, together with a monkey, from a strolling showman who was passing through Ellesmere, a town five miles distant from Halston, for the sum of thirty-five pounds for the two. Having been upwards of seven years in his possession, and handled at an early age, the former was tolerably tractable for an animal so naturally savage; but she was not to be trifled with by strangers. It was indeed in consequence of her injuring one 
of the servants of the establishment that Mytton ordered her to be put to deatl, which, as fire-arms were not resorted to, was said to have been a very difficult undertaking. In self-defence she severely wounded one of her assailants.

The death of the monkey was quite in character with his life-bordering strongly on the ludicrous. Like his master, Jacko was fond of his bottle, and mistaking a jar of Day and Martin's blacking for something of a more vinous quality, he drank so freely of it as to produce an illness which deprived him of his eye-sight, and eventually caused his death. Many of his exploits have been related to me, such as his performance, after hounds, on the horse called "The Devil," but as I have no personal knowledge of them, I am unwilling to give them publicity. They bear too close a resemblance to some old Joe-Miller stories of the same amusing animal; as do some similar tales of other "mounts" on "The Devil."

It was said of Napoleon, that he wished to banish the word "impossible" from the French Dictionary. Mytton must have had some such desire; for he once told me, at Halston, that he had a filly in his racing stable which should win 



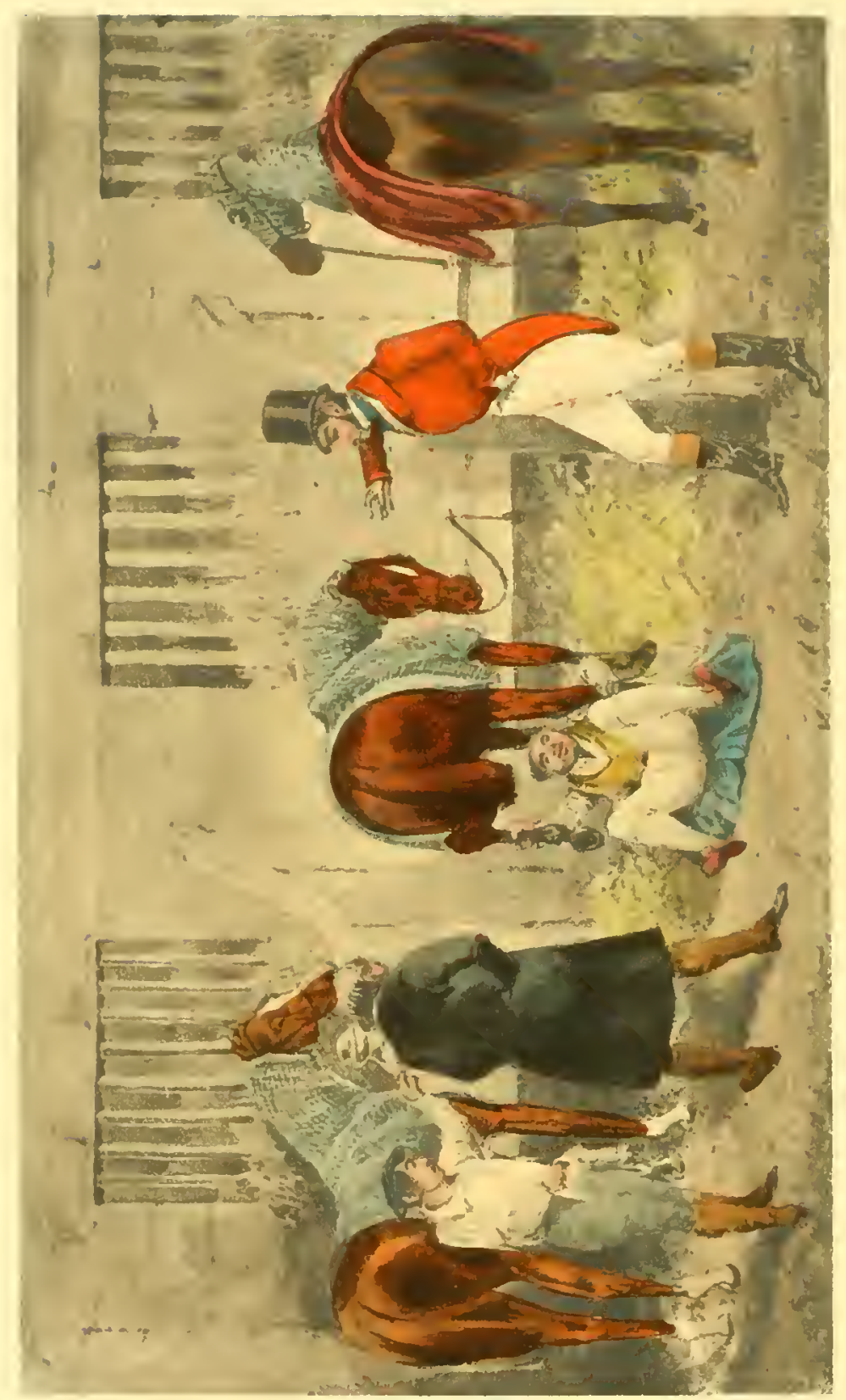




$$
\text { 资 }
$$



the Oaks (she was named in those stakes), and afterwards she herself should put them into his pocket. On my ridiculing the idea, he said,-." Why not? She will now put both her hind feet into my pockets, and why not her mouth?" I accompanied him to the stable, and to my horror witnessed the latter exhibition. Mytton laid himself down at full length under her belly, with his bare head between her heels, and first taking up one foot, and then the other, placed them both in the pockets of his dressing-gown. William Dilly, his trainer, witnessed all this as well as myself; but on his attempting to take liberties with a horse called Oswestry, in the next box, who was of a very different temper, his worthy servant thus addressed him: "You will do that once too often, sir, with this horse; and, good-tempered as she is, should your Oaks filly become alarmed, she will surely knock out your brains." "Good advice, Mr. Dilly," said I, as I turned away from the awful scene, "but you may spare your breath; John Mytton will be John Mytton; he heareth not the voice of the charmer. charm he never so wisely, and, like Homer's divinities, is always in mischief."

But I must not do as Homer did by his heroes, 
make mine a savage. And yet how are we to define some of the darings and doings of this extraordinary man! For example, the following description of an evening at Halston was given by me in the "Sporting Magazine" some years back. After describing a display of young foxes which were brought into the dinner-room for inspection, I thus proceed:- "We were now offered the company of the bear, but to a man declined the honour. By way of a finish, however, we had one turn-up between a Spanish bull-dog and an animal called Blood -a cross between a Spanish bull-dog and an English mastiff; when our host, thinking that Blood 'was getting bloody', and might kill the other dog, ran at him and pinned him by the nose; and, although weighing more than seventy pounds, he raised him from the ground with his teeth, holding him suspended for at least a minute, without the smallest assistance from his hands." Neither is this a solitary instance of his contest with ferccious dogs. Returning from hunting one day, he, with some others, called to lunch at a farm-house called the Berries, near Whitchurch, where there was a very large and savage dog chained in the yard. "Pray don't go near him, Mr. Mytton," said his owner, 



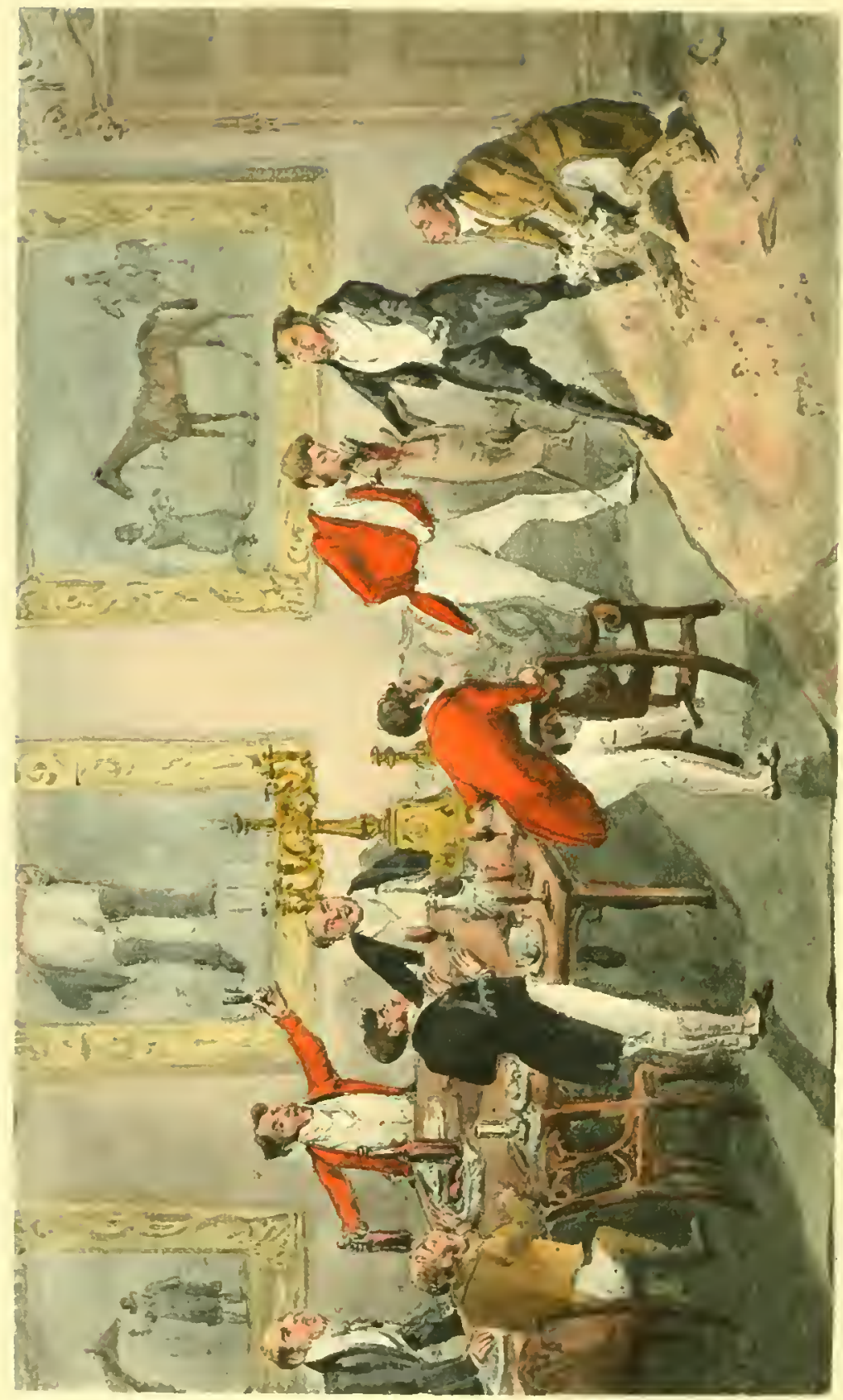




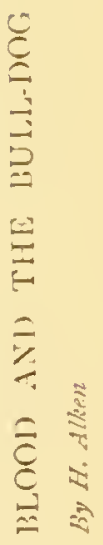


$=$
$=$
$z$
$=$
$=$ 
"for he will tear you in pieces if you do." This was enough for Mytton; so pulling a silk handkerchief out of the pocket of a friend, and lapping it around his left hand, he advanced with it extended towards the dog, who immediately seized it with his mouth. Reader-I fancy I see you shudder! but don't be alarmed; and when you hear the sequel, perhaps you will think that the dog might have been the greater sufferer of the two, provided blood had been drawn. Catching him by the back of the neck, however, with his right hand, Mytton instantly pinned the animal by the nose with his teeth; * and getting the other hand at liberty, so pummelled his opponent that he had scarcely any life left in him. As might be expected, the dog never afterwards liked the look of his brother bull-dog or even a red coat, but slunk into his kennel on the approach of either one or the other.

The terms good-natured and good-tempered are very often confounded by being indiscriminately applied to the same person or animal, whereas they

* The first mention of Mr. Mytton's name in any of Nimrod's writings is when, after Chester race week, he went back to Halston with his friend, that "hard-riding, hard-dining, hard-going, hard-striking, hardbiting, thorough-bred Briton;" the hard-biting epithet having its application in this anecdote. 
almit of no inconsiderable distinction; and we have a striking instance here. Mytton, by nature, was kind and beneficent to a degree very rarely witnessed. I will not go so far as to say-what Crabbe's son says of him-that "no sympathy was like his," yet, with a pretended insensibility to the common sympathies of our nature, he never saw misery that he did not wish to relieve it. The conflicting elements of his character, or, more properly speaking, some parts of his concluct, may appear to give the lic to this; yet all who knew the man know that I have spoken the truth, and the tears of the multitude that were shed at his grave place it beyond dispute. In his temper he was sudden and violent, and, like Achilles, impatient of restraint; yet his wrath endured but the twinkling of an eye, and in forgiveness of injuries he had no equal within my knowledge of mankind. What a paradox then is here! With all his native goodness of heart, he appeared to wish to make the world believe he cared no more than Dionysius for the gods what the world thought or said of him; and although his good sense must have convinced him that there is a profligacy of spirit in defying the rules of decorum, he oftentimes acted as if he considered every law, human or divine, of little 



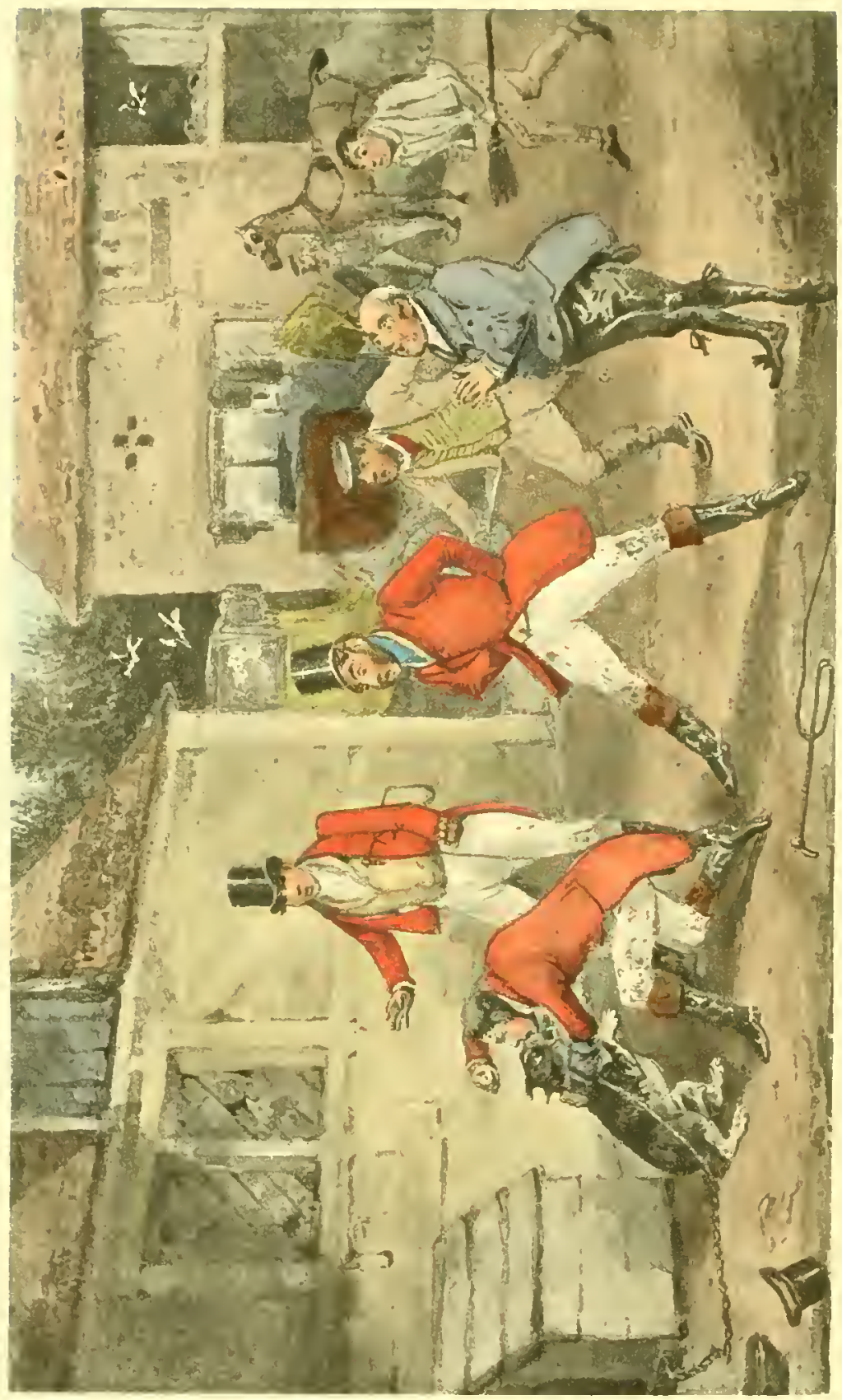




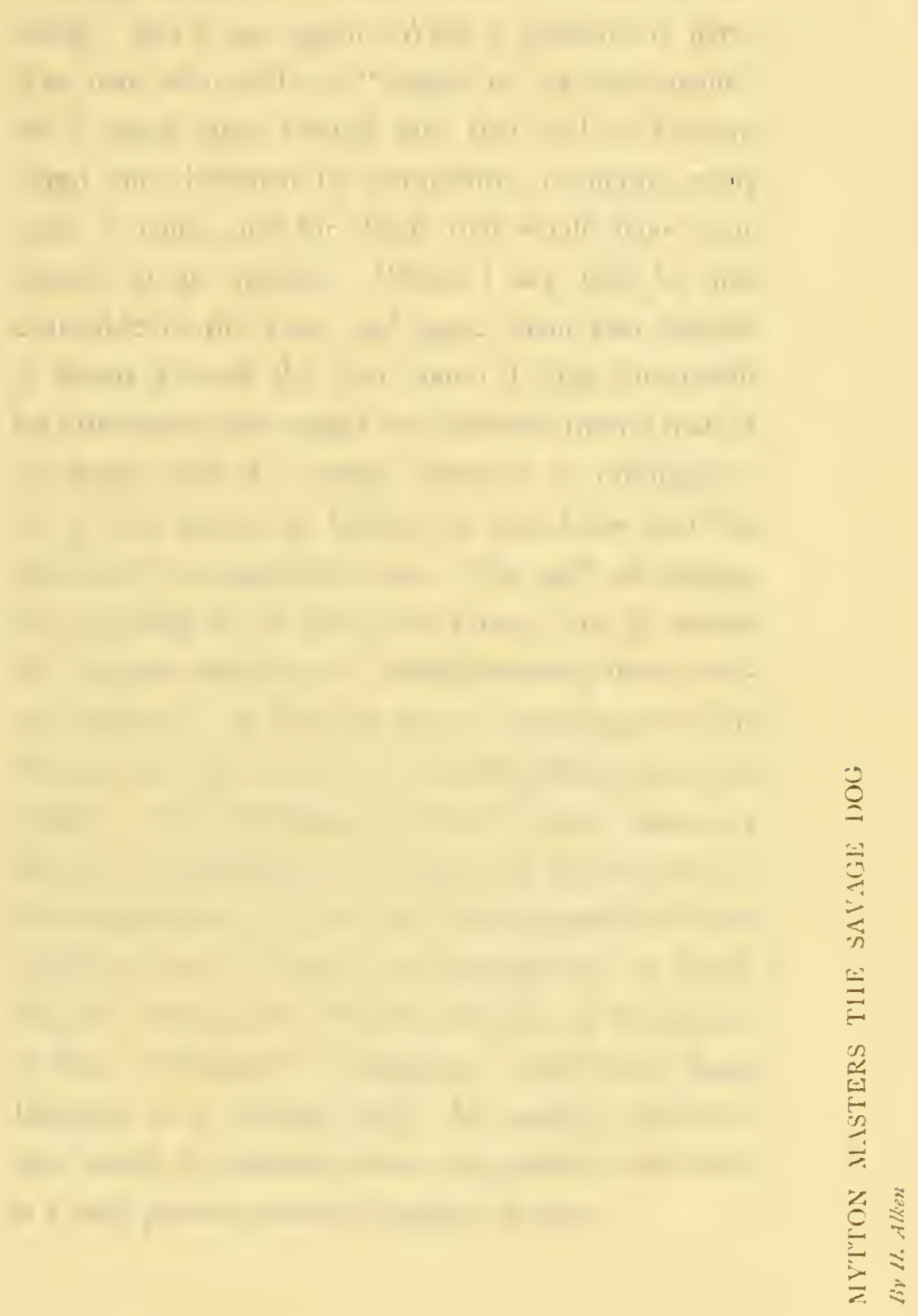


$\vdots$
$\vdots$
$\vdots$
$\vdots$
$\vdots$
$=$
$\vdots$
$=$
$\vdots$
$=$
$=$
$=$ 
worth. But I say again-What a paradox is here! The man who had no "regard to his good name" left a good name behind him that will be remembered and cherished in Shropshire for many, many years to come, and for deeds that would have done honour to an apostle. When I say that he was charitable to the poor, and gave them two bushels of wheat a week the year round, I give him credit for little more than might be expected from a man of his means, and of a nature generous to prodigality; but I have reason to believe no one knew half the extent of his beneficent acts. 'Tis said of charity, that it admits of no error but excess; and to excess did he often carry it, as I shall presently have occasion to show. In fact, he was as extravagant in his virtues as in his vices,-or, I would rather say, in his failings. The perfection of man's moral nature is said to be forgiveness of injuries, but Mytton went a point beyond this. Even that hard injunction of the Gospel, to love an enemy-the characteristic of a religion not of man, but of God, and that, as the author of the "Adventurer" observes, "could have been delivered as a precept only," for society could not exist under its practice-was no paradox with him. as I shall produce several instances to prove. 
But to return to his nature. Pythagoras, being asked in what man could resemble the Divinity, replied, "In beneficence and truth." Here, again, we have a paradox. The man who sometimes assumed the character of a fiend, and appeared to strive against the native goodness of his heart, answers to that of the Deity; for inasmuch as his beneficence was unquestionable, so was his veracity unimpeachable. Setting aside jesting, in which none dealt more largely-in fact, he was a sort of human Silenus-no man could with more safety be spoken after than Mytton could. I am quite certain nothing could have induced him to have uttered a premeditated untruth, for any unworthy purpose; and there was a good-humoured and affectionate simplicity about him that rendered him a great favourite in his neighbourhood. Again, he was no backbiter. On the contrary, when he heard the "voice of slander rankle on the ear," he always turned the discourse, saying as my uncle Toby did, when his Corporal was reckoning up all the rascals of his regiment, "VVe will speak of this another time." In his dealings with the world he was a man of strict honour and probity; and without justifying his extravagance, I may be allowed to say that his 
chicf concern, after the last estates he could sell were disposed of, was not whether he himself might be left destitute, but whether there would be enough to pay his creditors in full. As a master he was kindest of the kind, and a liberal and most considerate landlord. Surely, then, this man must have been either counterfeiting a nature not his own, * or he must have been, to a certain extent and on certain points, a madman! No doubt he did the one; and no doubt he was the other!

The worst feature in poor Mytton's disposition, and what may be termed the reigning error of his. life, was, not only that he would not bow to reproof, much less kiss the rod, but he would suffer no man either to counsel or advise him. There was, however, none of "obsequinm amicos, veritas odium, parit," that Terence speaks of, about him, for he always received it in good part, being neither flattered nor offended; but he would not take ad-

* The following was related to me by the medical gentleman at Oswestry who attended the accouchement of the first Mrs. Mytton: - "Mr Mytton," said he, "was in the billiard room when I went to inform him of the birth. 'What is it?' he inquired. On my telling him it was a girl, he swore he would have it smothered; but, throwing himself on a sofa, gave vent to his feelings in a flood of tears, and his anxiety for the well-doing of his wife would have done honour to any man." 
vice even when given him by his sincerest friends, and with the purest and most disinterested motives. He always considered it an impeachment of his understanding, generally exclaiming to those who offered it, "What the $d-1$ is the use of my having a head on my own shoulders, if I am obliged to make use of yours ?" But, unfortunately, at times his ears were deaf to the voice of reason, as the following anecdote will show:-Previously to the disposal of the first property that he sold, I happened to be at Halston, and was about to accompany hin to Lichfield races, where each had horses to run. Just before we set out, his agent, the late Mr. Longueville, of Oswestry, arrived at the house, and wished to speak to me. As nearly as I can recollect, the following were his exact words: "I have reason to believe you can say as much to Mr. Mytton as any man can; will you have the goodness to tell him you heard me say, that if he will be content to live on $6000 /$. per annum for the next six years, he need not sell the fine old Shrewsbury estate that has bcen so many years in his family, and at the end of that period he shall not owe a guinea to any man?" I fancy I see the form and features of my old friend, with the manner in which he received and replied to the flattering pro- 
position, and many others who knew him as well as I did will also have the picture in their mind's eye. Lolling back in his carriage, which was going at its usual pacc, and picking a hole in his chin, as he was always wont to do when anything particularly occupied his thoughts, he uttered not a syllable for the space of some minutes; when, suddenly changing his position, as if rousing from a deep reverie, he exclaimed with vehemence, "You may tell Longueville to keep his advice to himself, for I would not give a $d-n$ to live on six thousand a year." Knowing his regard and esteem for that worthy gentleman, it was in vain to urge the subject any further, for there was that in his manner which convinced me he was not to be perstiaded on this point by any man,-no, not though one rose from the dead. Hence is his ruin dated.

From the serious to the jocular is but a step, and the mention of this circumstance leads to a joke. A near relation was endeavouring to dissuade him from parting with a certain estate, on the score of its having been so long in the family. "How long?" inquired Mytton. "Above five hundred years," was the reply. "The $\mathrm{d}-\mathrm{l}$ it has!" he returned, "then it is high time it should go out of it." 
With a perfect contempt for the splendour of cold-hearted opulence, Mr. Mytton lived very much like a gentleman at Halston, where everything was in keeping with his fortune and station in life. There was no unnecessary display-two men-servants out of livery, and two in livery, being the full complement at the dinner-table, nor did he inclulge in the luxury of a man-cook. Although himself a perfect stranger to the science of economy, his establishment was managed with considerable regularity; and notwithstanding the consumption of good things in the servants' hall, for the number of stable servants was great, it was not Halston that ruined him. It was that "largeness of heart, even as the sand that is on the sea shore," which Solomon possessed, but unaccompanied by his means as well as by his wisdom, which ruined Mr. Mytton; added to a lofty pride which disdained the littleness of prudence, and a sort of destroying spirit that appeared to run a-muck at Fortune. By a rough computation, and a knowledge of the property he sold, I should set down the sum total expended at very little less than half a million sterling within the last fifteen years of his life!!

But how would this expenditure be accounted for 
if something like a schedule of his disbursements were to be called for? The task would be an Herculean one, but Horace would furnish a commentary upon it. Some persons hunt, says he; some race, some drink, some do one thing and some another; but Mytton, in sporting language, was "at all in the ring." $H$ is fox-hounds were kept by himself without any subscription, and upon a very extensive scale, with the additional expenses attending hunting two counties. His racing establishment was on a still larger scale, having often had from fifteen to twenty horses in training at the same time, and seldom less than eight. His average number, incleed, of thoroughbred stock at home and from home, including brood-mares and young things, was about thirty-six! is His game preserves were likewise a most severe tax upon his income. Will it be credited that he paid one bill of $1500 l$. to a London game-dealer for pheasants and foxes alone! The formation of three miles of plantation which this game went, in part, to stock, must

- Mytton thus wrote of himself in the year 1825:- "I own Longwaist, and some fifty other thoroughbred ones; a few hunters, a few hounds, course a little, and sonetimes fight a main of cocks." Longwaist was a purchase ftom Mr. Fulwar Craven, almost as great "a character" as John Mytton himself. 
have cost him an immense sum; having had, for several years, as many as fifty able-bodicd labourers in his employ; while the keepers on the neighbouring properties were commissioned to save all the vermin they could for him, and week by week men poured into Halston with sacks of badgers, stoats, and polecats.

There is this line somewhere, though I cannot recollect where-

"Dress drains our cellars dry ;"

but such was not the case at Halston, and I believe the satire applies to the ladies. It was hard to say, however, which was the better stocked of the two, Mr. Mytton's wardrobe or the Halston cellars. I once counted a hundred and fifty-two pairs of breeches and trousers, with a proportionate accompaniment of coats and waistcoats, in the former; and I think I, on another occasion, described the "hogsheads of ale, standing like soldiers in close column, and wine enough in wood and bottle for a Roman Emperor," in the latter. He made his own malt, and John Mrtton, Licensed Maltster, was painted in large letters over the malt-house door. The clothes he would put on his person just as they 
came to his hand, or as his wild fancy prompted him; and I have seen him nearly destroy a new coat at once wearing. His shoes and boots, all London make, and very light, were also destroyed in an equally summary manner, in his long walks over the country, through or over everything that came in his way. It is impossible even to guess at his annual expense in post-horses; but every post-boy in England lamented the fall of "Squire Mytton," their very best customer. But he was rather hard on them at times. Returning once from Warwick races aftcr sleeping at Birmingham, the pace, though strong, was still not good enough; and, after com. plaining in vain, Mytton abruptly ordered the postboys to stop. On their doing so he pulled one lad off his horse, and his friend the other, and, packing thcin into the chaise, the two travellers mounted in their stead, and so finished the stage. The appearance of the horses and the boys-for they had both been badly used-told its tale, and the golden remedy had, as usual, to be applied. On another occasion, with the same companion, being late in getting to the fixture with hounds, he ordered the post-boys to take a short cut down a lane at Steele, near the Twemlows. There having, however, been just previously 
a very heavy rain, this road was rendered impassable, but Mytton would go on, until the chase at length fairly stuck fast. There being no other conveyance handy, the Squire jumped on one of the posters and his friend on another, and with the traces hanging about their heels, galloped up to the cover-side! If he was a friend to post-boys, he was equally so to others who served him, and often as he passed through Birmingham, he never gave the waiter where he stayed less than a guinea. I have reason to believe that the money he has at various times lost (not at play, for there I should say he was borne harmless *) would have purchased a pretty estate. I am afraid to say what was supposed to have been the amount of bank-notes that were one night blown out of his carriage on his road from Doncaster races, but I have reason to believe it was several thousand pounds! His account of the affair was this: He had been counting a large quantity of bank-notes on the seat of his carriage-in which he was alone-with all the windows down; and falling asleep, did not awake until the night was far spent-his servant paying the

- He was a very dangerous man with a dice-box in his hand. Wine gave him courage, which generally tells at hazard. 



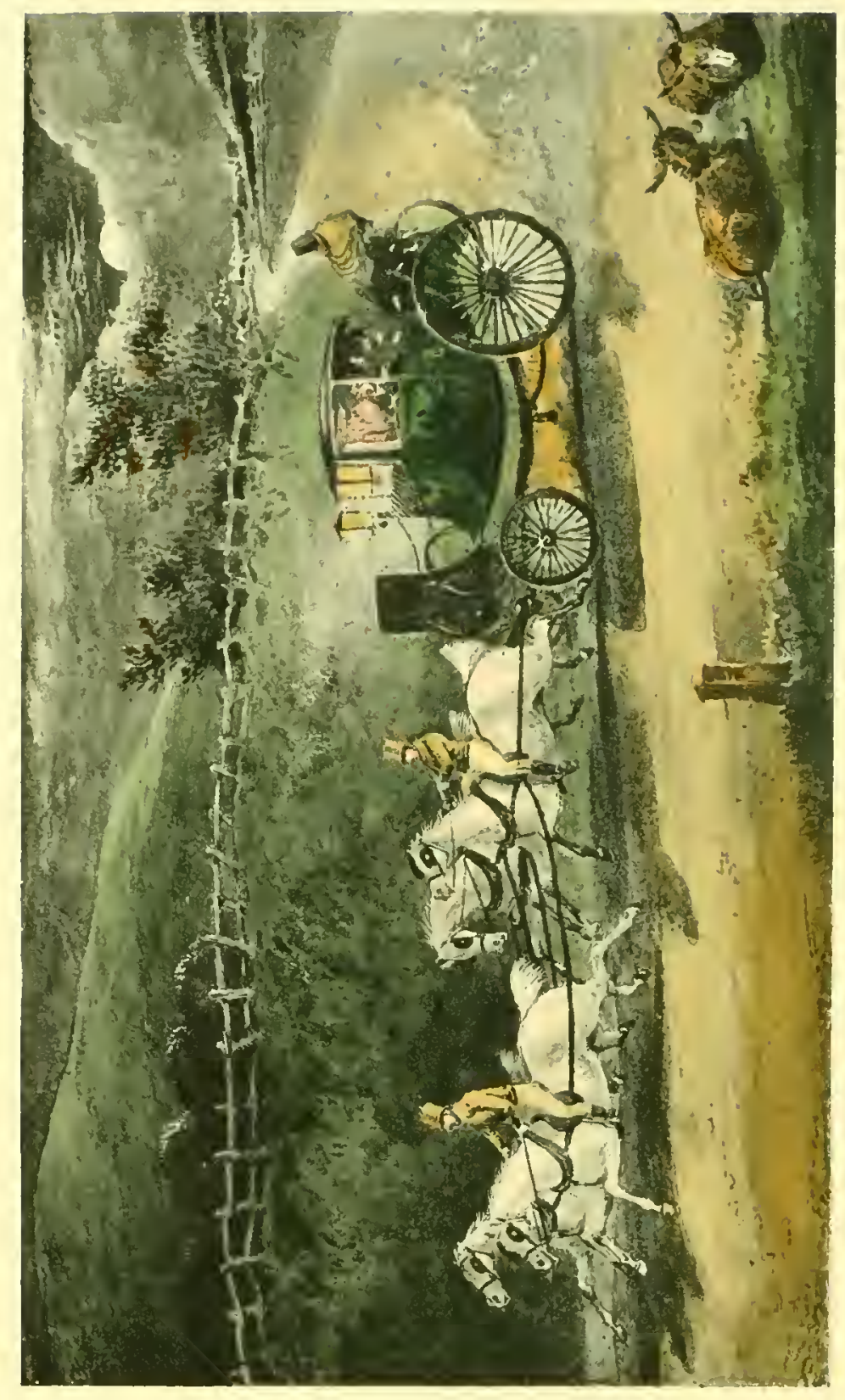




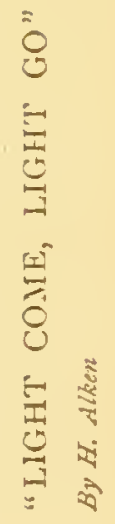




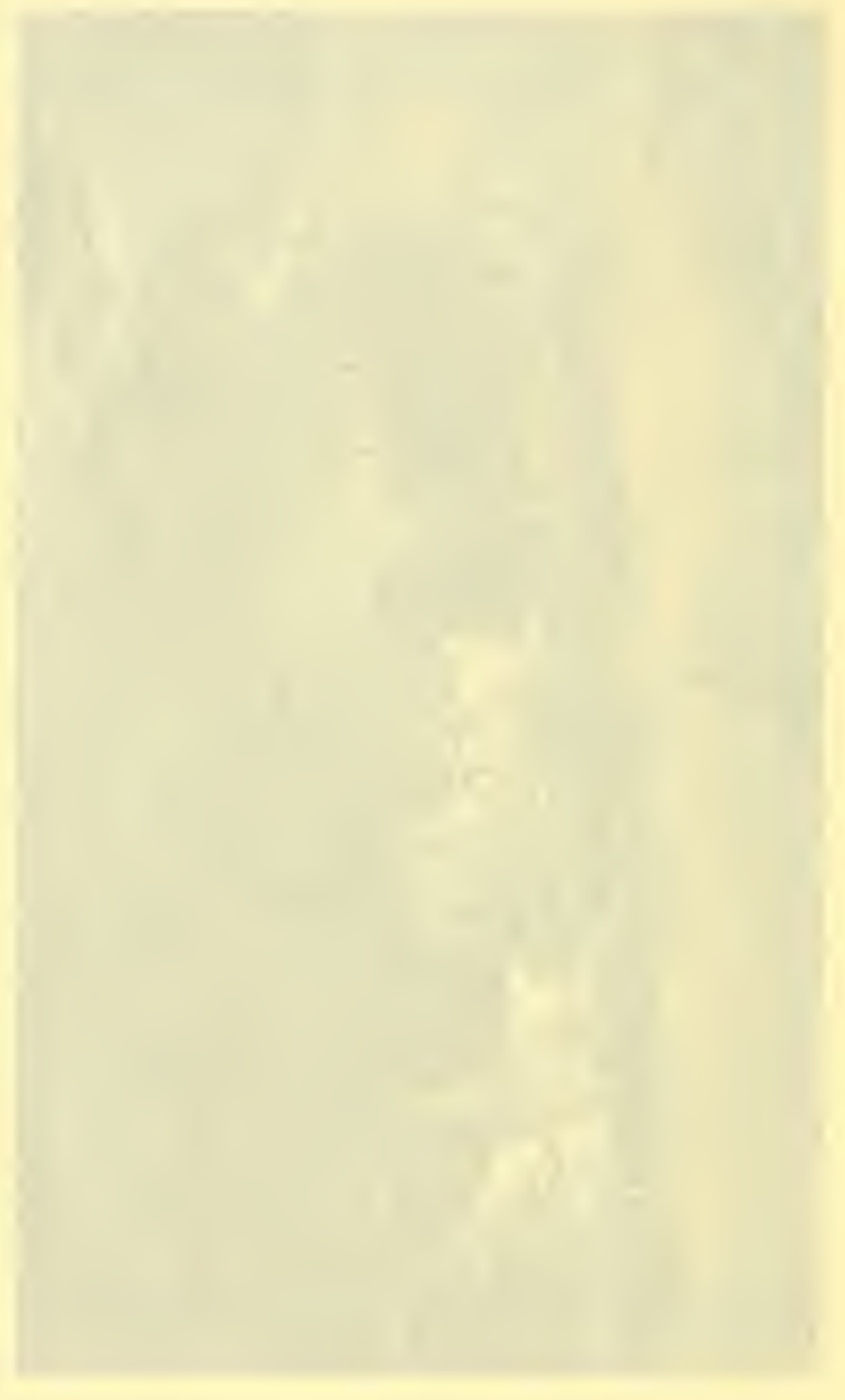


charges on the road. An equinoctial gale having sprung up, carried great part of the notes away on its wings, verifying the proverb of "light come, light go." It was always his custom to have a large sum of money in his travelling writing-desk, but it was more than usually large at this time, in consequence of his having broken the banks of two well-known London Hells on the eve of his departure from London for Doncaster. Like Democritus, however, Mytton laughed at everything, and always spoke of this as a very good joke. I have seen him, when he has been going a journey, take a lot of bank-notes out of his desk, and, rolling them into a lump, throw them at his servant's head, as if they had been waste paper; but his chaplain used to say, he always knew what the lump contained, and how far it would carry him-a fact by no means so clear to me. I picked up one of these lumps some years since in the plantations at Halston, containing 37 ., which had been there some days by its appearance; and as he never had pockets in his breeches, such occurrences must have been frequent.

Perhaps there was one cause of expense incurred by John Mytton that is not to be traced to any other man; but, as Charles the Fifth profanely boasted 
that "there was only one God and one Charles," surely there never was but one John Mytton. This said John Mytton would never open letters secured by wafers, unless he were acquainted with the handwriting. Thus were tradesmen's applications unanswered till their patience became exhausted, and law proceedings were, in consequence, resorted to. But he cared no more for writs than he did for anything else, as they, of course, were sent to his solicitor, and all he knew of them, in his prosperity, was, that he paid for them. So popular, however, was he with the lower orders, that, in his prosperous days, I do not think a bailiff in the four surrounding counties would have arrested him, had he been instructed so to do.

It is impossible to separate the sort of vis comica that attached itself to the various acts of imprudence of my, otherwise, truly noble-minded friend; and perhaps the anecdote of the London game-dealer, and his I 500l. bill, is about as amusing as any. On his arrival at Halston he presented it himself to his debtor; but it appeared from his subsequent conduct that he little thought it would have been paid without somathing like a scrutiny into its morits. Here, how. ever, was John Mytton "sui generis" again. "Give 
me a pen and ink," said he, casting his eye over the amount: and, scratching the words, "Right, John Mytton," with his usual expedition, under it, exclaimed, "There, take it to my agent, and get the money." As may be supposed, the joy of this man was excessive, but its outbreak was reserved until he saw the agent at Oswestry draw a cheque at sight for the entire sum. It was then no longer to be restrained, and thus did the dealer in dogs, foxes, pheasants, and monkeys, et hoc genus omme, give vent. to the noble feelings of his nature. "Oh, my dear sir," said he, "what can I do for you, in return for all this kindness?" "I have done you no kindness," said the agent; "the only favour you can confer upon me is, never to let me see or hear of you again." This, however, did not satisfy the pheasant-merchant, who was anxious, if not to make a display of his gratitude, at all events to propitiate the good-will of the agent, and once more addressed him, "Pray, sir," said he, "are you a married gentleman ?" On being answered in the affirmative, the nature of the donation was determined upon. "Then, sir," added he, "allow me to present your lady wi.h a monkey!" Well might the man of law have exclaimed- 
but when he was made acquainted with the nature of the gift, the would-be giver was very soon despatched, and I never heard whether he again made his appearance, on a similar errand, at Halston.

The next anecdote that presents itself to my mind arose out of my seeing him get out of his carriage at a cover's side, and walk towards his hunter, to mount him. "There he goes," said Tom Penn; "he's a lily, ain't he? Give him two hundred thousand a year, and I'll bet a hundred he's in debt in foive (five) years." But it is necessary to say who this Tom Penn is, or rather was, for he is also in his grave, having broken his neck in hunting. He was pad-groom to Sir Watkin Williams Wynn, Bart., much looked up to, and consequently often consulted, for his correct judgment of a hunter, by the help of which, although an excellent servant, he was one of the most impudent fellows that ever wore a livery; or, perhaps, more properly speaking, what is known in the lower world as "a regular cool hand."

Now a question arises, not unworthy of discussion, Did the late Mr. Mytton really enjoy life amidst all this profusion of expenditure; and was he, in the best of his days, in a situation that many poor men would covet? This, I think, admits of a doubt. It is true, 
he had most of the requisites for a man of a noble fortune that Horace granted to his friend Tibullus; but one thing was wanting-the "artemque fruendi," the art of enjoying it, to which he, Mytton, was a stranger. Indeed, to a vitiated palate, always calling for fresh gratifications, the wealth of Crosus might fail in procuring that one thing wanting; but there was something about my friend that gave one the idea that to hin it was peculiarly denied. There was that about him which resembled the restlessness of the hyena; and whether in the pursuit of his pastimes, or the gratification of his passions, there was an unsteadiness throughout, which evidently showed that, beyond the excitement of the passing moment, nothing afforded him sterling pleasure. All those who watched his actions might perceive, that his object was to have a taste of everything that was alluring and delicious; and, like the bee, to rove from flower to flower, merely culling a little of the sweets of each. Look, for example, at the various sources of amusement Halston afforded, and the small share of calm enjoyment they appeared to afford the owner of them. What elegant dinners have I seen him sit down to at his own table, with no more appetite to partake of them than an alderman has when singing 
"Non nobis, domine," having an hour or two before been eating fat bacon and drinking strong ale at some tenant's or other farm-house on his road home from his field pursuits. Again: if he had a good racehorse in his stables, he would run him off his legs, nearly to his destruction; and he served his favourite hunters in the same manner. All this could have been reconciled with youthful enthusiasm and Welsh blood; but with Mytton it could be only traced to one cause, which grew with his growth, but did not quit him in his manhood, and finally plunged him into the abyss of misery!

But if the proprietor of it himself was not satisfied with the resources which Halston afforded, few of his friends were so unreasonable as to liave looked for amusement and not found it; for, indeed, the very proprietor of it alone, with his various appendants and his frolics, was a constant source of mirth. A celebrated historian of the Augustan age, however, now presents himself to my view, and wisely reminds me, that decency is a principal virtue in an historian, and that he should preserve the characters of the persons, as well as the dignity of the actions of those of whom he treats. Heretofore I trust I have written nothing that can be construed into more than an 
allowable levity of style, inseparable from the chronicling of the sayings and doings of such a character as is before me; and as one object is to display it in every variety of colour-and the rainbow itself has not more-I must here introduce a description of an evening at Halston from my own pen, as published originally in the "Sporting Magazine." As it commences with an apology, I shall offer none here.

" What Cato did, and Addison approved, cannot be wrong,' said a learned and accomplished gentleman of the last century, when he put a period to a miserable existence. Now, as the great essayist here named introduced his friend Sir Roger's chaplain to the world, perhaps I may be allowed to introduce Mr. Mytton's. He is a very old acquaintance of mine, and I know he will pardon me for doing so. I cannot exactly say he is to his patron what Mæcenas was to Augustus, or what Falstaff was to Henry; but rather what Crispus was to the Roman Emperor. Crispus lived with four of them, joked with all of them, and quarrelled with none of them, though their ears were perhaps more tender than their hearts. The Halston Chaplain, however, is entitled to a place in the 'Sporting Magazine,' having given birth to as much sport as ever was seen in a race, a cock-pit, or 
a fox-chase. In a style peculiarly his own, he says more good things than any other man I ever met with, and by his good-humour, and inoffensive jokes, has often made the old Halston welkin ring.

"The connection between them commenced thus: Soon after the Chaplain left the University, he resided in the neighbourhood of Halston, and was fixed upon as a sort of friendly preceptor to the heirapparent to the estate, both before and after he left IVestminster School; and here, perhaps, one of the best anecdotes has its source. It appears there was some difficulty in persuading the young Squire to go to College; and when we consider a little, our wonder ceases. October is the best month for pheasantshooting; Christmas lasts till Easter at Halston; and hunting, fishing, and shooting last all the year round. The Chaplain, however, was employed to use all his eloquence to induce him to go, and the following dialogue passed between them :

"Chaplain. My good sir, you must go to $\mathrm{Ox}-$ ford; you must indeed, sir!

"M/. Mytton. I'll see you — first.

"Chaphain. Upon my word, sir, you must go. Every man of fortune ought to go to Christ Churcho if only for a term or so. 
"Mr. Mytton. Well, then, if I do go, I will go on the following terms.

"Chaplain. What are they, sir?

"Mr. Mytton. Why, that I never open a book.

"Chaplain. Not the least occasion-not the smallest, I assure you.

"Mr. Mytton. Very well then, I don't mind going. provided I read nothing but the 'Racing Calendar' and the 'Stud Book.'

"Chaplain. Excellent books, sir ; they will do very well indeed.

"The next amusing anecdote of the Chaplain arose out of the following circumstance:-Going one morning, as usual, to serve the family church at Halston, Mr. Mytton contrived to take his sermon out of his pocket, and substitute in its place the last number of the 'Sporting Magazine.' When the Chaplain had mounted the rostrum, and was preparing to throw off, he found his mistake, and, of course, had nothing to do but to apologise to his hearers for the loss of his sermon, and, "with a wellbred whisper, close the scene.' It is also said of him, that having a tender regard for his patron, and knowing the natural kindness of his disposition, he has always avoided wantonly hurting his feelings; so 
that, on some occasions, when it has been his intention to preach a sermon, which, to use his own words, he feared might 'hit him hard,' he has been prepared with another, ' in case the Squire should be in church.'

"There is another story of the Chaplain, which, though it has been before recorded, yet it was not placed to his credit, but to him alone it is due. About five years back, he applied to his Diocesan to give him a living, and the Bishop promised him the first that was vacant. Having a pretty private fortune of his own, and not aspiring to a mitre, the Chaplain took the liberty of requesting that his Lordship would not send him into the Welsh mountairs, but give him an English living. The Bishop, knowing him to be a thoroughbred Welshman (and, indeed, no one would take him for a half-bred one), demanded of him his reasons for such a request. 'Why, my Lord,' said the Chaplain, 'my wife does not speak Welsh.''Your wife, sir,' said his Diocesan, 'what has your wife to do with it? She does not preach, does she?" - No, my Lord,' said the Chaplain, 'but slue lectures!" The Bishop, as may be expected, took all this in good part, and the Chaplain was soon afterwards exalted to a living in the wildest part of the Welsh mountains.

"No man was ever more free from guile than the 
Chaplain of Halston and Rector of - Indeed, some of his intimate friends have doubted whether he has enough of this subtle art to enable him to go through the world with eclat. Being once on a visit at an old lady's house, who prided herself on the excellence of her cook, he was requested to carve the bottom dish. On being asked to help the old lady herself, he addressed her thus: 'Pray, maram, how do you like it? Here is some very much done,- -some very little done,-and some not done at all.' On another occasion he was dining with an old gentleman in Gloucestershire, who plumed himself on the celebrity of his ale. On hearing that the Chaplain was a Welshman, and reckoned a good judge, he ordered a fresh cask to be tapped, and pledged him in a bumper of it after his cheese. No encomium being passed on it, the old gentleman ventured to ask him how he liked his ale. 'Why, sir,' said the Chaplain, we should call it very good small beer in Wales.'

"I have before observed, that the Halston Chaplain can neither be compared to Mrecenas nor to Falstaff-being completely 'sui generis.' Some years since, however, he put me in mind of a scene between the latter and his prince. We had had rather a hard night at Halston, and our host was taking a nap, at 
full length, on the sofa. After looking at him for some time, his old preceptor broke out into the following soliloquy: 'Only think, sir, what the Squire, with his abilities, might have bcen, and only see what he is !'

"On Sunday last, as is his usual custom after the duties of the morning, the Chaplain entered upon those of the evening, and took his place behind the beef. Here, Lord Chesterfield hinself never displayed a better grace; for amid the blaze and radiance of nine gold and three silver cups-the fruits of some well-contested races-his rosy face outshone them all; and it may be said of him, without offence to any one, that he is equally orthodox in the bottle as in the wood, being a Christian at all times, and one of the best-natured persons in the universe."

From my own experience of this extraordinary character, I could fill a folio or two with his sayings and doings, which were of the most ludicrous order,rendered doubly so by the easy, epicurean temper of the man. For example:-As he was one Sunday proceeding on horseback to his church, a leaf out of his sermon-book accompanied his handkerchief, as he drew it from his pocket, and, the wind being high at the time, it was carried over the hedge into a field. 
"Mr. Owen!-Mr. Owen!" shouted an Oswestry tradesman, who was following him,--" a leaf of your sermon has flown over the hedge; I'll get it for you if you will stop." "Don't trouble yourself, sir," replied his reverence; "I'll conncct it."

Then his account, related to myself, of his lending an hundred pounds to a relation, and which he had given up for lost, until the said relation came to spend three days with him, and boasted of the flourishing state of his finances, is worthy of being recorded.

"Of course he paid you?" said I.

"Not a bit of it," replied the Chaplain; "but I'll tell you how he served me. He got rather more drunk than usual the last night, and, taking my hand into his, thus expressed himself,-- 'God bless you, Will; you are the only man in the world that coor lent me a hundred pounds." "

His cousin, the "hunting, racing, cock-fighting parson," once addressed him thus :-

"Will, I think I shall give you that living of mine; it is of no use to me."

Will thanked him for his liberality, but hearing nothing further about the matter for a long period of time, he ventured to refresh his memory, when the following answer was returned :- 
"Dear Will,-I have changed my mind about giving you the living ; I fond it just keeps my hounds."

But of course the good Chaplain had in his time to put up with some horse-play. Mytton once pushed him into the fish pool on their return from church, as he also ducked Will Staples, the whipper-in, and Tinkler his stud groom. A more serious matter, however, was when he laid the wire of a spring-gun in Mr. Owen's path on his way to morning service; the shock being so great that the victim of "the joke" was unable to meet his congregation.

The Chaplain did not long survive his friend and patron : and it is generally believed that the accumulated distresses, the fallen state, and the miserable end of the one, accelerated the death of the other. At all events, I am informed that the words "poor Mytton," were nearly the last the Halston Chaplain uttered. 


\section{P A R T I I.}

WITH what extraordinary characters of ancient and modern times would John Mytton stand a comparison? With Nero? Yes ; for Nero fiddled whilst Rome was burning, and Mytton would have laughed had he seen Halston in flames. But Nero murdered his mother, and Mytton made a noble pro. vision for his." With Timon of Athens? Yes, as a spendthrift; but the one hated, and the other was kind to all mankind. With Napoleon Bonaparte? Yes, for his historian says of him, " Extreme agitation was the basis of his existence; motion was his repose; he lived in a hurricane, and fattened on anxiety and care." But one drank coffee seven times a day, and the other drank as many bottles of port wine! With the poet Byron? Yes, inasmuch as each was at Harrow School, and each fought eight pitched battles

\footnotetext{
- He added 50ol. per annum to her jointure.
} 
during the time he remained there. With Savage immortalised by his biographer, Johnson? Yes, as far as each had a distinctive mark of genius and originality, which ranks high amongst the qualities of the human mind, and each was very deficient in the

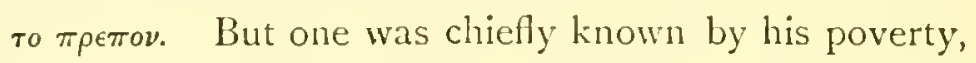
his misfortunes, and his wit; the other inherited riches, and might have set fortune's malice at defiance.

The strongest resemblance I can select is between the characters of the celebrated Earl of Rochester and the subject of this memoir; although in the points on which they differ the balance is favourable to the latter. Let us select the most prominent features, and see how far they tally and in what they differ :-

Rochester's person was well shaped, and no man showed more good breeding in society. Ditto John Mytton.

Rochester thought his constitution was so strong that nothing could hurt it. Ditto John Mytton.

"Rochester," says Bishop Burnet, "had a violent love of pleasure, and a disposition to extravagant mirth; the one involved him in great sensuality, the other led him to many odd adventures and frolics, in which he was often in hazard of his life." Ditto John Mytton. 
Rochester was turned loose into the world at a very early age, and so was John Mytton. The one entered the navy, the other the Seventh Hussars.

Rochester distinguished himself in an engagement. Mytton was never in one.

Rochester once made himself a mountebank. Mytton was always more or less one.

Rochester was drunk for five years continually. Mytton beat him by seven. *

Rochester "pursued low amours, in mean disguises." Mytton, in propriâ personâ, seldom pursued any other.

Rochester slunk away from his friend in a streetrow. Mytton would rather have remained to have been pummelled to death.

The Duke of Buckingham left it on record that Rochester refused to fight him. Mytton was never put to that test.

Rochester wrote libels in which he did not stick to truth. Mytton never said ill-natured things, much less published them.

* I am sorry to say one of his oldest friends, and a regular "pot-companion," made an affidavit-to serve a certain purpose-that he (Mytton) had been drunk for twelve successive years! I think it would bave been better that he had had recourse to the "Non mi ricordo." 
Rochester was eminent for the vigour of his colloquial wit. Mytton was deaf, and therefore could not shine in conversation. He dealt, chiefly, in practical jokes.

Rochester is mentioned by Wood as the best scholar of all the nobility. Mytton might have harangued an Athenian mob, if he had gone steadily through Harrow or Westminster School.

Burnet says, "Rochester played many wild frolics, which it is not for his honour that we should remember." Ditto John Mytton.

Burnet "touched as tenderly as occasion would bear" Rochester's faults. Mytton's spiritual adviser never touched his at all, if he could avoid it.

The good Bishop tells us, Dr. Balfour "drew Rochester to read such books as were most likely to bring him back to love learning and study." Mytton's tutor recommended the "Racing Calendar" and the "Stud Book"; nevertheless, he was well read in the classics, though perhaps not so well as Rochester was. The natural talent of each was excellent; each was generous and kindhearted; and "video ameliora, proboque; deteriora sequor,"-"I see what is better, and approve it; but follow what is worse," would have been a suitable motto for both. 
But Rochester was profane, which Mytton never was.

But I must draw this parallel to a close. Rochester was charitable to the poor and kind to his servants, so was Mytton-perhaps to a still greater degree.

Rochester made himself mad with drink. Ditto John Mytton. Was not the best of husbands. Ditto John Mytton. Trusted to a death-bed repentance. Ditto John Mytton. Promised to amend his life if he recovered from his severe illness. So did old Nick-at least so the story goes; but John Mytton never promised what he did not think he should perform. The one exhausted his life at the age of thirtythree, and the other of thirty-eight; and although both entered the vineyard at nearly the eleventh hour-for sackcloth and ashes suited neither of their tastes - they both died in penitence and prayer.

Mr. Mytton's amours, like Jupiter's, are too numerous for recital; yet, having been for the most part of the lowest description, they were chiefly injurious only. to himself, and had nothing to do with the heart.*

* One evening in a Chester race week he once managed to handcuff two girls on the pretence of trying on a pair of bracelets he had just purchased, and then left them in the "couples" to be laughed at 
But there was this peculiarity in them: I am quite sure Mr. Mytton never attempted the wife of a friend -no, nor even his mistress! Each would have been as safe in his hands as the beautiful captive was in those of Scipio, or the wife and daughters of Darius in the tent of Alexander the Great. Indeed I never heard of his laying siege to the virtue of any woman, but if in the market, he was sure to be the best bidder; and I fear I must own that he once or twice took it by storm. Some of his offers for capitulation, however, were truly ridiculous, though all in character with the man. For example, he once wrote a note to a certain celebrated singer, whom he had only seen for half-an-hour, at a musical festival, requesting the honour of an interview the next day, and enclosing a cheque at sight, on the Oswestry bank, for five hundred guineas! The lady - who all the world knows would have been quite satisfied with a ten-pound note-having luckily never heard either of John Mytton or the Oswestry bank, returned the note with its valuable contents. This reminds me of the following lines in a poem called "The Passions," a fair specimen of heterogeneous pathos :- 
"Human appetites how strong,

When love exults on fancy's fairy plains, Or kunger views the mutton at the fire!"

His popularity, independently of family associations, and recollections of ages long since gone by; the dashing personal character, and extreme and unaffected good-humour of the late Squire of Halston; together with his fox-hounds, his race-horses, his game, his wine, his ale, and many other things besides, rendered him extremely popular in Shropshire; and if he had but been possessed of a fair share of the $\tau o \pi \rho \epsilon \pi o \nu$, so much esteemed by the ancients, and so expressive of that exterior propriety of conduct, in the common intercourse of life, which the world is very unwilling to dispense with, he might have represented the county of Salop in Parliament as long as he liked to have done so ; it being the general opinion, that almost all the independent freeholders would have supported him. But this is the class of all others who dislike seeing a gentleman sink in the social scale; and when I was last in Shropshire, I was sorry to find my old friend's popularity was on the wane. His honour and his honesty were still unsullied; his heart was as kind as it had ever been; but the nearly constant 
state of intoxication in which he lived was, I could perceive, become somewhat insufferable to his oldest friends. Neither was this the worst. His associating himself with a late well-known sporting character, immeasurably inferior to himself in every possible point of view, gave the finishing blow; and who can wonder at it? for it must have been not only repulsive to good taste, but extremely mortifying to his friends, to see Mr. Mytton of Halston, with his natural talents and accomplishments, to say nothing of his connections, making a bosom friend of a man who had once filled the honourable post of a waterman to a hackney-coach stand! But there are moral as well as fabulous Actæons in this world, who are surely devoured by objects of their own choosing, and here we have an instance of it. In what way, however, can we account for a mind that had tasted the learning and elegance of Athens and Rome finding itself at ease in such an unsuitable association? Why, only by its being reduced to a state of perfect apathy and imbecility by the repetition of vicious and debilitating indulgences.

There is but one excuse for a man being almost perpetually intoxicated, and prostituting the reason 
of the man to the appetite of the brute; and that is, the attempt to divert grief which he has found it impossible to subdue. As a balm for wounds which can never heal, or under the accumulated pressure of pecuniary difficulties, the bottle will be resorted to so long as the world shall stand; and who can condemn the wretch that tries the experiment? But the subject of this memoir had not such excuses to plead for his excess in drinking, neither will I endeavour to find them for him. It was, however, to him the Circean cup-the bane of his respectability, his health, his happiness, and everything that was dear to him as a man and a gentleman; and can this be marvelled at? It is written of Hercules, that he acquired his immense strength by feeding on the marrow of lions; and how powerful must have been the stimulus of the almost unheard-of quantity of from four to six bottles of port wine daily, on that volcanic excitability of mind which was, not only by nature, Mr. Mytton's, but which had been acted upon, and increased, by a severe affection of the brain at an early period of life! Thus, then, although I offer no excuse for his drinking, his drinking-for men are tried by wine, says the proverb, as metals are by fire-furnishes excuses, I should rather have 
said apologies, for his conduct, inasmuch as his reason was, to a certain extent, lost in delirium, caused by the fumes of wine on an already somewhat distempered brain. Many of his acts were not the acts of John Mytton, but of a man, mad, half by nature, and half by wine, and I think his best and dearest friends are decidedly of my opinion.

From this account of its host, it may be supposed that Halston was a scene of general dissipation and riot. By no means. In short, I cannot bring to my recollection a single instance of being one of what may be termed a drunken party during my frequent visits to the house. But this is accounted for in more ways than one. The host had always the start of his friends, in the first place; and in the next, long sittings were not in accordance with his restless disposition. In the summer he would jump out of the window, and be off. In the winter, he was anxious to get to the billiard-table, which was always lighted up after coffee, for the amusement of himself and his friends; and here he was in his element. How then, it may be asked, did he consume that quantity of port wine? Why, this question is easily answered. He shaved with a bottle of it on his toilet; he worked steadily at it throughout 
the day, by a glass or two at a time, and at least a bottle with his luncheon; and the after dinner and after supper work-not losing sight of it in the billiardroom-completed the Herculean task. No wonder, then, that Alexander the Great has been called a "fool to him" in his Bacchanalian feats, at all events, he would have been a good playfellow for him at Persepolis; or that-as Cicero said of Piso-" his breath smelt like a vintner's vault." $\mathrm{He}$ is, however, a memorable example of the comparatively harmless; effects of very good wine, which he always had, andl just of a proper age-about eight years old-for, assisted by exercise, such as he took, it was many. years before it injured him. But, alas! wine at: length lost its charms; brandy - which he was a stranger to when I was last at Halston-was substituted, and the constitution of John Mytton, perhaps the hardest ever bestowed upon man, was not proof against that.*

But away, for a moment, with all recollection of

* It would be absurd to offer apology for these remarks, after the inquest on the body of my departed friend, which went the round of the newspapers. Besides, my object being to rescue his memory from imputations that lie against it, and, in some cases, not unjustly, it is in mercy-a dreadful alternative, I admit-that I exhibit him to the world. as both a drunkard and a madman. 
his ill doings, and let us move onwards towards his good ones; for it is a loss to mankind when good actions are forgotten. Be assured, reader, whoever you may be, that if all the kind, good, and charitable acts which poor, drunken, mad John Mytton performed, were placed in counterpoise to his bad ones, it would be more than man dared to say which side might kick the beam. At all events, like charity, they would weigh heavily to his credit; and it is consoling to his friends to reflect, that although great part of that fine property he once possessed has passed away to others, and the too liberal possessor of it is in his grave, those decds still remain with him. Man, it is true, is naturally a beneficent creature; but be the benefit he confers never so great, the manner of conferring it is the noblest part; and in allusion to my friend, let me illustrate this by one simple fact :-

When Mr. Mytton was at Calais, only a few months before his death, he chanced to be in a silversmith's shop, when a French soldier entered it, with a watch in his hand, which he said he wished to dispose of for the benefit of a sick comrade, who wanted some further comforts than a barrack afforded. On the silversmith objecting to the price demanded. 
Mr. Mytton threw down the money, and took up the watch. "Merciez, Monsieur," said the soldier, and something else besides, expressive of his grateful feelings. "Take this to your comrade, also," said Mytton, placing the watch in his hand. "Ah, Monsieur Anglais!" exclaimed the man-"que vous dirai-je?" *

Mytton replied, "Rien." $\dagger$ Remember, reader! this was not in his golden days, when money was as dross; it was one of the last acts of a noble soul, performed out of almost the last of the wreck of a splendid income.

The sentimental Sterne would have made a pathetic story out of this little incident, whereas I shall leave it to speak for itself; but Mytton felt what Sterne only made others feel: neither does the difference between then rest here. The one is said to have whined over a dead ass, and starved a living mother. The other would have laughed at the dead donkey-perhaps have ridden him to death-but he settled a handsome annuity on his mother! Such instances, however, are of very ancient date; Aristides practised what Cato only preached.

* What shall I say to you?

+ Nothing. 
A nother instance of his excessive philanthropy and over-generous, all-forgiving temper, occurs to me at this moment, which I may here introduce, though perhaps not without somewhat retrograding in my arrangement.

As I was passing through Shrewsbury, some years back, on my road to Halston, I saw a servant of his in the town, and asked him if he had accompanied his master. "I have left Mr. Mytton's service, sir," said the man. "How so?" observed I, with surprise, knowing him to have been a favourite servant. His answer was, that in an evil hour he had been induced to alter a figure in a bill of Mr. Lucas, the veterinary surgeon at Atherstone, who had attended one of his master's horses, and it having been discovered by the agent, he had been discharged. The morning after I arrived at Halston, I was told there was a person wanted to speak with me in the stable-yard, and there stood $\mathcal{F}_{0} \mathrm{~m}$, with a very sorrowful countenance. His object was to induce me to intercede for him with his master, and just as I was in the act of discussing the point, Mr. Mytton made his appearance. John protested it was the only instance of his dishonesty (and, indeed, the man bore an excellent character, having lived nine years 
previously with a clergyman in Shropshire); and that he should not have thought of committing it but for a certain ostler on the road, who persuaded him to it; and was about to proceed in the same supplicating manner, when Mytton seized him by the collar, and giving him one of his horse-like kicks, told him to go into the servants' hall and put on his livery again. John cared nothing for the kick; but on a very strong remonstrance from the agent-who indeed went so far as to say he should throw up his agency if such conduct were passed over-John was once more drafted from Halston servants' hall. Mytton's own notions of a good servant were somewhat peculiar. In once hiring a keeper he did not go so much upon character and experience, as the applicant's ability to thrash a certain sweep that was in the habit of trespassing in the Halston covers. A trial was accordingly agreed to, and the new man put upon the watch. In due course the sweep made his appearance, and after a long fight was well licked. The keeper's engagement was ratified forthwith, as the sweep was thoroughly satisfied-and the swecp was Mytton himself.

I conceive no one knew the limits of Mr. Mytton's natural talents. No doubt they were excellent; and 
if, instead of having been prostrated to the excess of wine, and its concomitant dissipation, they had been cultivated and improved to the utmost, they might have enabled him to have cut a figure in the senate or as a scholar. He read with unusual rapidity, and evidently retained what he did read; for his literary acquisitions were surprising, considering the life of tumult he had led. He had always a quotation at hand from a Greek or Latin author, and there was a conscious feeling of ability about him, which he was somewhat wont to display. But what say's the pcet?

\footnotetext{
"Without a genius learning soars in vain, And without learning, genius sinks again; Their force united crowns the sprightly reign ;"
}

and here was this union wanting. $\mathrm{He}$ also wrote his letters, to use a sporting figure, at the rate of twenty miles in the hour, generally at his dinner-table, sending them out by his butler to be sealed, and very often to be directed, for he never had a secret in his life; and the letters he received remained for general inspection. I regret not having one of them to transcribe, but his off-hand addresses to his constituents, during his first contest for Shrewsbury in 1819 , were particularly neat and appropriate, and were sent to the press before the ink with which they were written 
was dry. How much, then, is it to be lamented, that a man who had such resources for spending his life in the pleasantest, as well as the most honourable occupations, should have thus abused his mental powers, and subjected himself to misery of any kind beyond that which is common to all; and that repose and retirement, the secret wish of mankind, should by him have been considered valueless, if not irksome!

I may here reproduce some specimens of $\mathrm{Mr}$. Mytton's off-hand style of writing, in two of his addresses to the Freeholders of Salop, on his last unsuccessful attempt to become one of their representatives in 183I; but they fall far short of the others both in matter and style. In fact, they bear evidence of a mind in decay, and sinking with the general wreck. 


\section{ADDRESS (No. I). - I $8_{j} \mathbf{I}$.}

"To the Freeholders of the County of Salop.

"Gentlemen,-Domestic affliction of no slight or common nature has latterly limited my intercourse with you. My wishes for the prosperity of my native county have ever in absence held their usual sway. Having once had the honour of representing your County Town in Parliament; feeling that various avocations precluded the conscientious performance of my duty to my Constituents, I declined the representation at the dissolution of that Parliament. I have now no wife-no family-no hounds-no horses(some will say, no steadiness of purpose)-but feeling that I can devote myself to your service, should you honour me with your support and confidence, I venture to offer myself to your notice as a Candidate for the County, totally unshackled by prejudice or otherwise, and a strenuous advocate for Reform.

"Relying upon the strength of the cause I shall advocate, I throw myself upon your favour, and shall 
assuredly take the sense of the County. I shall look to the vote of every Independent Freeholder. With. out making further professions,

"Your faithful friend and servant, "JOHN MYTTON.

** "Peculiar private business may prevent my personal attendance, but I look upon it as a favourable omen, knowing that when absent you are best remembered.

"May 4 th, I8 8 r."

\section{ADDRESS (No. 2).}

"Friends! Men of Salop,-In declining longer to continue the unequal contest in which 1 am embarked, I trust you will not consider my word forfeited. I have (and I trust with your approbation) come forward to assert the rights of free men, and to break the bonds of tyranny asunder!

"Show yourselves the proud Salopians!

"Gentlemen,-I pledge myself to come forward at the next Election for this great County, which I have already shaken to its foundation by my attempt 
to assert its independence, which shall be maintained with the vigour of a tiger and the courage of a lion ! Let your voice, as the falls of Niagara, rush in force, and with the greatest velocity bear the fragile barks of corruption (which of necessity must be destroyed) to some land, perhaps at present unknown, but let them not be borne to the shores of Britain.

"I have asked no advice,-much has been offered, and maturely weighed, during this contest; but, Gentlemen, did I not feel myself capable, upon reflection, of duly considering any subject which may fall under my notice, I should feel myself unworthy of looking for your approval. I came forth uncalled for, unprotected by any great interest ; I recire from this contest in confidence of victory in future; I adopt one line of conduct, and from that I will not swerve.

"My thanks for the unbought Votes of nearly Four Hundred Honest Men, are gratefully tendered to them; - the cause of Freedom in our devoted County will assume a brighter complexion.

"Gentlemen,-You will find me at my post the first moment that a Reformed Parliament will allow it. My reception among you has indeed been proud; I beg to thank you for that exhibition of 
sincerely popular feeling in my favour, so strongly and so universally evinced.

"I tender my best thanks to the Ladies, for the smiles I have witnessed. Let me now entreat of you to allow the proceedings of Monday to pass without riot or disturbance, as it would only entail disgrace upon the cause $I$ advocate.

"I am, Gentlemen,

"Your Servant, "JOHN MYTTON.

"Shrewesbury, Mfay 14th, 1 $S_{31 . "}$

Nor are the two following squibs by any means amiss. But Mr. Mytton's chance to represent his native county was slight indeed, having only polled 3 II votes; the "proud Salopians," much to their credit, not by any means approving of the degrading association with which they perceived him to be leagued. There was a time, as I have already said, when lic would have cut a very different figure on the poll. 


\section{"MYTTON AND BEARDSWORTH.}

"Arrived last week in this Town, an old brokendown Racer, from the 'Union Repository,' Birmingham, with two BLACK LEGs, fresh fired and blistered. He is attended by an old Groom, grown grey in the Service, who has jockeyed him, unBRIDLED, through many unlucky courses, and who, having lately considerably Lightened his Weight, flatters himself he will REFORM his style of running. The old Horse starts for the County Stakes this week; to be run for on the Quarry Course. The odds are 500 to I against him; nevertheless the Brums (i.e., Brumnagems) are in high spirits, he being backed by a few respectable branches of the Мов-ility here. Gentlemen are recommended not to go too near the Horse, he being vicious and apt to kick. It is understood, that should he not wis, the Proprietor will take the Horse back with him to Birmingham, thinking to work him in a SLow CoAcr and 'black jobs,' until he is fit for the knacker.

\section{"Shrezesbury, Mray 9th, 18 3 1."}




\section{“A REFORM CANDIDATE'S SPEECH.}

“Yes! gentlemen, upon my soul, I thank you much for what you've done;

Though at the bottom of the poll,

I've too much 'Botron' yet to run.

"I told you all, when first I came,

You'd not find me the man to shirk; -

To play on-now I've lost the game,

Does seem like devilish up-Hill work."

“Reform's my vessel, mann'd by Brums, Who hoist ME for their 'Union Jack ;'

She'll fight till Captain Beardsworth comes

To steer her on some other tack.

"Yes! he has nail'd me to the mast,

Without a rag of CANvass going ;

And though we ARE capsized at last,

The Captain 'raised the wind' that's blowing." +

* Sir Rowl.ınd Hill, Bart., was the successful candidate.

tIt is said that Beardsworth appeared on the hustings with a banknote, of large amount, pinned on his breast. 
It is a great accomplishment to be able to tell a story well, but here Mr. Mytton did not succeed. In the first place, his sense of hearing was deficient, a great disadvantage in socicty. In the next, it was often difficult to determine whether he were in earnest or in jest, so fond was he of acting a part in the comedy of life. Again, he was very epigrammatic in his discourse, his sentences containing few words, and often leaving his hearers to guess what he really meant. All, however, was in the essence of good-humour; and a more inoffensive companion, in the strict acceptation of that term, no man with his flow of spirits could possibly be. If, in the moment of convivial mirth, he let slip a word which he feared might wound the feelings of any person, he instantly made reparation, nor would he rest satisfied until it was fully acknowledged and atoned for. It is warmth of heart like this that distinguishes the friend from the companion, and assimilates friendship to love. As to his politics, although he once was in Parliament, it would be absurd in me to attempt to decide what they were, for, during all the years I was acquainted with him, I never once heard him give an opinion upon the subject. It always struck me as not one of the maddest of his 
own acts, but certainly of his friends who encouraged him, to spend ten thousand pounds to obtain a seat in Parliament, in which he is said to have only sat half-an-hour, and to the duties of which he was by nature and habits utterly unfitted. I have reason, however, to believe-for I never interrogated himhe was what is termed a Church-and-king man; in other words, at that period, a Tory. But on this subject he was also full of his jokes. For example, he had a famous race-horse called Anti-Radical; "But," said he, when speaking of him, "I always call him Radical when he runs at Manchester."

Without appearing to care about it, or ever boasting of his success, Mr. Mytton was the best farmer in his part of the county, occupying between three and four hundred acres of land. Strange to say, at one of the Shropshire agricultural meetings he gained every prize for clean crops of grain, save one, a field of barley, his claim for which was rejected from a cause highly typical of the man,-It was found to contain "wild oats!" As may be supposed, the report of the judge was the subject of much merriment to the company. His planting, as I before observed, was on a still larger scale, his object liaving been two-fold; first, to replace the fine old timber, 
which he must have been aware would one day or other fall under the axe; * and, secondly, to form cover for the game, which, of course, he was resolved should exceed that of any other man in the country, and no doubt it did.

As a general sportsman, few made themselves more conspicuous than Mr. Mytton did. He was many years a master of fox-hounds (having kept a pack of harriers from his boyhood), but his fox-hounds were not of a very high character. In fact, to produce perfection in a kennel requires qualities the very reverse of his, namely, circumspection, perseverance, and patience. The establishment, as might be expected with himself at the head of it, was on a fully competent scale; consisting of two distinct packs of hounds, and from tiventy-five to twenty-eight horses. On Mr. Cresset Pelham relinquishing them, in I $S_{1} 7$, he commenced hunting the Shropshire and Shiffnal (now called Albrighton) countries five days a week; and continued to do so, with a fair share of sport, until the close of the season I 821 inclusive, making five seasons in all. His huntsman was John Crags (killed by a fall

- A well-known auctioneer at Shrewsbury said of him, at a very early period of his career, with a fatal gift of prophecy, "He'll put the haxe to the hoaks and the hash." 
from a restive horse in the stable-yard at Halston), assisted by Edward Bates, son of Sir Richard Puleston's huntsman of that name, and Richard Jones, both very excellent horsemen, and good men in their places. When he had the Shiffnal country, which he hunted alternately with his own, his kennel was at Ivetsy Bank on the old Chester Road, and he used frequently to ride from Halston to covers even beyond Ivetsy to meet his hounds, and return home to dinner,-making upwards of eighty miles on the road, and he was known to do this on two successive days. But the best runs Mr. Mytton's hounds ever had were from covers in his own neighbourhood, with wild travelling foxes that came down from theWelsh hills. His first pack showed fair sport, and were not more unsteady than others I could name. He either sold the greater part of these hounds, or, more likely, lost them in a match at billiards with an Irish gentleman. Mr. Mytton subsequently purchased another pack of fox-hounds from Mr. Newman, of Hornchurch, Essex, which he hunted himself, about Halston, for several successive years, making up, by foxes purchased in London, for the confined country to which he was restricted. I remember, during this second term of it, once visiting the Halston 
kennel in company with Sir Bellingham Graham, where we saw about thirty couples of hounds. What to call them I know not: some were as big as my yard-dog, and here and there a neat little bitch; and whether to call them fox-hounds, harriers, or staghounds, would take a better judge than me. This was all very well; but we were next favoured with another sight, not quite so favourable to Sir Bellingham. This was no less than five brace of foxes to be turned out before this nondescript pack, a brace of which I subsequently saw "shook" before them. But the preparation for this business was not so bad. In the evening, as we were sitting over our wine, the butler announced that Mr. Tinkler, the studgroom, was in waiting. "Send him up," said Mr. Mytton, and Mr. Tinkler appeared.

Tinkler. "What horses will be wanted to-morrow, sir ?"

Mr. Mytton. "All."

Tinkler. "No, sir, not all, surely?"

Mr. Mytton. "Every one."

Tinkler. "Not the little grey horse, sir? His back gets very narrow."

Mr. Mytton. "So much the better. I hate a fat horse." 
Tinkler. "Not the brown horse you had from Sir Bellingham? His legs begin to get very round."

Mr. Mytton. "That is the very reason why I will ride him, as it will make them fine."

Tinkler. "Not the Hit-or-Miss mare? You will want her for the Cheshire."

Mr. Mytton. "It will put her in wind."

Remonstrance was in vain. Every horse was saddled, and the Squire, his three whippers, with Tom Whitehouse, his jockey, were all mounted on the best horses in the stud.

I cannot describe our arrival at the covert; I cannot speak of the hound that "spoke to him in the gorse;" I cannot even attempt to describe the crash when he broke from the covert; but-from the inside of a wicker basket with a lid to it-(oh! how tame, how languidly, does my pen move over my paper as I write it!) - away sneaked as fine a fox as ever wore a brush, and certainly afforded us a very fine run of an hour, when he fell a victim to the pack, which, I must say, hunted him well.

Nothing is to be done in Shropshire without a luncheon; but, on this day, we had two-first, at the inn at Ellesmere, after our run; and, secondly, at the house of a very respectable yeoman, by the name of 
Wynne (of Cricketh), where the second fox was in waiting. The second luncheon, however, saved this fox's life; for, after the usual law was given him, and I was in the act of mounting my horse, Mr. Wynne came out to me and said, the Squire proposed one other bumper toast, which he hoped I would return and drink. The hounds were then laid on; but though they were sober, the faculty of smell had deserted them, and they never touched upon their game. The exertions of their huntsman, the Squire himself, however, were great. Mounted upon Magnet, with his horn in his mouth, and at three parts speed, he made his casts with the rapidity of a Shaw : but one peculiarity attended them. If the fence into one field was larger than that into another, that field was preferred-not as most likely to hit off his fox, but as most likely to floor some of his field, who, with his three whippers and Tom Whitehouse, were hard at his brush. As the pace was quick, and the country heavy, I was beginning to calculate upon how long the nags would live without a check, when an accident occurred that put a stop to all. A hare got up in view, which every hound followed into Sir Edward Kynaston's plantations, and thus ended the morning's sport. When he again gave up, these hounds were 
sold for somewhere about the value of their skins; nor was this to be wondered at, when we remember the tricks that had been played with them.

I could never discover whether or not Mr. Mytton was, at heart, a sportsman-that is to say, whether or not he enjoyed seeing his hounds at work, beyond the mere pleasure any Master might feel at the finish of a good run; when, although he himself had little enough of that infirmity in his composition, his vanity might be flattered. I never heard him cheer an individual hound when drawing or in chase; nor, with the exception of Hudibras, had he any favourite hound, as most Masters have; neither did he know the names of all the hounds in his kennel. This last assertion, however, requires some qualification. He would tell his friends he did not know their names, but whether such was really the case I cannot take upon myself to say, knowing his disposition on trifling matters to disguise his real sentiments.

As a horseman I need say little of Mr. Mytton, his merits having been proclaimed in every county in which he had hunted. In fact, taking him at everything, he had not many equals, and very few superiors in the saddle, for he could ride over a course as well as over a country. His prodigious strength was 
of great service to his horses, in proof of which they very seldom tired with him; and, making allowance for the seemingly impracticable fences he would ride at, he got but few falls. Considering his hard usage of them also, he was fortunate in his stud, several of his horses lasting many seasons; and his famous little horse, Baronet, carried him nine seasons with hounds, after he had used him as a charger in the Hussars! He had his portrait painted, on this horse, having his horn in his hand, and the hound Hudibras at his side. Baronet was a mean-looking horse, with only one eye; but Nature had made amends for that in giving him more than one life, or he would never have survived the last seven years that he was in Mr. Mytton's possession. He may be said to have been as stout as steel; and if there was rank amongst brutes, this Baronet should have been raised to the peerage. Having, however, mentioned this gallant animal in connection with his hard-riding master in my "Crack Riders of England," I will here quote what I there said of both. In speaking of the master, I say "There is no man better entitled to a place amongst hard,-aye, desperate-riders to hounds than Mr. Mytton is, and a welter weight too. But how is it that he can come under the latter denomination who, 
ten or twelve years back, was riding amongst the gentlemen jockeys under twelve stone? The question is best answered by the fact of his having been, by the aid of excess in good living, upwards of fifteen, with his saddle, for some years past; and I think Sir Bellingham Graham will confirm the truth of my assertion, that he was nothing short of that weight, on his capital Hit-or-Miss mare, when he so distinguished himself in that famous run with his, Sir Bellingham's, hounds, of an hour and forty minutes, from Babinswood, in Shropshire. But it has not been in this run, nor in that run, in one country or in another country, that Mytton has made himself signal; and yet I might hazard an imputation on my veracity were I to recount all the extraordinary deeds of this most extraordinary man, in various situations with l:ounds. Indeed, adding the hazards for his neck that he has encountered in the field to those to which he has subjected himself elsewhere, the most extraordinary thing after all is, that he is at this moment in existence. However, confining my remarks to his riding, I am bound to pronounce him one of the most daring horsemen that ever came under my eye ; and I must likewise add that, all things considered, he has had fewer falls, and tired fewer horses in chase, than 
his larking and desperate system of crossing countries would warrant the expectation of. But this has been attributable to the immense muscular powers of the man; to a sort of iron grasp by which he holds his horses in his hand at all times, and upon all occasions, which, let your slack-rein gentlemen say what they may, is no small support to a horse going his (Mytton's) pace over a country, and particularly over the uneven surface, the deep ditches, and blind grips of his own county, Shropshire. Indeed, when I last met him, I asked him whether it had ever been his fate so to tire a hunter as not to be able to ride him home, when he declared he never recollected having done so. As to the height and width of fences which have been ridden over by him, I repeat I am afraid to recapitulate them; but I have very respectable attestation to my having once measured a brook * that he rode Baronet over, in cold blood, in my presence, on our way home from hunting, and found it exceed, by some inches, nine yards from hind-foot to hind-foot! He afterwards backed Baronet to clear nine yards over hurdles placed at some distance from each other; but he performed the task so often

- The Perry, which runs through the Halston estate. 



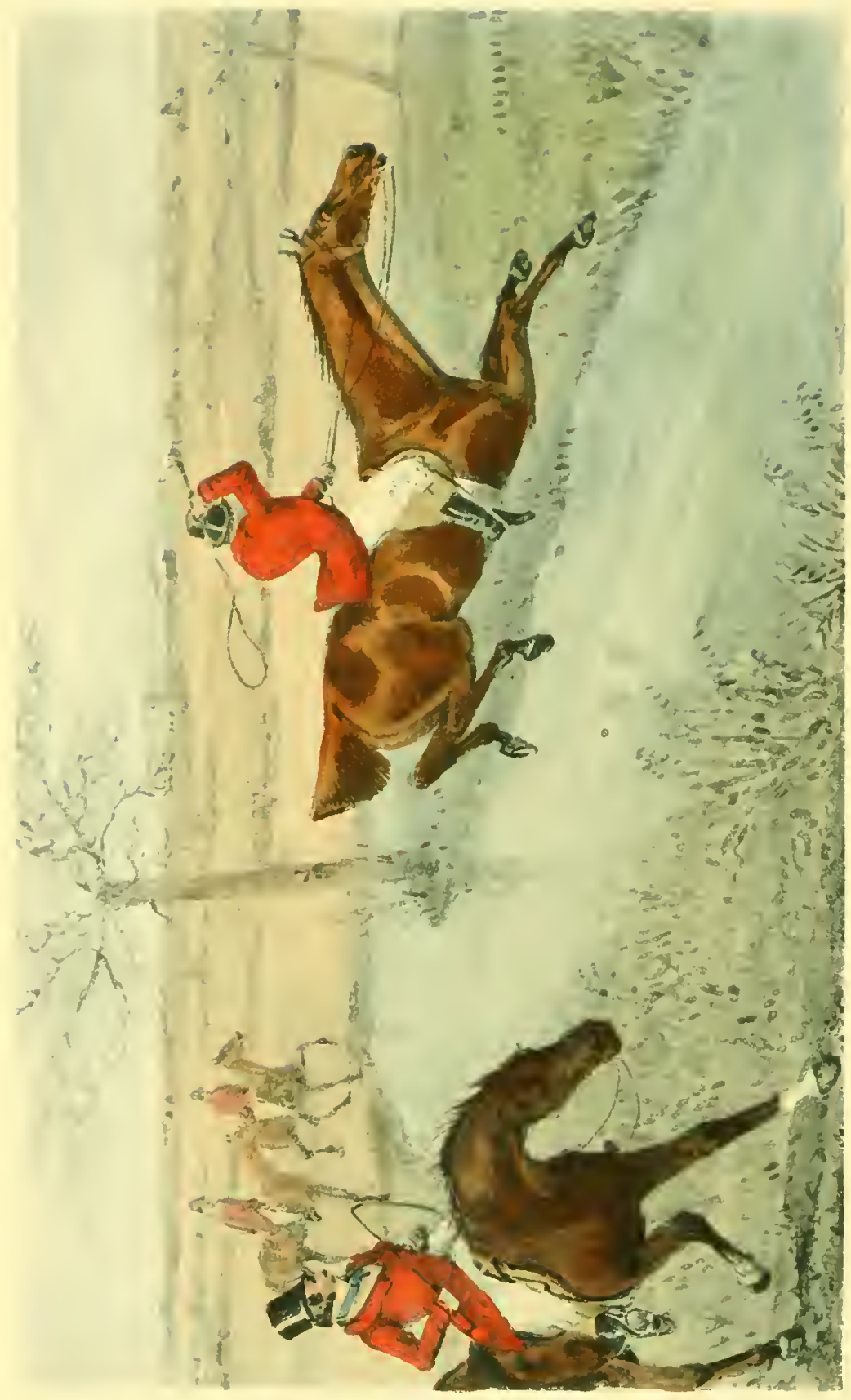




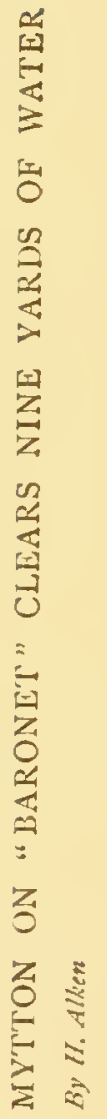



with him before the appointed time, that the horse then refused it, and lost his master's money. In Lord Bradford's Park he cleared one of his Lordship's deer-hurdles, upwards of six feet high ! and, what is more surprising, he covered the space of eight yards in length at the same time. This was accomplished on a horse called the Hero, which he purchased of me for 500 guineas, and was the same that leaped the gate with him in Mr. Jellico's grounds in Shropshire, the height of which was seven feet. But far from pleasing reflections are the result of looking back upon these brilliant feats of horsemanship, rarely excelled by any one. On the contrary, we cannot help lamenting that a person so gifted to shine in the field, as $\dot{\mathrm{M}}$. Mytton proved himself to be, should not have taken more care to preserve, unimpaired, the almost unequalled natural powers which he possessed, -so essential to the figure he made."

Nothing need be better than the shooting at Halston was ; every species of game having abounded, as the following facts will prove. The average annual slaughter was, - twelve hundred brace of pheasants, from fifteen hundred to two thousand hares, partridges out of number! We have turned into the preserves after luncheon, where the phea- 
sants were as thick as sparrows at a barn door, and the hares running about like rabbits. The team consisted (not of highly broken pointers, but) of four keepers and three stable-bnys, who kept singing out as the pheasants got up,- " cock-hen -cock-hen-cock-hen." Pheasants and hares were of course slaughtered in abundance, but don't let us call this sporting. There was also a good deal of wild fowl, and very excellent fishing. $\mathrm{Mr}$. Mytton always made a point of killing fifty brace of partridges the first day of the season with his own gun; and I was once at Halston when he killed that number further on in the year. A neighbouring gentleman had betted him fifty guineas against the performance, but paid forfeit over night. This, however, did not satisfy the Squire. His fame as a shot was called in question, so he went forth with his keepers, and performed the task in about six hours!

Barring Scotland, few grentlemen had better moors than Mr. Mytton had; and when I say that the annual income of his Merionethshire estate, on which they were, was Sool., and that it consisted of little less than sheep-walk, its great extent may be imagined, and, consequently, the extent of the moors. 
Thirty brace of grouse was the average daily amount bagged during his annual visit to Mowddy-or, Mouthy, as it is pronounced-where he had comfortable accommodation for himself and three or four friends. The right of free warren likewise gave him liberty over his neighbour's property, to a certain extent, and Mowddy itself is one of the few manors to be found in North Wales. The fishing here is likewise of the first description, and the mountain scenery not to be surpassed in the Principality. But alas! although the mountains will stand fast till time shall be no more, this ancient patrimony has passed into other hands.

But to return for a moment to Halston, and the feats of the trigger of the late owner of it and his friends. Amongst them, the following may not very easily be exceeded. His brother-in-law, Mr. Walter Giffard, of Chillington, Staffordshire, afterwards Master of the Albrighton fox-hounds, and himself, took the field at eleven oclock in the forenoon of a short and dirty winter's day, and between that hour and the dinner-hour they bagged 600 head of game from their own guns! To decide a match of 100 . guineas a side, he and Mr. Giffard, on another of the "short days before Christmas," killed 430 head 
of game, $33 \hat{3}$ of which were pheasants; and their tivo opponents, 424 head, all in the Halston preserves. On another occasion, an intimate friend of his and mine, together with himself, killed a head of game every' three minutes for five successive hours! I state this "in verbo saccrdotis," so that the fact may be relied upon, but I withhold the reverend slaughterer's name.

It always appeared to me, however, that racing was more Mr. Mytton's passion than either shooting or hunting; and could he have been divested of that destroying spirit which accompanied him, the might have cut a very conspicuous figure on -what may be called the country turf. He had the courage to purchase good horses,-for example, he gave three thousand guineas for Longwaist-and his never-failing memory enabled him to measure their ability by that of others in a manner that turned to his account. Previously, indeed, to the loss of his trainer and rider, William Dunn, who was killed by a fall in riding one of his horses at Chester, he had his full share of success; but it appeared to forsake him gradually after that period. The

- This was in 1822, when Dunn was riding a three-year old colt called Mallet. The famous jockey William Scott rode, and also fell, in the same race, but sustained no material injury. 
fact was, Dunn was not only an excellent trainer and rider, but he had some power over his master to restrain his running his horses to a stand-still, which he would do if left to his own discretion, and more for the sake of showing sport than from desire to win money. The sideboard at Halston exhibited thirteen gold cups, besides two silver ones, several of which were the trophies of one horse-the celebrated Euphrates, who, like one of the old sort (now become very scarce), continued running and winning to his thirteenth year! The expenses of his stud, however, must have been enormous; not only by consequence of its number, but his subscriptions to stakes amounted to an immense annual sum. He seldom refused to subscribe to any that were put before him, and the name of "John Mytton" often appeared as many as six times to the same race. Of the science of breeding race-horses he knew little or nothing; and the richness of the land at Halston proved a fatal obstacle to success.

His good nature and kind-heartedness accompanied him everywhere, and particularly to the race-course. He often started his horses without a prospect of their winning, for the purpose of affording sport; overruling the objections of his trainer by saying, "'Tis 
a pity the country people should come so far from home and not have some fun."* In fact, that class of persons always built on diversion when "Squire MIytton's" horses were on the turf, and consequently, with them, the popularity of their owner had no bouncls. "Which is he?" they would cry out to one of their friends that knew him. "That's he-that's Mytton," the friend would reply. "Dang it!" you would hear a Staffordshire potter or a Walsall nailor exclaim, "ha looks loike a good" un; they tells me he can foight nation well."

Before he became too heavy, my friend occasionally rode among the gentlemen jockeys $†$ of the day; and here "John Mytton" appeared again, for, strange to say, he did not like to see an intimate friend win, although he himself could not win. I had a rare specimen of this unaccountable frolic in my own person once, when riding in the same race with him at Lichfield. He knew he himself had no chance to win, but was determined I should not; and, by making several runs at my horse, caused him to

- At Chester, he once actually went to his stable and fetched a horse down to the course himself, which his trainer had not prepared to run, and, mounting his jockey at the post, won the prize contended for.

+ Mr. Mytton's colours were green and white, with a black cap. 
break away with me in the race, and the little chance I had was lost by it. I say "the little chance," because, although I defeated seven of eight horses that started against me, by at least twenty lengths, the ninth came up and won cleverly at the last. This proved to be the famous Habberly, who was instantly purchased by Mr. Mytton for two hundred guineas, but who had never started or been heard of before that day. He was called and entered as a cocktail; but, as his subsequent running proved, Eclipse was not more thoroughbred than he was; and no doubt the original owners of him knew it.

Let us here take a cursory review of his start and progress on the turf. It appears that he entered upon its fascinations at the earliest possible opportunity, viz., on attaining his majority in I 8 I 7 . In the book calendar of that year there are three horses attached to the name of "John Mytton, Esq.," the names of two of which, "Hazard" and "Neck or Nothing," are highly characteristic of the man, and especially so at the commencement of his perilous career on this slippery ground.

He made his début at Oswestry on the $23 \mathrm{rd}$ of September of the said year, on which day both the 
above-named horses ran (Neck or Nothing breaking down); also a third, called Langolee, an Irish horse, purchased by him when in France, and which lasted him many years as a whipper-in's horse, and also was used in the stud, to get hunters.

In the following year, $I S I S$, his name appears in the Calendar as owner of the following horses: Langolee, Leopold, Pranks, and Jupiter.

Langolee walked over for a hunter stakes, and beat Mr. Jones's Kill-Devil in a match at Shrewsbury in September, which was his blooding of success on the turf. This year his horses ran at Oswestry (where "Captain Mytton" gave $50 l$. to be run for by members of the Oswestry Yeomanry Cavalry), at IVrexham, Holywell Hunt, and Tarporley Hunt, over the new course on Delamere Forest.

In 1819 he had Jupiter, Sybil, Tambourine by Cervantes, Dot-and-go-one, Tattoo, Anti-Radical, Fox-Huntress by Sultan, and Single-Peeper, in his racing-stable; during which year, however, he experienced the want of success peculiar to most young turfites.

In I $_{20} 0$ his string of horses were considerably lengthened. In addition to Anti-Radical and Leopold, he had gr. f. by Fitzjames, Mandeville, Theo- 
dore Majocchi (late Handel), Halston by Langton, Claudius, Chance, The Polacca, George the Third, Brunette, Paul Potter, and Victorine.

Anti-Radical won him some good stakes at Chester, Warwick, Lichfield, Oswestry, Tarporley, and the gold cup at Manchester.

Mandeville won the gold cup at Nantwich and Nottingham, also 100 gs. at Manchester.

Halston won four stakes, value $200 l$.

1821. Victorine, b. c. by Aladdin, Paul Potter, The Chancellor, Halston, Doctor, Anti-Radical, The Ruler, Vade-Mecum, George the Third, Shrewsbury, Hudibras, Queen Caroline, Habberley, SinglePeeper, Mandeville, Claudius, Theodore Majocchi, were in his racing-stable.

Halston won the gold cup at Nottingham, also stakes at Worcester and Chester, value $\mathrm{I} 35 \mathrm{gs}$.

Anti-Radical again carried off the gold cup at Manchester, also the Palatine stakes and the gold cup at Burton; and Habberley, then called Acastus, said to be by Shuttlecock dam by Gayman, gleaned some good things at the Anson Hunt, Manchester, Hereford, and Shrewsbury.

Mandeville also won four times, the stakes amounting to about $200 \mathrm{gs}$. 
Claudius won the gold cup at Cheltenham.

1822. He had Claudius, Mallet, Habberley, Netthe, The Ruler, Enterprise, Queen Caroline, Halston, Mandeville, Theodore Majocchi, Anti-Radical, Circe, Vade-Mecum, Banker, two br. colts by Filho da Puta, Jovial, ch. m. by Milo, ch. g. by Young Alexander, Paradigm.

Habberley won the Billesden Coplow stakes at Croxton Park, the Half-bred stakes at Chester and Manchester, 40 gs. at Shrewsbury, and So gs. at Oswestry.

The Ruler by Rubens won the Sherwood stakes at Nottingham and 6ol. at Manchester. He was induced, by a flattering account given him by the owner of a trial, to offer $500 \mathrm{gs}$. for this colt at two years old, worth about as many shillings.

Halston started ten times, and only won $50 \%$ at Oswestry. Mandeville won 65 gs. at Nantwich; Anti-Radical 60 gs. at Cheltenham. Banker by Smolensko, after he became Mr. Mytton's property (having been purchased this year of Mr. Charlton, with whom he had won the cup at Winchester), won the cup at Abingdon, and 70 gs. at Shrewsbury. One of the Filho colts won $75 \mathrm{gs}$. at Lichfield. Jovial by Golumpus won the Cocked Hat 
stakes at Shrewsbury. The ch. mare by Milo the silver cup at Oswestry. The gelding by Young Alexander the Cocked Hat stakes at Oswestry; and Paradigm by Partisan the Wellington stakes at Basingstoke.

IS23. IVe find Habberley, Banker, Enterprise, Whittington, Euphrates (purchased of Mr. J. Dilly), Libertine, Ostrich, Clansman, Paradigm, Anti-Radical, br. c. by Bustard, Sir William purchased of Mr. Beardsworth), Cae Avon, The Devil, placed after his name.

Habberley won the Boston stakes at the Anson Hunt at Lichfield. Banker won 60/. at Buxton. Whittington, by Filho, won 235\%. at Chester, Shrewsbury, Walsall, and Stafford. Euphrates, then seven years old, by Quiz, won the King's plate at Chester, and the gold cup at Worcester. Ostrich, by Bustard (son of Castrel), won ${ }_{1} S_{3}$ gs. in two sums at Knutsford and Warwick; and the colt by Bustard won 9ol. in two sums at Oswestry and Holywell.

IS24. He had Habberley, Euphrates, Ostrich, Oswestry, Berghill, Comte d'Artois, Whittington, and Ludford.

Euphrates won the gold cups at Cheltenham and Lichfield, and the Oxfordshire stakes at Oxford. 
Oswestry, by Filho, won 100l. at the Pottery, 75 l. at Buxton, and the Mostyn and the Halkin stakes at Holywell. Berghill, by Bustard, won the Ludford stakes, and $150 \%$ in three sums at Ludlow, Shrewsbury, and Wrexham. Comte d'Artois, by Bourbon, won 70 . and the gold cup at Worcester, the gold cup at Hereford, and the Hawarden Castle stakes at Holywell. Whittington won the gold cup at Oswestry, the gold cup at Wrexham, another at Stafford, and 345l. in different sums; while Ludford, by Manfred, won 50l. at Holywell.

I 825. Elizabeth, Cara Sposa (late Miss Fyldener), Ludford, Oswestry, Comte d'Artois, Louisa, b. c. by Amadis, Euphrates, Comrade, b. f. by Blucher, b. f. by Cannon Ball, b. f. by Ambo, Flexible.

Ludford won $100 \mathrm{gs}$. at Oswestry and Holywell. Oswestry won the gold cup at Shrewsbury and 55l. at Burton. Comte d'Artois 6ol. at Shrewsbury. Louisa, by Orville, 225l. at Chester, 70 gs. at Nottingham, and $100 \mathrm{gs}$. at Derby. Euphrates won the gold cups at Newton, Worcester, Lichfield, Wolverhampton, and Oswestry; also 50l. at the latter place. Comrade, by Partisan, won 60 gs. at the Pottery. The Blucher filly 225l. at Holywell, and 50l. at Wenlock. The Cannon Ball filly 5ol. at Oswestry. Flexible, by 
Whalebone, 120l. at Shrewsbury, 50l. at Oswestry, $210 l$. at Holywell; a pretty good year's work.

I826. Flexible, Whittington, Fisherman, Euphrates, Balloon, Longwaist, Bowsprit, Louisa Ashbourn, ch. c. by Sam, b. c. by Amadis, Harriet Wilson, Lark, and Comrade.

Flexible won the Darlington cup at Wolverhampton, and $70 l$. at Cheltenham. Whittington $60 l$. at Chester. Euphrates carried off the gold cup at Lichfield, the gold cup and 50l. at Oswestry, the King's plate and 70 . at Chester. Longwaist, by Whalebone, won the gold cups at Newton, Buxton, Worcester, and Warwick, also 40l. at Chester. Bowsprit, by Rainbow, won 50l. at Ludlow. Ashbourn, by Cheshire Cheese, 60l. at Oswestry. Colt, by Amadis, 23ol. at Nottingham; and Harriet IVilson, by Manfred, $40 l$. at Shrewsbury.

1S27. Fisherman, Flexible, Lechmere, Ellesmere, another Halston, by Banker, Euphrates, Mexican, Lark.

Ellesmere, by Filho, is the first winner of the above lot, viz. of $125 l$. at Nottingham. Halston won $275 l$. at Chester, 175l. at Ludlow, and the Chillington stakes at Wolverhampton. Euphrates won the gold cup and 50i. at Oswestry, and the King's plate at Lichfield. Lark, by Rubens, 55l. at Nottingham. 
1828. Spruce, Hedgford, Euphrates, Halston b. c. by Master Henry, The Crofts, br. f. by Filho.

Spruce, by Skim, won 10ol. at the Anson Hunt. Hedgford, by Filho or Magistrate, the cup and $50 l$. at Chester, and 50l. at Nottingham. Euphrates won the cups at Ludlow, IVorcester, Oswestry, and Wrexham, also the King's plate at Chester. Halston, the Palatine stakes at Chester, $100 \mathrm{gs}$. at Newton, $75 \mathrm{gs}$. at Worcester, $200 \mathrm{gs}$. at Burton, the Avon stakes at Warwick, 155 gs. at Oswestry, the Taffy and Pengwern stakes at Holywell.

1S29. The numbers were considerably reduced. Brown filly by Filho, The Crofts, Halston, Hedgford, and Euphrates, being the whole of the horses he had in training.

The Crofts, by Whalebone, won I25\% at Oswestry, and 5ol. at Wrexham. Halston, the Tradesman's cup at Chester, the cup at Knutsford, 350l. the Pengwern stakes, and is 5 l. at Holywell. Hedgford, 63l. at Chester. Euphrates the gold cups at Ludlow and Wolverhampton, and the King's plate at Lichfield.

1830 . This year brings us to a close, Halston and Hedgford being the only race-horses he had left; the former winning 5ol. at Holywell, and the latter the 
Cheshire stakes at Chester, 110 . at Newcastle, and 50l. at Wrexham.

I find I must here retrace my steps a little, and this for two reasons. First, I shall follow the good example set by himself in bearing testimony to the worth of a good servant; and, secondly, shall transcribe a letter of his own, which sets forth the writer of it in his true character. It will be recollected I asserted that Mr. Mytton's success on the turf somewhat declined after the death of his trainer and rider, William Dunn. Let it not be supposed, however, that I intend in the least degree to disparage the good conduct or abilities of his subsequent trainers or riders, but to impute it to that "tide," as Shakspeare calls it, in every man's affairs, wherein fortune has a share, which, despite of everything and everybody, will now and then set against him. I have good reason to believe that Mr. William Dilly and my old servant, Thomas Horsley, did all that could be done for Mr. Mytton as trainers of his horses; and the fair ability of his jockey, Whitehouse, is very generally acknowledged. His master's opinion of him, however, is here unhesitatingly given in one of the prettiest letters, if I may use such an epithet, that I ever perused. 
"To the Editor of the Salopian Fournal.

"SIR,

"Having lately heard it asserted, as the general opinion, that the defeat of my celebrated horse, Longwaist, may be attributed to the dishonesty of his rider, I feel called upon, as his owner, to express my most firm and unshaken confidence in his integrity, till now unimpeached, and, in truth, unimpeachable.

"Nothing but anxiety to rescue the fame and character of a highly-valued servant and deservedly. admired rider, would induce me to trespass on your valuable columns; but feeling that the character of Whitehouse is as unspotted and as valuable to himself as that of the highest of our nobles is to him. I cannot resist making my confidence in his worth and integrity thus public.

-Who steals my purse, steals trash: 'tis something, nothing;

'Twas mine, 'tis his, and has been slave to thousands :

But he that filches from me my good name,

Robs me of that which not enriches him,

But makes me poor indeed.'

"I am, Sir,

"Your obedient servant,

"IOHN MYTTON."

"Halston."

- The following is a copy of his autograph: strongly indicative of 
As a pendant to the abcve, I may here introduce the following tickler that he wrote to the Editor of the "Old Sporting Magazine" in the spring of $18_{3} \mathrm{I}$, in answer to some observations that had been made about Mr. Beardsworth and the horse Birmingham.

\section{"GUY STAKES AT WARWICK.}

"SiR,

"If there is one thing more absolutely requisite than another in a letter which is istended for the public eye, it is accuracy; or, to speak more plainly, Truth-a qualification that your Correspondent, ThE Young Forester, has in your Magazine of this month (February) unhappily overlooked.

"In page 247 he says, 'The stake at Warwick has been awarded to the owner of Cetus, who was second, in consequence of the present owner of Birmingham having refused to pay some paltry $25 \%$. for-

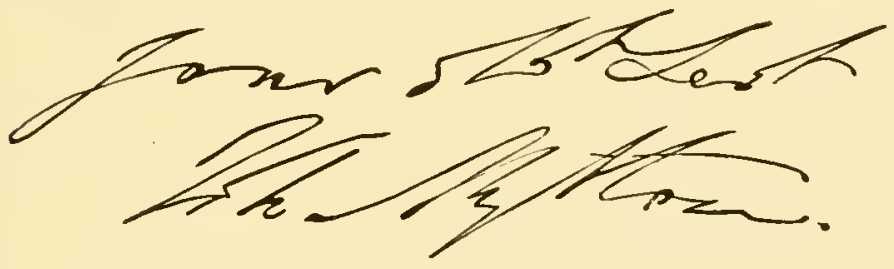


feit for a stake at Winchester, where the horse was engaged in the name of the person whom Mr. Beardsworth bought him of.'-This is notoriously untrue; and, by the manner in which the writer speaks of the transaction altogether, it is to be feared it is wilfully so.

"The next paragraph I apprehend, too, is incorrect; but which I will not speak so positively about, because I know but little of racing, and therefore am unwilling to compete with so precocious a youth as this appears to be.

"He says, "It has long been one of the best acknowledged rules of racing, that no horse is entitled to be a voinner until all the arrears due for such animal have been paid up.' Is he sure of that? Where is the rule to be found? Has he not made a mistake? and instead of the words 'to be a winner,' should he not have said 'to start?' This talented gentleman may not see the difference. Great wits, they say, have short memories-perhaps they are short-sighted too! In my humble judgment, there is a great deal of difference. By making use of the word 'start,' you afford the owner an opportunity of paying the stake in arrears, if applicd for, instead of letting the onus hang over his head till he has clefeated his antagonists. 
"And now I would ask, did Sir Mark Wood 'most honourably' make any application to the Stewards or Clerk of the Course before Birmingham started at Warwick for the paltry $25 l$. forfeit at Winchester? The Young Forester answers this question partly, asserting, 'he apprised both trainer and master, previously to the race, of the objection he had to make. Now if he had done so, I should say they (that is, the trainer and master) were not the proper persons to apprise. The Stewards (or at all events the Clerk of the Course) were the proper persons; but, unfortunately for the The Young Forester's veracity, here is another untruth: Sir Mark Wood did not 'most honourably' apprise Mr. Beardsworth (the owner), previously to the race, of the objection he had to make.

"'Save me from my friends,' he says, 'has been the cry through many ages :' but instead of Mr. Beardsworth echoing it, I guess the Jockey Club and Sir Mark Wood are more likely to apply it to this doughty genius, and conjure him, if he is determined to attempt to take their part, that he will assert only that which is true.

"I am, Sir, your humble Servant,

"Halsion, Feb. 19. $1831 . "$ "John Mytton. 
Mr. Mytton and his confederate disputed the decision which gave the race to Cetus, and brought an action against the stewards for the recovery of the stakes, but in this they were again worsted.

A summary of Mr. Mytton's actual racing career may be comprised in a few words. He had too many horses in the first place, and too many of them not good enough to pay their way. It is evident he was anxious to have good ones in his stables by the prices he gave; but he bought several of that sort after thcir day was gone by: for example, Comte d'Artois, Banker, Longwaist, \&c. \&c. He had, however, several good winners, old Euphrates at their head; and Whittington, Oswestry, and Halston, were esteemed very "smart" horses in the racing world. Indeed, it is believed that in some hands they would have been trump cards. As for himself, as a racing man, he was too severe upon his horses; they rarely came out fresh, after Chester and one or two other places; and therefore, this fact admitted, he had, I think, as much success as he could have expected. He seldom backed his horses to any serious amount; generally not at all.

His stables were, as has been before stated, upon Delamere Forest, in Cheshire, and he had at different 
times for training grooms-William Dunn (also his rider, who was killed); Maurice Jones, one of the old sort; William Dilly, and Thomas Horsely: Jones had always one answer to his master's question, "Shall we win this race, Maurice?"-_Well, I can't say, indeed, sir; but $I$ think we shall be nigh handy', please God." His home stud-groom, Tinckler, was also one of the old sort, a careful nurser of young racing stock, but too fond of green meat to contend with young horses of the present day. Mr. Mytton never bred a good race-horse.

This anecdote of Maurice Jones reminds me of another. I was once on a visit to the late Mr. Bayzand, of sporting notoriety, when he received a letter, enclosing a bill of expenses for training, from "old Sadler," as he was called, father to the more generally known Isaac Sadler. It contained the following postscript: "I have had a terrible summer of it; won nothing; but, by the blcssing of God, hope to do better next year."

The stables and boxes at Halston have the doors covered with a greater or less number of "plates," as the tips worn by race-horses in running are called. They are painted light blue, with white in the centre, 
on which are printed most of the horses' names, and the stakes won by them in every year, up to the close of $1 \$ 27$. Each stake or race won has a plate to record it, and these are arranged by half dozens in a line across the breadth of the door. The career of any particular horse is given on the door of the stable or box he once occupied, and there are nine stables and box doors covered with plates in the following order :

On the door of the first set of stables are 27 plates in commemoration of as many races.

On the door of the second stable

$\begin{array}{ll}" & \text { third }, \\ " & \text { fourth } \\ " & \text { fifth } \\ " & \text { sixth }, \\ " & \text { seventh } \\ " & \text { eighth }, \\ " & \text { ninth },\end{array}$

$\begin{array}{cc}17 & " \\ 18 & " \\ 24 & " \\ 5 & " \\ 6 & " \\ 16 & " \\ 26 & \\ 26 & \end{array}$

Total $\quad \overline{165}$ races.

But there are many stakes not recorded in this way; and I was told none had been entered since the year i 827 .

The following horses, amongst others, won stakes, plates, and matches, to the number specified against their respective names, viz.- 


\begin{tabular}{|c|c|c|c|c|c|}
\hline & & & Bronght & & d 84 \\
\hline Langolee & - & . 2 & Euphrates & & . 16 \\
\hline Single-Peeper & - & . I & Flexible . & & . 6 \\
\hline Fox-Huntress & . & $\cdot \quad \mathrm{I}$ & Longwaist & & • \\
\hline Chance . & . & - I & Tattoo . & & 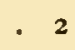 \\
\hline Sir Oliver. & - & . I & Handel . & & \\
\hline Jovial & . & - 1 & Claudius . & & . \\
\hline Milo Mare & . & . I & Paul Potter & & . \\
\hline Harriette Wils & & 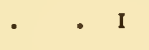 & Bowsprit . & & \\
\hline Mandeville & . & - 8 & Colt by Amadis & & . \\
\hline Ruler & . & . 2 & Oswestry . & & - \\
\hline Libertine . & - & - I & Ludford . & & - 4 \\
\hline Victorine . & - & - 2 & Geranium. & & . \\
\hline Mallet & . & . 4 & Cannon-ball Fills & & - \\
\hline Whittington & . & .14 & Louisa & & - 3 \\
\hline Alexander & - & . 2 & George the Thirc & & - I \\
\hline Habberley & . & $\cdot 13$ & Halston . & & . \\
\hline Cara Sposa & $\cdot$ & $\cdot 2$ & Sir William & & . \\
\hline Ashbourn & - & - I & Chancellor & & - \\
\hline Anti-Radical & - & .17 & Nettle & & . \\
\hline Banker & - & - 4 & Paradigm. & & . \\
\hline Ostrich & . & . 2 & Berghill & & \\
\hline Comrade. & - & . 1 & Comte d'Artois. & & . \\
\hline Colt by Bustar & & - & & & \\
\hline
\end{tabular}

Turning from his more public life as a sportsman to his domestic relations as a husband and a father, a delicate hand is certainly required when speaking of Mr. Mytton's conduct towards his two wives; for the mind naturally revolts from retracing, circumstantially, anything intimately connectea with 
the sacred compact between man and wife. But, as the reader will perceive, I should fail in my object, in writing this memoir of my departed friend, if I shrank from the arduous and painful task. I need no justification for the performance of it; I find it, first, in the fact of the notoriety given through the public journals to the proceedings in Chancery on the final separation of Mr. Mytton from that amiable lady who survived hin ; and, secondly, in numerous misrepresentations that have gone forth to the world, which, to the utmost of my ability, I shall endeavour to clear up. I wish, however, for one sip of Lethe now, and that my readers could partake with me of the same cup; for as in criminal law good character bears no weight against positive evidence, at least as regards the verdict returned, so I much fear the numerous virtues of my old friend will not here more than balance the account, unless large credit be given him on one score. The follies of mankind are familiar to our view, and we can always find an excuse for them; but it is difficult to account for that evil principle which prompts a man to give pain to a woman whom in his heart he loves, and whom he has every earthly reason to love. Sic visum est diis, "'Tis the will of the gods," said the 
ancients-a poor excuse, if not a little blasphemous; and I should rather lay it to poor human Nature, who sometimes exhibits herself in most mysterious guises, as was the case here, accompanied by errors and failings over which, as we are not permitted to command oblivion, delicacy and humanity would fain draw the veil.

But this painful part of my subject, if my end is to be attained, will not admit of concealment, and the evil must at once be laid bare to our view. I reluctantly admit, that Mr. Mytton's conduct in the marriage state is in great part indefensible, and can only be palliatcd by a due allowance, which must not be denied him, for that sort of insane delirium under which he so frequently laboured-no matter from what cause-and to which so many of his otherwise unaccountable acts-not the acts of John Mytton per se-can alone be placed. Delusion is the true character of insanity; and when I say that great part of his unjustifiable, and, by the world, I fear, hitherto unpardoned treatment of two of the most exemplary and virtuous women in existence, was jealousy, nothing more need be said to establish this point. What says the poet? and beautifully has he said it- 
"It is jealousy's peculiar nature

To swell small things to great; nay, out of nought

To conjure much; and then to lose its reason

Amid the hideous phantoms it has formed."

In the case before us, not only the groundlessness, but the unreasonableness of his suspicions, were such as could have emanated from no sound mind, which never dreams of effects unconnected with a cause; and this is nearly the sole mitigation I have to offer for one of the greatest blemishes human nature can sustain. On this point he was mad; on others, only eccentric; but as has been falsely said of wit, "thin partitions do their bounds divide." The fate of each of these ladies, however, has been a hard one. The one dropped into an early grave; the other would have been torn from him by her friends, had she not made up her mind to abandon him, lest, like Semele in Jupiter's, she might have found her death in his embraces.*

But, setting aside this monomaniasm, what further

* So tender is woman's fame, that the very breath of calumny will taint it. It behoves me then to say, that, in their situation as wives, two more correct in their conduct might have been searched for in vain, than the ladies I am now alluding to. Any man but Mr. Mytton would have been proud of exhibiting them in public, but had they lived in the days of Pericles, or even been the wives of the Great Mogul, they could scarcely have been more secluded than thes' were at Halston. 
extenuation have I to offer? I answer, as regards his second lady, none, save madness. His first and himself were not well assorted. She had been nursed on the lap of refinement and fashion, to which her betrothed was a stranger, and was, by consequence, ill calculated to be the wife of a rough country squire, who had never been at Almack's in his life, and who had something like a sovereign contempt for all such exclusive associations. Nor was this all; and should any young female's eye rest for a moment on this page, let it well observe, that it may well mark, one rock on which thousands of her sex have split, and which she to whom I am alluding did not steer clear of. The first Mrs. Mytton conducted herself with coldness to hor husband's old friends and companions, the sons of the native gentry of his neighbourhood, in every respect her equal. To a man of Mytton's temperament, to whom an old friend was "as the core of the heart, or the apple of his eye," this could not have been without its effect; and on one occasion is

Not even a race-ball would he let them be present at for some years of his life! To what motive but jealousy, or what is worse, suspicion, could such conduct be attributed? In justice to the deceased husband, however, I must state that the health of the first Mrs. Mytton was very delicate when she was married, which may account for her premature death. 
said to have drawn tears from him, during a dinnerparty at his own house: and from my knowledge of the man, I doubt not the fact.

There is a readiness to believe ill reports without examination into their truth, and we are often found guilty by those who will not trouble themselves to look into the accusation. Is all true, then, that has been reported, and credited by too many, of $\mathrm{Mr}$. Mytton's conduct to his first wife? Certainly not. Fame loves to double, and the world is not only credulous, but loud, and too often scurrilous, in its censure. Not content with the varinus embellishments of vulgar rumour, absolute falsehoods were in general circulation; and amongst them the following:- $\mathrm{He}$ was accused of having thrown her lap-dog-curse those lap-dogs! married women have no business with such pests-upon the fire; but, fortunately for the memory of my departed friend, the act that gave rise to the vile report I myself was a witness to. He merely took it up in his arms, threw it halfway up to the drawing-room ceiling, and caught it, without injury, on its descent. The butler (who happened to be in the room at the time) called out, "O Mr. Mytton! you'll kill the dog!" and the lady screamed and cried; and on this was the dreadful charge founded. In the 
hilarity of high animal spirits, Mytton was much given to practical jokes, as all his friends know. Thus, on the same lady once accompanying him to the kennel, he shut the door upon her for an instant, after he himself had got outside of it, and this was magnified into his wishing, or, I believe, intending, that she might be devoured by his fox-hounds. Again, he threw her into deep water! Nonsense; he was never mad enough to do that. He merely, one very hot day, pushed her into the shallow of his lake at Halston, a little over her shoes. All this was, no doubt, wrong by a young lady who had been brought up so tenderly as Miss Jones had been reared, but with a hundred young ladies I could name, who had been differently treated in their childhood, nothing would have been thought of it beyond a joke. And then we should look at the man. If, independently of his own immediate connections, he had a greater regard for one person than for any other, I have reason to believe it was for his Halston chaplain, and he was two or three times nearly being the death of him-once absolutely confining him to his bed for several weeks, from the consequences of his having, by way of a "lark," knocked him over some iron railing at his hall-door at Halston. Cruelty 
was not the property-no, not even the excrescence -of his nature; although, in his practical jokes, I admit he was rough, judging perhaps of other people's corporeal feelings by his own.*

I have said he was without excuse for ill-conduct to his second wife, and must agrain say, why? Not merely was her beauty the weakest of her charms, and her disposition and temper most amiable, but all who knew lrer will join with me in saying, that if a wife had been selected for Mr. Mytton with a view of reclaiming him, and making him a domestic character and a kind husband, she might have been the woman fixed upon for the experiment. Like Terence's lover, then, he should not only have sworn never to have forsaken, or unkindly treated her, forasmuch as she was the object of his choice, and had been with diffculty obtained; but there was that suitableness of temper (the "convenizut mores" of the poet), which the one valued so highly, and the other had not, perhaps, met with before. In short, there was every

- How many times have I overheard such remarks as the following made on Mr. Mytton, by ladies, in my hearing, in distant parts of England, and, indeed, now and then nearer home. "Oh, he is a brute! he threw his wife's $\operatorname{dog}$ on the fire, and burnt it alive. He tried to drown her, and wanted his hounds to eat her alive." Pshaw ! 
prospect of happiness from this union, and for some years iudeed it appeared to be realised; but whether it was that he once again nursed a vulture to feed on his own heart, or whether it was not in his nature to live comfortably for any length of time with a woman, however suited to his taste, and however dear to his heart, is a question not to be resolved by man. He has, certainly, been exhibited as a pattern of ruffianism in his conduct towards this amiable lady; and as some detail of it has already been before the public, a repetition would be useless, as well as painful to the humanity of my readers. But here comes the paradox. He loved this woman to distraction; he would have given the apple of his eye for her at any time; he would have risked twenty lives to have gotten her back again, and obtained her forgiveness; he raved about her in his madness; and sent her his dying benediction! Were those brutal deeds, then, the deeds of the kind-hearted John Mytton-kind to every living soul but the woman whom he loved to distraction? Oh, no; they were the deeds of a man visited by the hand of the Almighty, afflicted with a distempered brain, a monomaniac beyond all doubt. Could he then, like Sylla, have got an act of oblivion passed in his favour for this sad stain on his other- 
wise good name, he would perhaps have passed even an earthly tribunal. But how fortunate is it, $\mathrm{O}$ man, and especially for you who may be the loudest to condemn him, that we have reason to hope there is more mercy in heaven than in this often too reproachful world.

But is it possible, it will still be asked, that $\mathrm{Mr}$. Mytton could have really loved either, or both of his amiable wives? Indeed, reader, he did, and, woman-like, despite of his conduct, they both loved him. Neither did they reproach him. He could not complain with the noble bard-

"Though my many faults defac'd me,

Could no other arm be found,

Than the one which once embrac'd me,

To inflict a cureless wound?"

But he might have joined his brother exile in his plaintive song-

"Alt my faults, perhaps, thou knowest ;

All my madness, none can know ;

All my hopes, where'er thou goest,

Whither, yet with thee they go."

And I speak from experience on these points. In the fatal illness of his first wife, I obeyed the call of friendship, and went to him at Clifton Hot Wells, where she died, and I can vouch for his sufferings on that occasion. Who that has ever seen him look 
upon her portrait at Halston, and speak of her afterwards, could doubt the truth of what I have asserted? And yet, could they both rise from their graves, and were he to meet her again in all her beauty, and with all her charms, as he had net her before on their bridal day, I would not answer for many years of domestic happiness, even with the experience of the past to boot. "What is passion," says my Uncle Toby, "but a wild beast?" and unless restrained by reason, or subdued by temperance, it is as furious and violent as the brute beast himself. We may throw a gem to a cock or a pearl to a swine, but each would be better pleased with much humbler fare sought for and selected to their wild taste and pleasure; and I need not apply the moral here. It has been shown beyond a doubt, that it was not in the power of woman-no, nor in the power of himself-to have made John Mytton a good husband; indeed he ought not to have entered into the marriage state at all.

We must, then, still proceed in the catechetical mood. How could any woman venture on Mr. Mytton as a husband after the publicity given to the history of his proceedings towards his first wife? I answer, In the first place, many of the evil reports in 
circulation were found to be untrue. Secondly, there was a great intimacy, as well as congeniality; if I may apply the word here, between the brothers of his second lady and himself, who could see nothing but what was congenial in their brother-sportsman and friend. Again, Why was Venus (the Egyptian one) represented standing naked on a lion, but to indicate that love conquers even the fiercest beast? Here, then, was the lion in toils. The suing lover was on his very best behaviour during the days of probation, to which I was myself a witness, for he often made my house his home, as it was within two miles of that of the object of his choice. Again, "Credula res amor cst,"-Love believes everything; and not only the young lady-and young she was, for, if my memory serves me, she was only in her seventeenth year-but we all believed there was a fair prospect of happiness in the anticipated union. Neither was it suffered to take place without due consideration. The pros and the cons were nicely weighed and weighed again by the anxious mother, and they appeared nearly to balance the scales. Still it was long before her mind was made up, and in the intimacy of our friendship she put the following home question to me:- "Had you a daughter marriagreable," said this amiable lady, and 
exemplary pattern of a wife and mother," "would you like to see her married to Mr. Mytton?" I very well remember my answer, which was this: "In my cpinion, Lady Charlotte, Mr. Mytton has no business with a wife at all; but should he marry your daughter Caroline, there is a greater prospect of his making a good husband to her than to any other woman in the whole world." Now, not only did my words prove true, but for several years he was a good husband, and had it not been for "the grave of reason" which excess of wine became to him, as indeed it does to most other men, I doubt not he would have continued in the same course. But what an exemplary wife did Miss Caroline Giffard become to him! How well did she bear her seclusion from society; what allowance did she make for his libertine life; how much did it cost her to estrange her heart from him who had stamped it with its first impression! "I cannot help loving him, with all his faults," said she to me, one evening at Halston, after recounting some of his acts, which only a madman would have committed; and were my life to endure a thousand years, I could never lose my recol-

- Lady Charlotte Giffard, a daughter of the house of Devon. 
lection, unless I lost my reason, of that distressing scene. But it is true, thought I, as I listened to the sad tale, what is said of woman, that Heaven is pleased to make distress become her, and dresses her most amiably in tears.

But independently of conduct towards herself, there were other circumstances which must have been the source of much pain to this amiable lady. Nothing is more precious to a woman's heart than the good name and credit of him she loves. The unfortunate turf connection, then, between Mr. Mytton and the person I have just previously alluded to, sank deep in that of the lady in question, and well might it have stung her honest pride to the quick. The best of men is not free from human infirmity; but of all the vices short of what is termed "the great offence," to which a gentleman can be addicted, nothing so far debases and lowers him in the eyes of all who have an interest in his welfare, as his quitting the rank to which he by birth belongs. 'Tis the last step to a general dereliction of all gentlemanlike feelings, and a sorry compliment to his former friends. "Tell me with whom you associate," said the sage, "and I'll tell you what you are," was one of the noblest lessons, if not the severest rebuke, ever given to 
mankind. It is the voice of custom echoed by the voice of reason.

I have but little to say of Mr. Mytton as a father, but that little is in his favour. He was very fond of his children, although, as may be expected, he had a peculiar way of showing his affection for them; such as tossing them in the air as he did the lap-dog, giving view-holloas in their ears at a very tender age, throwing oranges at their heads, and indulging in all such practical jokes; but as the brute said of the eels he was skinning, it was "nothing when they were used to it," and I think his conduct towards them was nearly sans reprocke. He often spoke of them in his exile; and when he came in contact with other persons' children about the age of his own, a close observer would detect the workings of a strong inward feeling which it was not in his power to conceal. But why should he wish to conceal it? There is a chord in the breast of a savage that responds to the voice of nature! John Mytton himself could alone answer this question; but as a celebrated character in antiquity wished for a window in his breast that every one might see into it, a peep into that of this man would have exhibited qualities and virtues which not only the world refused to give him credit for, 
but which he himself seemed resolved it should not believe he possessed. Strange and unfathomable man! Hypocrisy is the homage which vice pays to virtue; God knows you paid her nothing in that coin; you seemed determined to make us think you kept no account with her at all! 


\section{P A R T I I T.}

CHARACTER, it is said, may be best illustrated by anecdote, and no man's career ever afforded a greater clue in this way than that of John Mytton. As his Memoirs have passed through succeeding editions, further material has offered itself with which it is here proposed to deal, having always in view the primary intention of the work. The best of these stories are fortunately; as it will be seen, to be gathered up about home.

On one occasion, on his returning from hunting, and when within a couple of miles of Halston, Mr. Mytton laid a trifling wager with one of the party who accompanied him, that he would reach home the first. He suffered his friend to take the lead until they arrived on the Halston domain, and were going at speed in a line with the lake, which is one of considerable breadth; when, suddenly pulling up his 
horse, and forcing him into the water, he landed in safety on the other side. Thus, by cutting off an acute angle, he gained a considerable advantage over his competitor; and, jumping the sunken fence into the flower-garden, arrived first at his hall-door. It must be remembered that he could not swim, even across a duck-pond!

It has been already shown how regardless lír. Mytton was of weather, whether hot or cold; and with the thermometer at zero, he would be seen walking to his stables before breakfast, with nothing on his person but his shirt, dressing-gown, and slippers. On one occasion he mounted a hunter in this partial attire, and, accompanied by one of his guests, equally wild as himself, rocke bare-backed over the country for three or four miles. Then, he once took Staples, Sir Bellingham Graham's man, who was fresh to "those parts," for a look at the country, on the day before hunting. Mytton on Milo showed the way, and Staples on the Hit-or-Miss mare followed, over some miles of stiff country, and with the Perry in their line. The stranger did very well until they came to a particularly green meadow, when Mytton drove on to his companion and landed him in a bog, from which he with much difficulty extricated him- 
self. In some of these frolics, however, he ascertained the good properties of his horses, which, perhaps, he would not otherwise have been acquainted with. For example, at the end of a capital run, in Shropshire, his whipper-in rode a horse called Oliver, over a brook which Mytton's own horse refused. "Stop!" said he to him; "it is fit that the master. should ride the best horse;" and from that day till the horse became blind, which was not for severall seasons afterwards, no person but himself rode Oliver with hounds.

Frolics of all sorts delighted him. On one occasion a thought struck him that a good race might be made between waggon-horses; and seeing four of his own at the moment, he ordered all their gearing, except their bridles, to be taken off. He then mounted one of them, and persuaded three of his friends to jockey the others, and away they went! By a preconcerted plan, however, Mytton placed the waggoner at a spot where the ground was somewhat on the descent, with orders to cry out "Who-ho!" at a signal to be given by himself. The word was given accordingly, when the horses, knowing the voice, and glad to obey the word, stopped so suddenly as to occasion two of his three friends, who rode on the 
bare back, to roll from their seats, and fall headlong to the ground.

In a long frost, Mytton was often at a loss for out of-door sport, although he was far from being particular as to the means by which it could be procured; so little so, indeed, that I remember his once letting out a fox, and a lot of his own hounds to hunt him, when we was aware that no horseman, not even himself, had a chance to follow them over two fields, and consequently they were seen no more till the next morning. Being, however, during one very hard frost, quite at a loss for a lark, he sent to Oswestry for twenty pairs of skates, which he distributed among his servants, stable lads and others, most of whom, as may be supposed, were quite new to this work. He then had a number of rats turned down on the ice before terriers, one of each at a time, when tumbling was the order of the day. But a circumstance occurred which put a stop to the diversion, if such it could be called; and I only wonder that the person who was the cause of it escaped with whole bones. The purveyor of the rats was the cowman, who was paid by the tails for his rats on all other occasions, and to ensure payment for these, had actually cut off their tails before turning them down! Mytton accidently dis- 
covered this by seeing blood upon the ice, and had not the old cowman been a favourite servant, he would have had to pay dearly for his cruelty.

I have already stated that there was a heronry at Halston, in which there were annually from fifty to eighty nests. Mytton expressed a wish to have some of the young herons taken, in order to satisfy himself of the asserted superiority of heron over rook-pie. The nests being on the very tops of high trees, neither his keepers, nor any other person about the house, would undertake to get them. "Here goes then!" said Mytton; and stripping off his coat and waistcoat, he ascended a tree of prodigious height, and safely brought down his prize.

Whilst in the Seventh Hussars, and quartered with the army of occupation in France, he heard of a badger that no dog in that country was able to draw. Having offered a bet, which was accepted, that he would produce a dog in a certain given time that would perform the feat, he at once ordered his favourite servant ("old John," as he always called him, and who was in his service from his boyhood) to go to a village called Cockshut, in Shropshire, and bring back with lim one Burroughs's dog. Nor did the order end here. "If Burroughs won't sell his dog," said 
Mytton, "bring him over dog and all, at his own price!" The dog, howcver, was bought for eight pounds, and drew the badger in great style. He was a small animal, half bull half terrier; and having been brought back to England by Mytton, remained at Halston, where he was well taken care of till he died.

Many of his frolics were of a ludicrous, at the same time, of a perfectly harmless nature. On going into the bar of the Lion Inn, Shrewsbury, one evening, when somewhat "sprung" by wine, he was told there was a box in the coach-office for him which contained two brace of foxes. He ordered this to be brought to him; when taking up the poker, he knocked off the lid, and out came the foxes, to the great fright of the landlady and some of her female friends. Mytton gave them a holloa as they " broke," but they smashed such a lot of glass and crockery-ware, that the joke must have been an expensive one.

After a blank day with Sir Edward Smythe's hounds, which then hunted the Shrewsbury country, the Squire determined upon a lark when he got home. He accordingly ordered some draft hounds, which he had in his kennel at Halston, together with all the terriers and bull-dogs about the house, to be taken to 
a certain spot, where he also ordered to be assembled all the servants of his establishment mounted on whatever they could catch, down to ponies, donkeys, or mules. A fox was then turned out, and the scene was, as might be imagined, a ludicrous one, although signalised by an act of unintentional cruelty. A stable boy, on a fast pony, happening to be first up when the fox was laid hold of by the hounds, cut off his brush * instanter, when the animal, in his struggles, got out of the lad's grasp, and went some distance before he was again run into. But Mr Mytton was often in the habit of mounting his servants with his hounds, chiefly for the sake of witnessing the falls they got, from their want of skill in horsemanship.

On Crouch the trainer once making a call at Halston, the Squire took him out shooting on the plea of killing him some game. They presently came to a brook, through which Mr. Mytton as usual waded, bidding the other follow him. But

- The famous Jack Shirley purposely once did the same thing when out with the pack of a noble lord, who was not his master. He took the fox from the hounds, when alone with them, and having cut off and pocketed his brush, threw him over a thick hedge. On the huntsman coming up, Shirley particularly requested to have the brush if they should kill him ; and on the hounds again running into their fox, great was the astonishment of the "field" to find that he had none ! 
Crouch, who had filled out from a jockey boy into a round little tub of a man, naturally hesitated-he had no change of clothes with him, would be out of his depth, and so on. "Jump up, then!" said Mytton, "and I'll carry you over;" and with great reluctance Crouch at last did jump up. But, alas! the Squire only performed half his promise, for on getting into the middle of the stream he pitched the little man clean over his head into it! And he was equally fond of creating amusement, even at the expense of his own person. For example: During his successful contest for the borough of Shrewsbury, in 1819 , he threw himself from the car in which he was being "Chaired" home from the hustings, through a window, into the Lion Inn, at the imminent hazard of his life. But the turmoil of a contested election was a fine field for John Mytton. On one occasion the principal champion of the opposing party stood opposite to his inn, challenging any man to contend with him. Mytton listened to his bravado for a while, till his Welsh blood being excited, he set to, and thrashed the fellow to his heart's content in five rounds. He then put something into the beaten man's fist, as he said, "to make him comfortable for the evening." 
Mytton was very much beloved by the labouring classes within a large circle round his house, and he would enter their cottages without invitation or ceremony. His horse having fallen with him one day, and broken his knees very badly, he applied to an old woman by the road-side for some linen bandages; but being unable to furnish anything of the kind, he thus addressed her: "Never mind, my good woman ; bring your scissors here, and cut off the tail of my shirt, and then you may cut up the sleeves of it, which will make capital bandages." On another occasion, after having been long exposed to cold on the Hawkestone hills, with hounds, he entered a house near Wem, taking his favourite hunter, Baronet, along with him; and having ordered a good fire to be made to warm himself and his horse, started for home again, saying they were both all the better for it. He was by no means particular as to what he helped himself or his horse on these occasions; and is said once to have seriously injured a horse by dosing him as he dosed himself-with wine; * while he started a fashion

- It is stated by a correspondent that the horse I allude to, called Sportsman, dropped down dead in his gig, in consequence of his owner having given him a bottle of mulled port wine at Wrexham. I knew the horse well, but cannot vouch for the cause of his death. 
since more generally adopted in some parts, of treating his hunters to a quart or two of warm beer.

Again; he once rode at the Ellesmere canal, and of course got a ducking. Finding himself very cold on the road home, he exchanged his wet coat for a flannel petticoat which he espied on a cottager's garclen hedge; and slipping it over his head, travelled on with his hounds, to the great amusement of the villagers he encountered by the way.

In speaking of Mr. Mytton as a horseman, I have stated the singular fact of his never having so completely tired his horses in the field as to have been obliged to walk home, which I in great part attribute to his strength of hand in assisting them in their work. It is true he rode none but good ones; but he really appeared to have a sort of magic influence over their tempers-at all events, it seemed as if they sympathised with him in his frolics-for they were always tranquil under him, and would do almost anything he required of them. He would ride them up the hall steps and down the steps, and through the house, without their appearing to be in the least disconcerted or alarmed. The Lord Waterford doings in this way had long been anticipated by John Mytton, who would often ride round his billiard 
table: and one night after dinner rode a black pony up stairs into his chaplain's bedroom. But the pony refused to come down again, and so passed the night in his reverence's quariers.

Mytton may be said to have lived in a storm, for a row was his delight. Nevertheless, although there was an apparent ferocity of temper about him at times, it was blended with much kindness of heart, and he scarcely ever thrashed a man that he did not give him something afterwards as amends. I remember hearing of an unfortunate horsebreaker having been carried, nolens volens, by a half-broken colt into the midst of his hounds. Mytton flogged him severely, and then gave him a guinea. A baker, for much the same offence, received much the same treatment, and had his basket of bread thrown amongst the hounds, but this of course was eventually well paid for. He would not, however, suffer any man to take an improper liberty with him, and, in that case, there was no compensation for a thrashing. A Shrewsbury tradesman, when a little "sprung," ventured to call him "Johnny." Mytton floored him on the spot.

He was the dread of the owners of the minor gambling-tables who frequent country races, for he was 
given to break their banks in more ways than one. I have said, he was often a great winner; but he would demolish the entire apparatus if he suspected any unfair advantage to be taken of himself, or of any other person in the room. At Warwick races, in I 824 , he and his companions not only broke a rougeet-noir table to atoms, but gave the proprietor of it and his gang a sound drubbing into the bargain. $\mathrm{He}$ was once, together with some others, surprised by the Mayor of Chester, in the act of playing hazard, in a room hired for that purpose, on the Sunday evening previous to the races; but on seeing his Worship enter he put his winnings into his hat, the hat on to his head, and then walked away unnoticed, being taken only for a spectator. He was losing heavily one night at Chester, when he turned very faint. "Take him away," said somebody, "he's too drunk to play." "No, no," answered a friend at his side; "wash his mouth out and give him another chance." They did so, when he not only won all his money back, but a good stake to boot.

I have spoken of Mytton as a shot, and I believe no sportsman need be superior to what he was at one time of his life. For myself, I only knew him as a game shot, as the term is, never having seen him with 



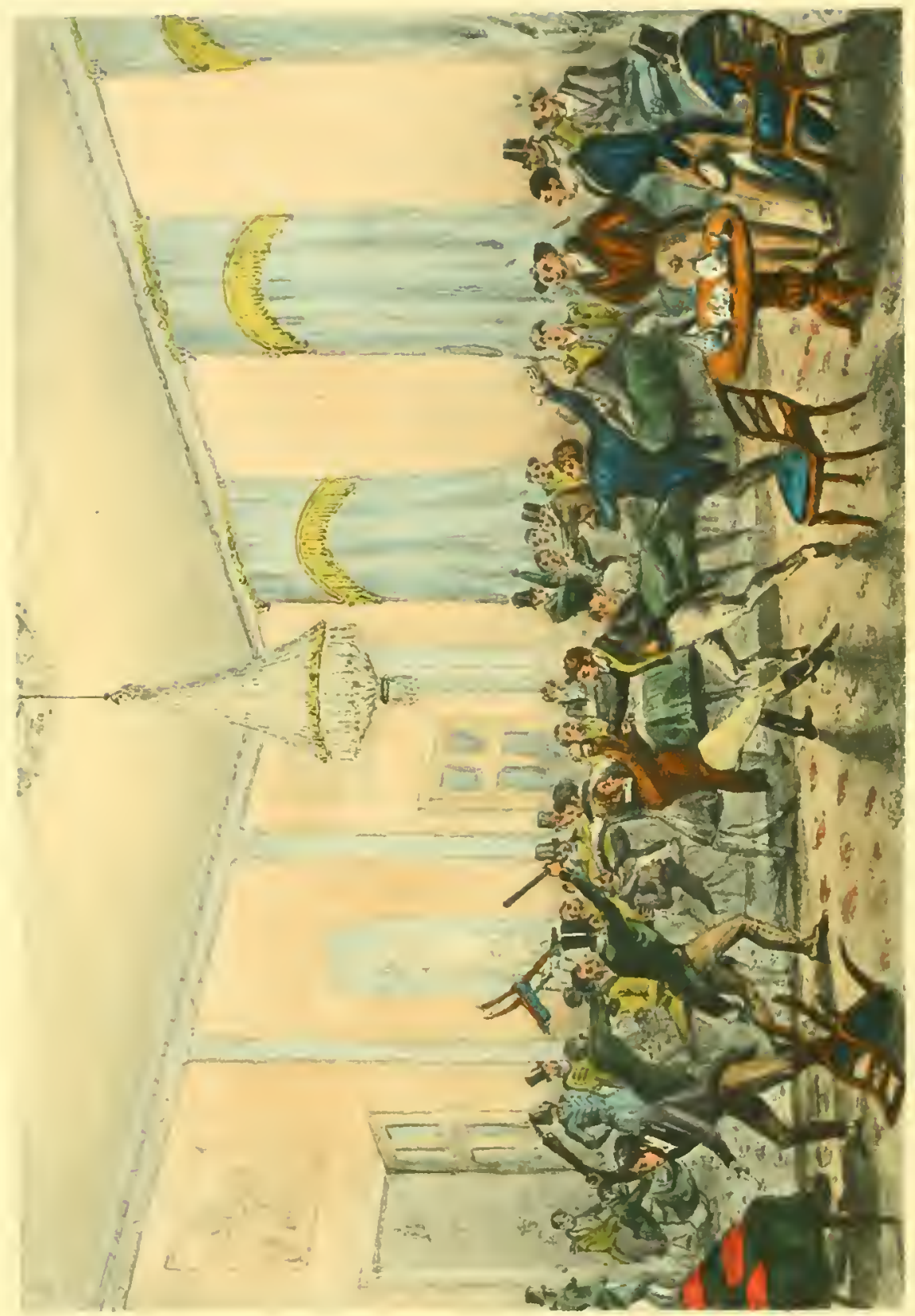




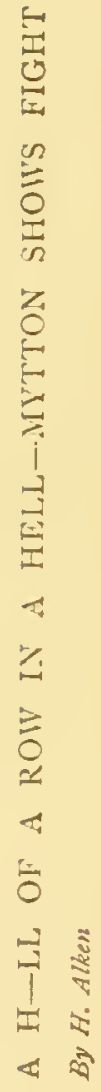



either pistol or rifle in his hand. It has, however, been represented to me that he was a most superior marksman with a rifle, so superior indeed as to be able to hit the edge of a razor at the distance of thirty yards, and occasionally to split his ball! "Credat Fudaus" - I do not add " non ego;" yet I never chanced to hear of such a wonderful performance. But I will transcribe the rest of the story, and leave my readers to make the best of it.

"He would," writes my informant, "cross the yard at Halston, and shoot from one of the iron gates on the drive, or carriage road, to the coal-house wall, a distance of fifty-five yards, and put his ball through the peg-hole of a trimmer (used for pike-fishing). The trimmer-cork, in this instance, was placed on the tame fox's cub, or kennel, with the flat side towards Mytton's aim ; and it invariably fell to the ground on each time of being fired at, the ball actually going through the aperture where the peg of the trimmer is put in, and not above an inch and a half diameter, covered with a piece of white paper, pasted thereon, to ascertain the fact! This he has done over and over again, to the amazement of all who have witnessed it, and with his rifle to his shoulder, and not on a rest, as might be imagined by some. Talk of 
Americans, for their precision in shooting, after this! It cannot be surpassed, if equalled." To this account is added the fact of his having shot rats with a rifle from the top of his house, and sundry other achievements rather too marvellous to relate.* Still he riddled the vane of his own chapel; and on one very cold morning after a very warm night, jumped into the pool merely to get a shot at some herons which he had disturbed while pheasant shooting.

But, as I have already said, no phase in Mytton's character is so interesting as that which is illustrated by his exploits in riding and driving. During the period of Sir Bellingham Graham's hunting Shropshire, he performed several gallant feats in the field. Whilst suffering severely from the effects of a fall, and with his right arm in a sling, he rode his favourite horse, Baronet, over Lord Berwick's parkpaling at Atsham, near Shrewsbury, to the astonishment of the whole field; Sir Bellingham himself exclaiming,

"Well done, Neck.or-Nothing! you are not a bad one to breed from!"

- For example, he is represented as having more than once put a ball through a man's hat whilst on his head! 



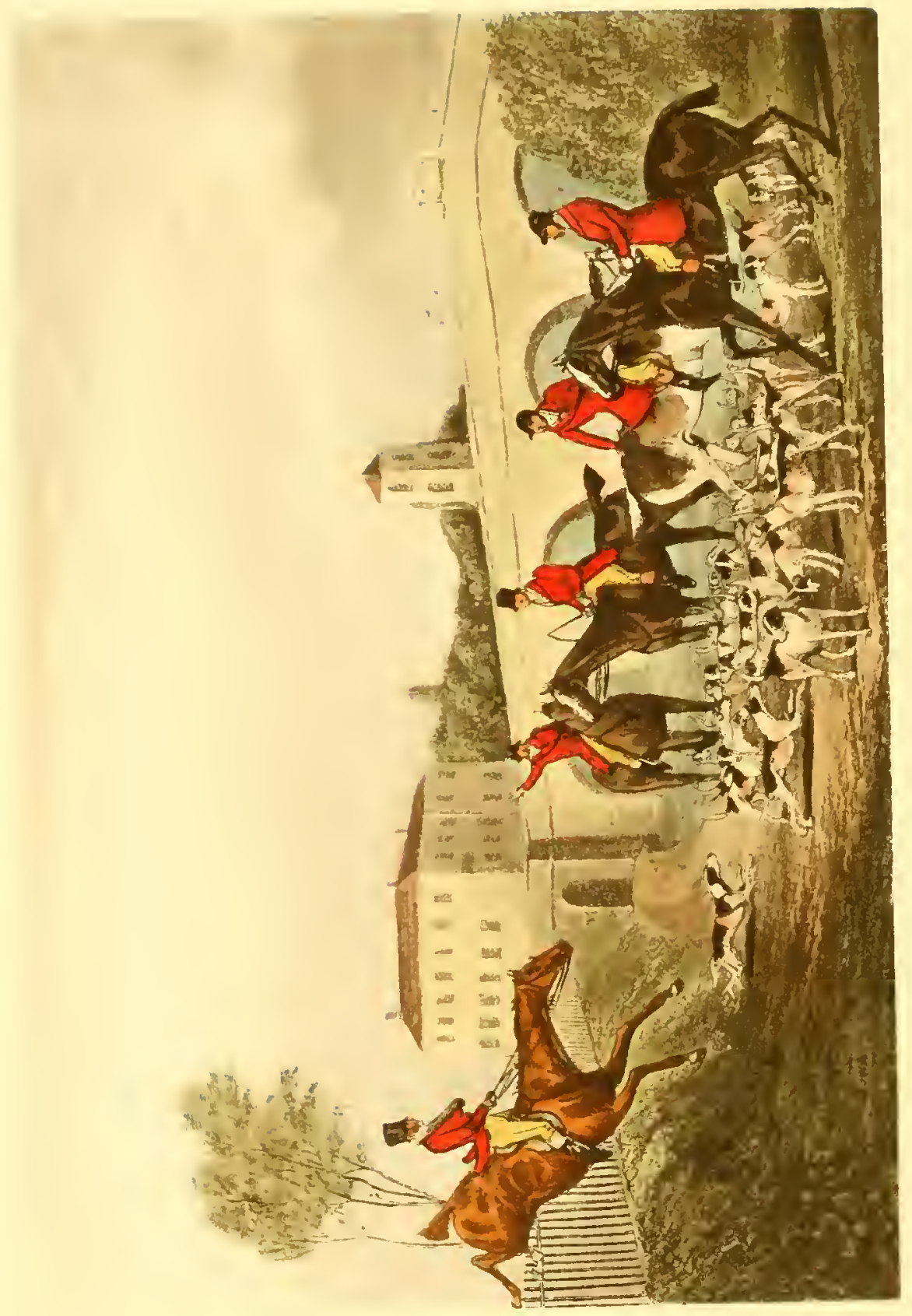




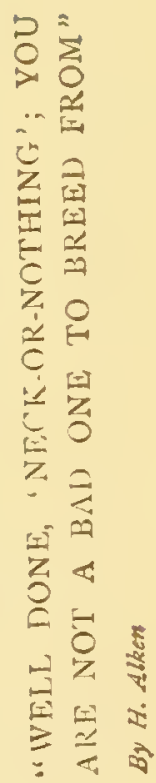



With the same hounds, he signalised himself greatly in a run from Bomer Wood to Haughmond Hill, when the river Severn brought the field to check. Three or four of them managed to get their horses into a boat, but Mytton scorned such assistance. "Let all who call themselves sportsmen," he exclaimed, "follow me!" and, dashing into the stream, gained the opposite bank, and was one of the very few who saw the fox killed. It must again be observed that Mytton was no swimmer, and the Severn is broad and deep, and the banks none of the best. Still he did not always disdain the aid of a boat, and on his own hounds once crossing the Severn at Quatford the Squire jumped into the boat alone, and quickly shoving her off landed on the opposite side and sent her adrift! The rest of the field had to go round by Bridgnorth. Then, he fell into one of the deepest parts of the same river out of a ferry-boat when luckily not alone, as he was saved by his companion catching him by one of his legs, as he was just being sucked under the boat.

On another occasion he nearly lost his life in the Severn, also in a run with his own hounds, near Bridgnorth. All the field but himself crossed it by a horse ferry-boat, but he gallantly plunged into it, notwith- 
standing that the river was much swollen by rain at the time. His mare, Cara Sposa, was carried a long way down the stream by the current, and although she at length gained the opposite side with him, the bank would not admit of her landing herself. His whipperin, Ned Evans, however, who had crossed by the boat, fortunately came to his assistance, and pulled him up the bank, leaving the mare in the water. Nor does the story end here. Jumping upon the whip's horse, Mytton got to his hounds, and the mare was eventually brought ashore without much injury.

Still I have reason to believe the hair-breadth escapes on wheels even exceeded those in the saddle, which, perhaps, may be in some measure accounted for by his early predilection for tandem-driving-the most hazardous business of any, even in the best of hands--and Mytton was no coachman.* The following feat certainly out-herods Herod; but my readers shall have it exactly as I myself had it, accompanied with the following remark-Nothing, we are led to believe, is impossible with God; nothing was improbable of the late John Mytton.

"When I say he was "no coachman," I mean he knew nothing of the science or system of driving four horses. He would, however, now and then take hold of a tcam in the Holyhend milil, and I was told that when he did, he never attempted to lark. 



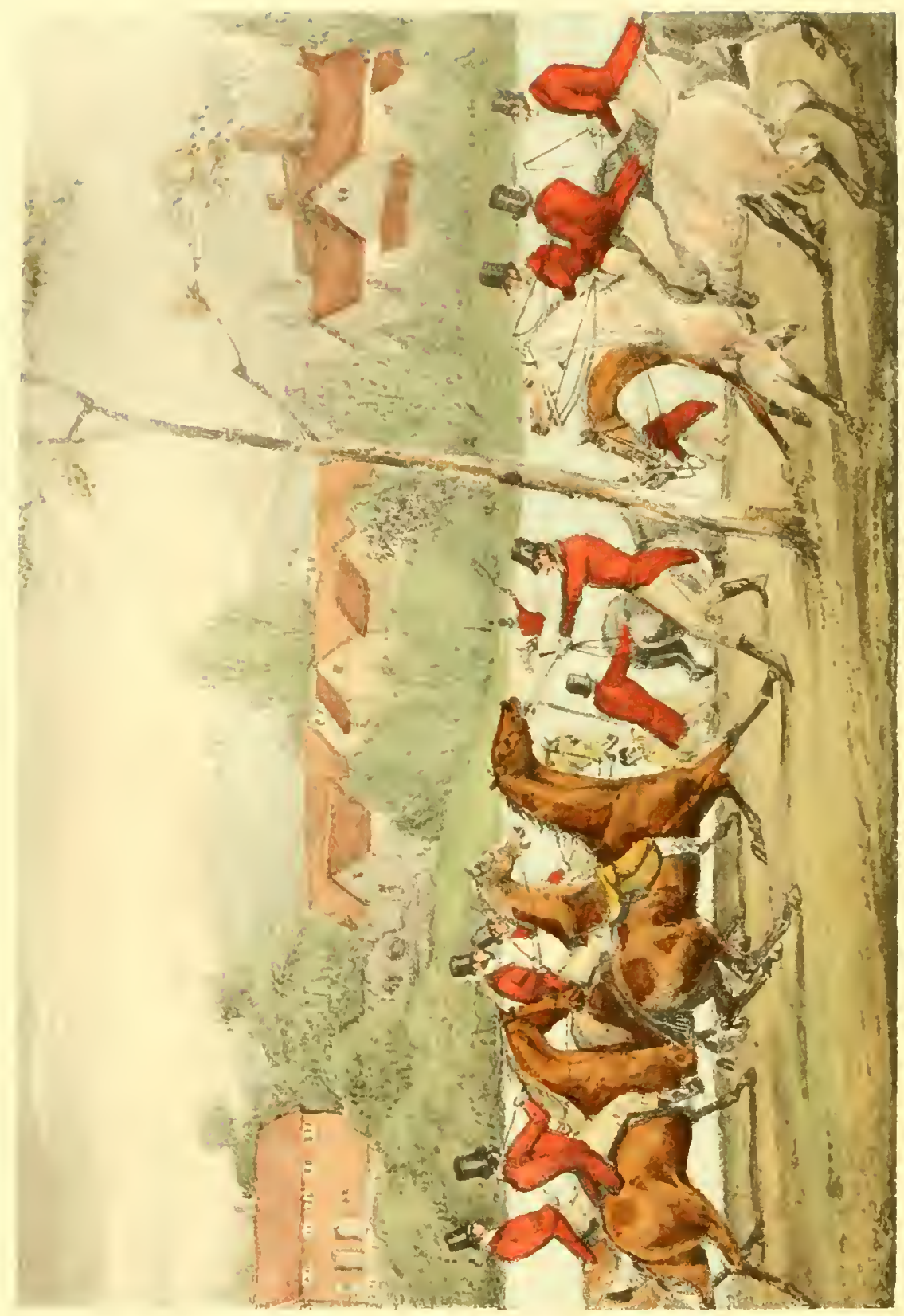




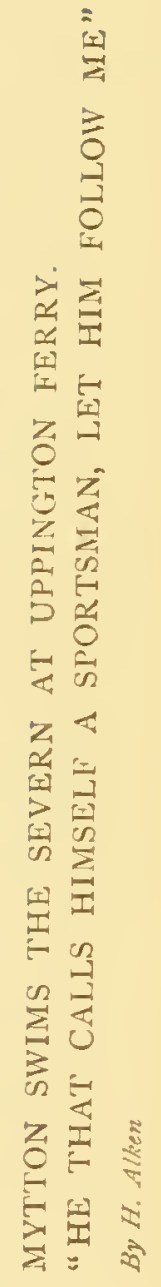


"He was one day," says my correspondent, "engaged to dine with a friend at some distance from Halston, and came, as usual, in his tandem. After dinner, the conversation turning on the danger of that mode of harnessing horses, from the little command the driver can have over the leader, Mytton at once expressed his dissent from this doctrine; and being under the influence of the 'rosy god,' offered to bet a pony (25l.) all round, that he would that night drive his tandem across the country, into the turnpike road, a distance of half a mile, having in his progress to get over a sunk fence, three yards wide; a broad deep drain; and two stiff quick-set fences, with ditches on the further side! This bet was taken by several of the party present to the tune of $150 \%$. and upwards; and after the necessary preparations, all turned out to see the fun, although in justice it should be said, as Mytton was then under age, it was not only proposed to him that the bets made should be off, but he was strongly persuaded not to make the attempt. This, however, with him had always a contrary effect; and twelve men, with lanterns on poles, having been procured, to aid the light of the moon, on the appointed signal being given, away went Mytton. 
The first obstacle was the sunk fence, into which, as may be expected, he was landed; but the opposite side being on a gradual slope, from bottom to top, the carriage and its inmate, by dint of whipping. were drawn out without receiving any injury. Nowise disconcerted, he sent his team at the next fence-the wide drain-and such was the pace he went at, that it was cleared by a yard, or more; but the jerk pitched Mytton on the wheeler's back. Crawling over the dashing-leather, he resumed his seat, and got his horses again into the proper direction, and taking the two remaining fences in gallant style, got safe into the turmpike road, and won his wager. This occurred at Mr. Walford's of Cronkhill, about four miles from Shrewsbury."

The above appears somewhat of a miraculous adventure; but that Mytton was equal to the attempt, no one who knew him as well as I knew him would doubt. Indeed I have already stated a fact (I think in my "Shropshire Tour") bearing some relation to it. He was driving me from Shrewsbury to Chillington to dinner, and after one or two trifling occurrences, such as knocking down a bullock, and breaking a shaft of the gig on the road, we found ourselves in an awkward predicament. By having 



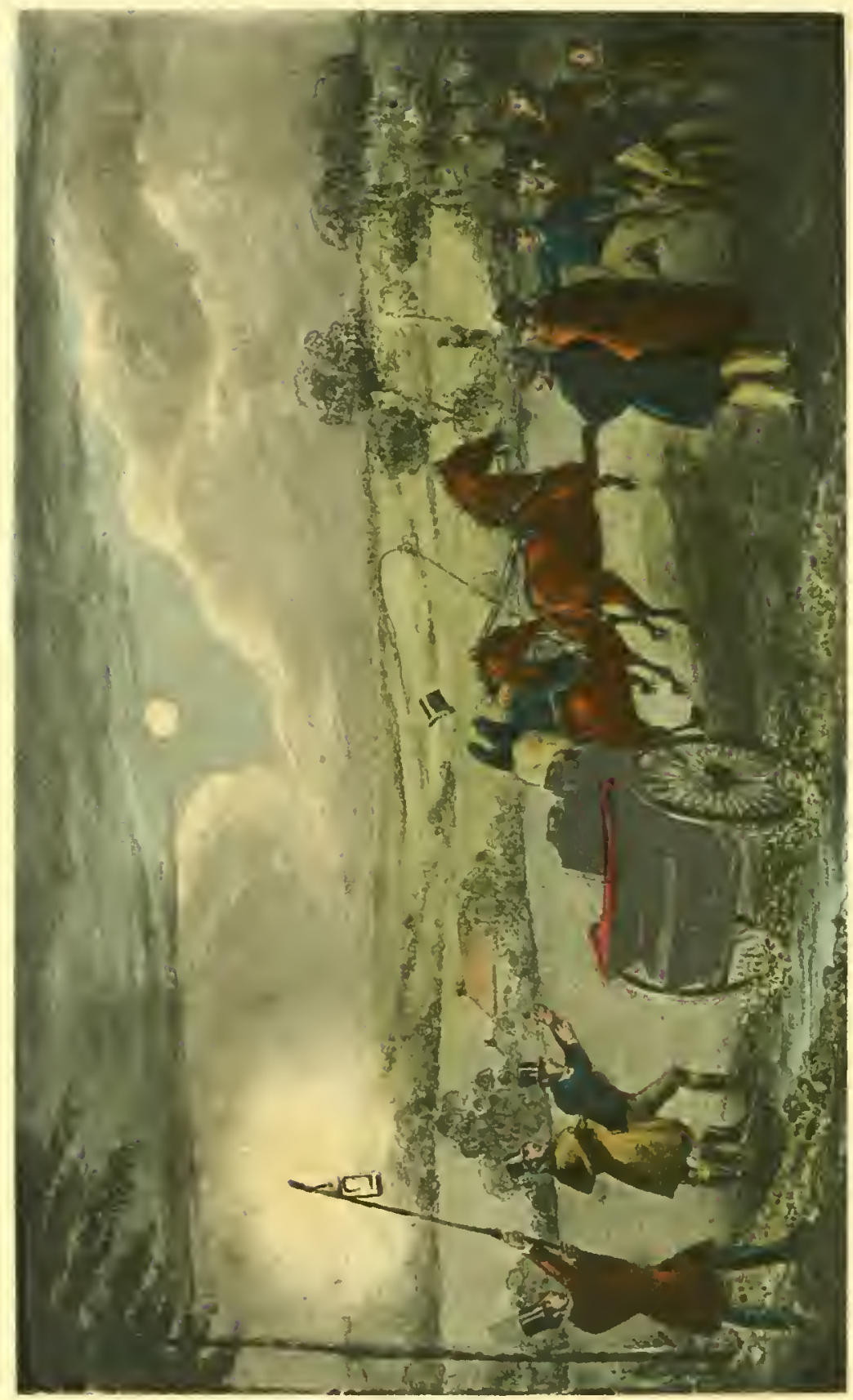




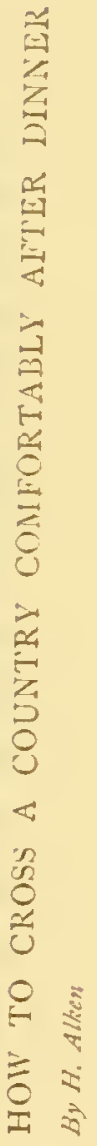



taken a wrong turn, on approaching the house, we found ourselves in a field with no means of getting out of it, except by a gate by which we had entered it; and we were already behind time for dinner. "We'll manage it," said Mytton; "this horse is a capital fencer, so do you get over the fence (a hedge and ditch) and catch him." He then merely unbuckled the bearing-rein, gave the horse a cut with his whip, and over he came, gig and all, without the slightest accident.

Having shown a friend over his stud at Halston, and also his hounds, he told him he had something still better worth his seeing in reserve for him; and on opening his coach-house doors he thus addressed him: "You see that gig. Last night it was carried clean over my lodge gate, and it is not a bit the worse for it, nor, as you have seen, is the horse that carried it over." Now this sounds rather marvellous; but the inhabitants of the town of Wrexham, in Denbighshire, can well remember a somewhat similar circumstance occurring at a villa close to that town, some twenty years back. A horse, the property of Mr. Watkin Hayman, ran away with his gig from the door, and carried it over a high palisade gate, without injury to either himself or the 
gim. I went the next day to see the gate, and the only impression left upon it was the fracture of one of the spikes, or points, of the top rail. But Mytton would wantonly seek acciclents from gigs and phactons; and latterly, I never entered into one with him, but on condition of his having nothing to do with the reins. I remember seeing him get out of his phaeton at the hall door at Halston, and instead of letting a servant drive it round to the stables, start the horses off by themselves at a gallop; and, strange to say, they conducted the carriage safely into the yard, although they had two rather sharp turns to make, and one gate to go through. This was in the lifetime of the first Mrs. Mytton, who had more than one providential escape from this same phaeton.

In his love of frolics I never knew or heard of but one person anywise his equal. This was the wellknown "Tom Leigh," as he was generally called, of High Leigh, in Cheshire,-a gentleman of very large fortune, and altogether a truly singular character. $\mathrm{He}$ had a regular pitfall in his grounds, into which he would walk a stranger who came to visit him, and sundry other manœuvres, which he called sport. Even the parson of the parish was not exempt from being made the subject of a lark, as the following 
anecdote will show. Imagining himself to be a good judge of horse-flesh, he invariably brought his new purchases to the Squire of High Leigh, partly for his approbation, and partly in proof of his own skill in the selection of them. On one occasion the nag was ordered into the stable, and his Reverence also well taken care of for the night, the next being a hunting morning. "Now, Doctor," said the Squire, as soon as breakfast was over, "we will go into the stables and see this famous new horse of yours, of which you have talked to me so much." But he was not to be found. The parson declared he himself put him in a particular stall; and there in truth he was, but the Squire having ordered him to be cropped and docked over-night, his owner had not the slightest recollection of him. As may be supposed, a hearty laugh was raised at his expense, and there was an end of all future, somewhat boring, exhibitions of inferior animals to a man who had some of the best horses that money could procure, and who was really a judge of them. But I was never an admirer of practica! jokes, especially when, as in this instance, the sufferings of an animal form a feature in them. Neither were many of the frolics of poor Mytton creditable to him. In the first place, they are always inconsistent 
with manhood; and in the next, knowing no bounds with him, they often led him into excesses which endangered his character as a man, and verified the censure passed upon them by Horace :-

\section{"Lusit amabiliter; donec jam sævus apertam In rabiem verti cœpit jocus."}

Still, some idea might have been formed of his zeal in the pursuit of every description of true sport, from the catalogue of effects sold at Halston when the establishment was broken up. The furniture of the net house, for instance, included three bush nets, 26 and 28 yards long, 5 deep; two small mesh nets for bushes; three larger mesh nets; two drag nets, with large tunnels; four trammel flue nets of various sizes; one minnow net; one minnow net and pole; three gutter nets; two casting nets; two drum nets; one cleaching net; one large salmon net; one gudgeon, or fine meshed brook net; four landing nets of various sizes; six fishing poles; four bait cans; two large fish cans; two angling chairs; two coracles, or small fishing boats; two eel spears; two trout spears; one salmon spear; fishing cases and rods of every description.

In the engine house and aviary there were six pheasant nets; three rabbit nets and several purse 
nets; two pairs of lark nets; one partridge net; various rabbit traps, in lots; one hundred and twentyeight vermin traps of every description; one badger cub; two fox cubs; thirteen dog kennels; fourteen ferret boxes; three cages for wild animals; nine birdcages; sixteen pair of quoits; two sets of bowls; sundry cricket-bats and balls.

The guns ran to six rifles of various bores; nine double-barrelled guns; four single; with some dozens of powder-flasks, shot-belts, and gun-cases; and the saddle-room would, no doubt, have told as significant a tale.

As something of a finish, for to this it was fast coming, Mytton never made himself much more conspicuous in the field than he did upon what was well known in the hunting circles of Cheshire, Shropshire, and Staffordshire, as "The Shavington Day." This was an arranged trial of speed, nose, and bottom, between the fox-hounds of Sir Harry Mainwaring, of Peover Hall, Cheshire, commonly called "the Cheshire hounds;" the pack kept jointly by Sir Edward Smythe, of Acton Burnal Park, Mr. Smythe Owen, of Cándover Hall, and Mr. Lloyd, of Aston Hall, Salop, better known as "the Shropshire hounds;" and that of Mr. Wicksted, whose kennel 
was at Betley, near Newcastle-under-Lyne, from which he hunted what is called "the Woore country" (once hunted by the late Sir Thomas Mostyn, previously to his taking Oxfordshire) and likewise a part of Shropshire. 'The interest evinced for many surrounding miles, in this extraordinary, and I believe I may add unique undertaking, was immense; and it was supposed that, independently of the contents of carriages, there were considerably more than a thousand horsemen in the field, with about seven hundred of these in scarlet.

Mytton, as usual, was resolved to make himself remarkable in more ways than one; and on the preceding evening he arrived at Whitchurch, to be near to the scene of action, and where he had ordered the best dinner that could be provicled for himself and two friends who accompanied him. But the dinner at Whitchurch and its evils were not "sufficient for the day;" he had his carriage round in the evening, and drove to the village of Wrenbury, the rendezvous of the different packs, where a main of cocks was being fought. Having seen what was going on there, he returned to his quarters at Whitchurch, and after lurawing a commercial traveller from his bed, and dosing him with wine, retired at length to his own. 
The place of meeting was Shavington Hall, the seat of that hearty old buck, that real specimen of an Irish nobleman, Viscount Kilmorey, - who, although but little of a fox-hunter himself, was a great promoter of the sport, by his strict preservation of foxes; and who left an excellent name behind him as one of "the right sort." The time fixed was eleven o'clock, and at that hour a sight highly enjoyable to sportsmen presented itself, and indeed to all descriptions of persons who witnessed it; for as is well known, there is nothing which adds more to fine scenery, in which this park abounds, than a wellattended pack of hounds at work in the covers.

The modus operandi was this:-Six couples out of each pack were selected for the trial, attended in the field by their respective huntsmen-namely, Will Head, afterwards with Lord Hastings, for the Cheshire; Will Staples, huntsman to Sir Edward Smythe, Mr. Lloyd, of Aston, and Mr. Smythe Owen, for the Shropshire; and Charles Wells, once huntsman to the Oakley, for Mr. Wicksted. Will Head acted as leading man of the day, by reason of this being in the country which his hounds claimed as their own, as well as the Cheshire being the senior pack. 
These were the best days of the Tomkinsons, the Gleggs, the Brookes, Jack Ford, and sundry other first-flight Cheshire men, so that it may be imagined that a spirit of rivalry amongst men would accompany the trial of speed in hounds, and that Mytton would be amongst the foremost to distinguish himself. That he came prepared to do so was evident by the fact of his having had the famous Hit-or-Miss mare reserved for this particular occasion, orders having been given to his groom to "have her right fit to go;" while he mounted Captain Owen, of Woodhouse, on the Devil.

Precisely at the hour of twelve the business of the day commenced; the "United" packs were thrown into what is called the Big Wood, in Shavington Park, from which a fox almost immediately broke, and, having stood before them for thirty minutes, at a very severe pace, was lost near the village of Cloverly. Mytton very soon got the lead, and very soon lost it, and nearly his life at the same time; for coming to a deep sunk fence, or ha-ha, at which there was a high and stiff rail, on the rising side, he halloed out,

"Now for the honour of Shropshire!" And gallantly charged it. This challenge, as it were, 



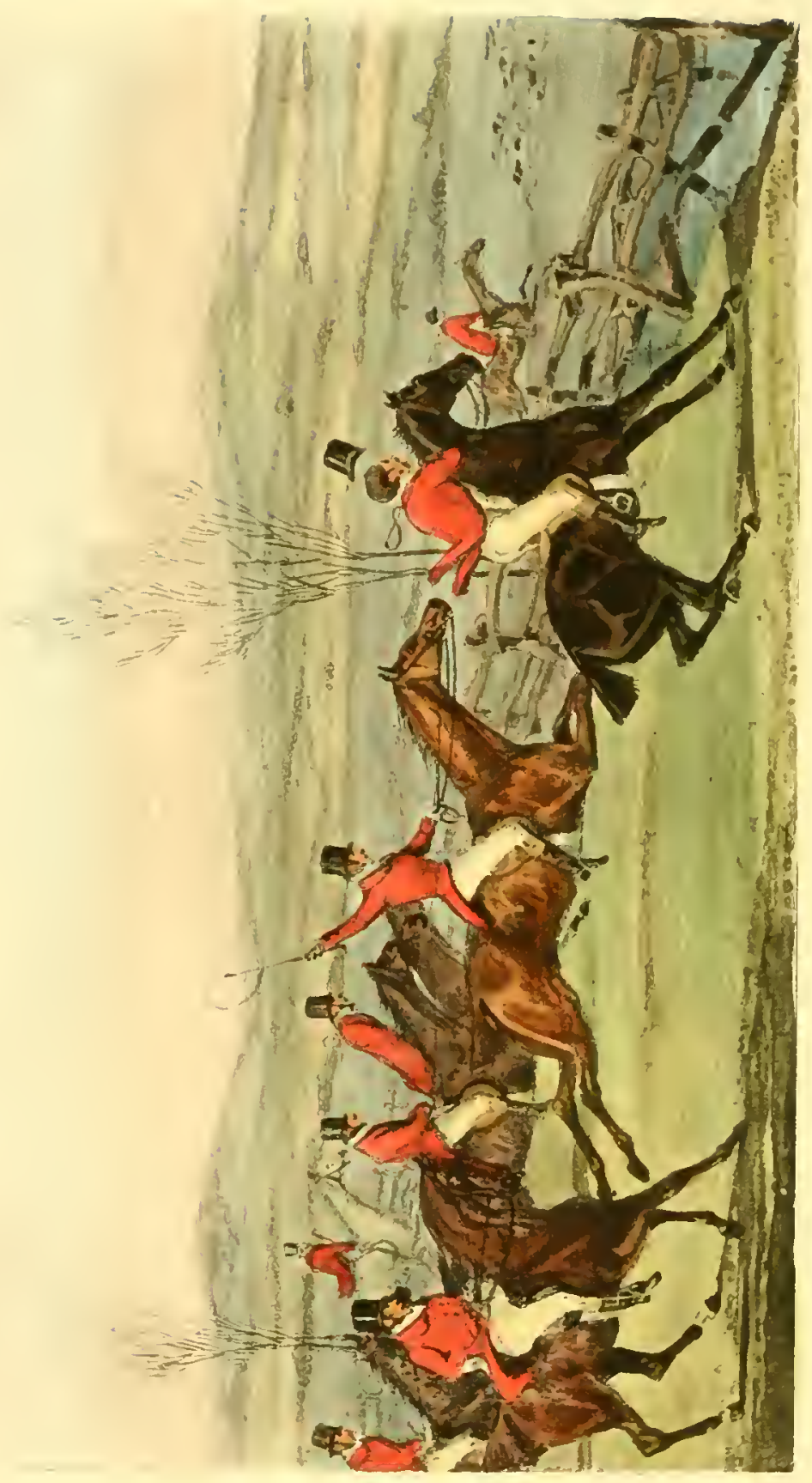




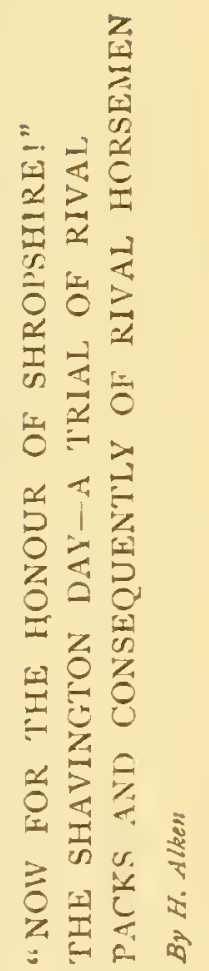


- $\div$

$= \pm$

$= \pm$

$\therefore \therefore \approx$

$=$

$-2$

$\therefore$

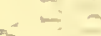

$=-$

$\therefore y$

$-2$

$\therefore=0$

x

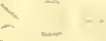

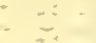

5

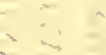

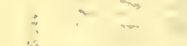

$\therefore \quad a$

$\because=5$ 
indicated two things - first, that he considered the fence something like a stopper; and, secondly, that he was determined not to be beaten by any man in the field so long as his mare could keep on her legs. But the drop, or the crowd in getting at it, proved too much for her, and she gave him a severe fall,in addition to his being much hurt by another person's horse, that had followed him, coming upon him and crushing him; there being a dozen or so down together.

The place, in fact, was a regular "Squire trap," and although Mytton quickly remounted and went on-bleeding and bare-headed, for his hat was too much crushed to be worth picking up, the horse in his wake having alighted on it-he was so much shaken by the fall as to be unable again to take his usual place, and he did little more than follow a leader during the remainder of the day. They had, however, two pretty things, a second fox being found in Lord Combermere's park, but the hounds were stopped after running for about twenty minutes, as this proved to be a vixen; and a third fox was chopped in cover. The Shropshire, with Chanter and Orator, claimed to have the best of the "hunting;" but Will Head. for the Cheshire, was always 
with his hounds, and the honours may be said to have been divided.

The Shavington Day was on the 7 th of April, I 829, when Mr. Mytton's active career as a sportsman was rapidly coming to a close. By the end of another season he was off the turf; and in the year after that had turned his back upon Halston. 



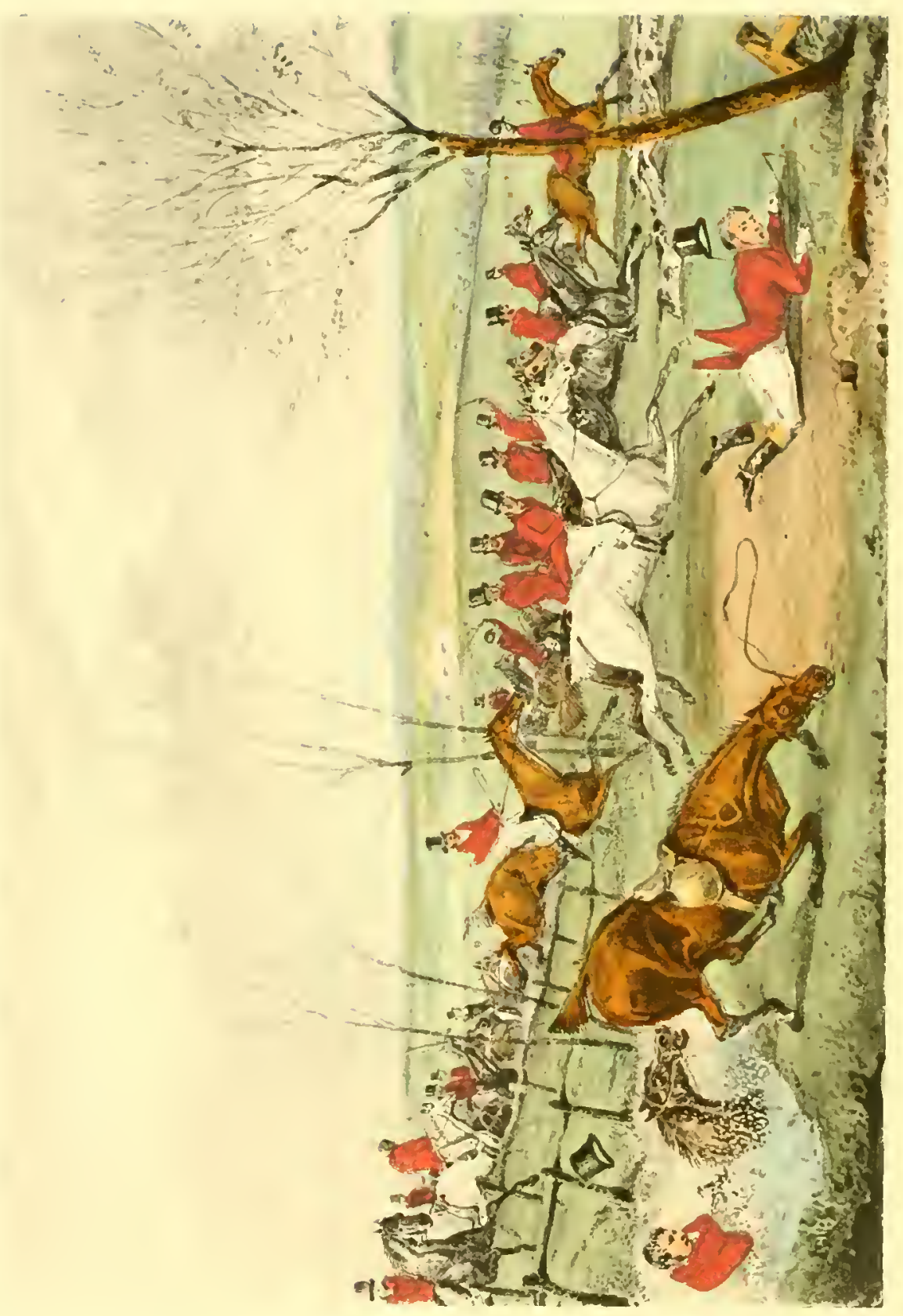




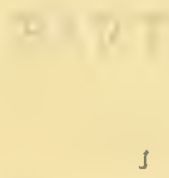

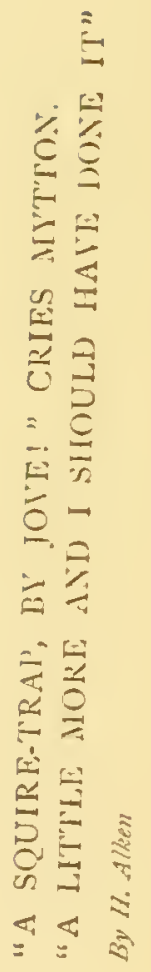




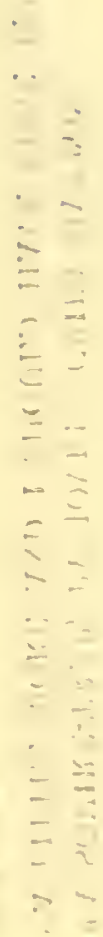




\section{PART IV.}

I HAD not seen Mr. Mytton for at least two years previously to $\mathrm{my}$ quitting England, but I had heard some unpleasant reports touching his pecuniary affairs; yet it was not until I read the advertisement in the "Times" of the sale of all his effects at Halston, that I found his race was run. As the greatness of every man's fall is measured by the height from which he fell, my heart bled as I waded through the melancholy detail of objects so familiar to my mind, so dear to himself, and also associated with brighter days of my own. "Poor fellow!" said I, to a mutual friend who was at my side. "Better he had never lived, than to have to taste those bitter moments which in future must be his portion. $\mathrm{He}$ who towered like the cedar will now be trampled upon like the bramble, and perhaps neglected by those whom his bounty once fed." What became of him, however, after the sale of his effects at Halston -for everything was sold except Euphrates, the race-horse-it is not material to inquire; and I only 
know that, being in fear of arrest by creditors, he sojourned for some time at a small hotel in Richmond," from which place are to be dated circumstances and events deeply affecting his future short but melancholy term of life.

On the $5^{\text {th }}$ of November $1 \delta_{3} 1$, during my residence in the town of Calais, I was surprised by a violent knocking at my door, and so unlike what I liad ever heard before in that quiet town, that, being at hand, I was induced to open the door myself; when, to my no little astonishment, there stood John Mytton! "In God's name," said I, "what has brought you to France?" "Why," he replied, "just what brought yourself to France; (parodying the old song) three couple of bailiffs were hard at my brush." But what did I see before me? The active, vigorous, well-shapen John Mytton, whom I had left some years back in Shropshire? Oh, no! Compared with him, 'twas the "reed shaken by the wind:" there stood before me a round-shouldered, decrepit, totter-

* Before going there, I believe he was a good deal at one of the fashionable bachelor hotels in bond Street, where he might be seen sitting down to dinner with bailiffs, money-lenders, and ragamuffins of all sorts, who haunted and followed him wherever he went. 
ing old-young man, if I may be allowed such a term, and so bloated by drink that 1 might have exclaimed with Ovid-

\section{"Accedant capiti cornua, Bacchus eris." "}

But there was a worse sight than this. There was a mind, as well as a body in ruins; the one had partaken of the injury done to the other, and it was at once apparent that all was a wreck. In fact, he was a melancholy spectacle of fallen man-of one over whom all the storms of life seemed to be engendered in one dark cloud.

After drinking some wine, he took his leave of me abruptly, saying he was going in a carriage to Guines, a small town eight miles from Calais, where he had been quartered, when in the Hussars, with the army of occupation; but, taking me affectionately by the hand, said, "I shall come to you to-morrow, for I have a great deal to say to you." The morrow came, and he himself came, accompanied by Mr. Vaughton, $\uparrow$ and I hope neither of us may have occasion to witness

" "If you had but horns on your head, you would be Bacchus."

+ A brother sportsman from Warwickshire, at this time residing in France. 
such another scene. His pecuniary affairs appeared not to give him a moment's uneasiness. As regarded them, fancy or something worse had dressed the future prospect with the gayest colours; he had seventy thousand pounds to receive, he said, after all his debts should be paid; had engaged McDonald, the jockey, to be his trainer and rider of his new stud of race-horses; and had purchased a capital house in Curzon Street, May Fair, where, of course, there were a knife and fork for me, and bail for ten thousand pounds! Neither did he appear to care twopence for what had occurred at Halston. It was to be reinstated in its former splendour, and once more was I to be his guest. It would have been cruel to have undeceived him here. Like the good citizen of Argos, he might have upbraided us for so doing, and exactly in his words :-

"Pol me occidistis, amici, Non servástis," ait, "cui sic extorta voluptas, Et demptus per vim mentis gratissimus error." •

But the sore was not yet laid bare. A very elegant writer has observed, "There are some strokes of cala-

- "It would have been better, my friends, that you should have destroyed me, than to have deprived me of the most agreeable delusion of the human mind." 
mity that scathe and scorch the soul, that penetrate the vital seat of happiness, and blast it, never again to put forth bud or blossom ;" and this we could perceive was his case. He was writhing under one of them, the madness of wounded affection, and though vanquished he would not yield. "I'll have my wife back again, by G-d," said he. "Look at thcse marks," pointing to a wound on each wrist, which it appeared he had purposely kept from healing; "they handcuffed me; * but, so help me G-d, I'll have her yet." Here a violent hysteric affection put an end to the scene; but it was evident that not only had the "iron entered into his soul," but that the foundation of his happiness was sapped, and that, in his then course of life, either his reason or his health must give way.

One week's experience of his proceedings-for he was never sober throughout the day-confirmed me in

* He alluded to a desperate attempt he had made to regain possession of his wife, after she had returned to her family at Chillington Hall; when it was found absolutely neccssary for the constables to handcutt him, before they could make themselves secure of his person. It has been stated that he knocked down eight persons in the rencontre. No doube he went "big with daring determinations," but he was foiled by a good louk-out. 
the above view of his case, and I thought it my duty to take some precautions. The first step was to interrogate his valet as to what instrument he had in his possession by which he could put an end to what, it he ever suffered himself to take a clear and sober view of it, must have been a barren and cheerless existence; and the next to inform his friends of my fears. Barring his mother, his uncle, Mr. Owen of Woodhouse, near Shrewsubry (one of his guardians), was his nearest relation; to whom I stated my apprehensions that his nephew would either go mad, or die, and very shortly too, and wished for his advice as to how I should act in case my suspicions should prove well grounded. His answer, as regarded myself, was kind, and that of a gentleman; but as concerned his nephew it was conclusive. He had never, he said, taken his advice in any one instance, therefore he declined offering it on the occasion on which I sought it; and muchsoever as he lamented the ruin that had befallen him, it was a consolation to him to reflect that he had not in the smallest degree contributed to it. (This letter is dated November 25, I $\&_{3} \mathrm{r}$, just twenty days after his nephew's arrival at Calais.)

It may be easily imagined that the arrival of my old friend at Calais, in the state in which he then 
appeared, was anything but what I could have desired. My pen was at that time employed on a very interesting subject, and I knew, from past experience, how many times in the day I should be interrupted by him. But I had shared his prosperity, and I was not going to desert him in his adversity. He did not, however, want for society at Calais. He gave dinners at his hotel; and as Epicurus's wise man would cultivate friendship, as he would the earth, for what it produces, there were plenty such wise men to be found in Calais.* This, however, was not the worst of it. Still wiser men followed him from London, as I shall straightways take occasion to show, as also how fortunately their designs were frustrated.

Although my house, with its humble fare, was always open to Mr Mytton, I never made one of his dinner-parties; but one evening, about nine o'clock, he came into my dining-room, accompanied by a man in a rough great-coat, whom he introduced as a livery-

- Here the character of the man appears in its true colour. One gentleman, previously unknown to him, borrowed his coat, with the Anson hunt button on it,-rather unceremoniously, as he said,- to go to a ball. He ordered his valet to line the gentleman's own coat sleeves with fish-hooks against he called for it the next day. 
stable keeper in Edgware Road, but who, in my eye, had every appearance of a London thief. On hearing Mr. Mytton say something of a draft or bill, I asked this person what was the amount of his demand on Mr. Mytton, when he replied, "Under sool." To cut this story short, then, I shall only state, that I cautioned my friend against giving bills in a foreign country, and also requested his old acquaintance, Mr. Longden, then residing at Calais, to caution him - for our suspicions were equally aroused-but we were both equally repulsed with "NIind your own business," or words to that effect ; and the rascal succeeded that evening, after he left my house, in getting his signature to a bill for $200 l$. * And even this was nearly being not the worst of it. A gang of swindlers, of which this fellow was one, were in the town with stamps suitable to $5000 \%$, for which amount they intended to get him to sign bills, with the promise of remitting him the money for them.

But this was only the commencement of that memorable evening's work. After repairing to the hotel

* The payment of this bill was stopped by placards in the streets of London, in which the names of other gentlemen who had been swindied by the same party appeared. 



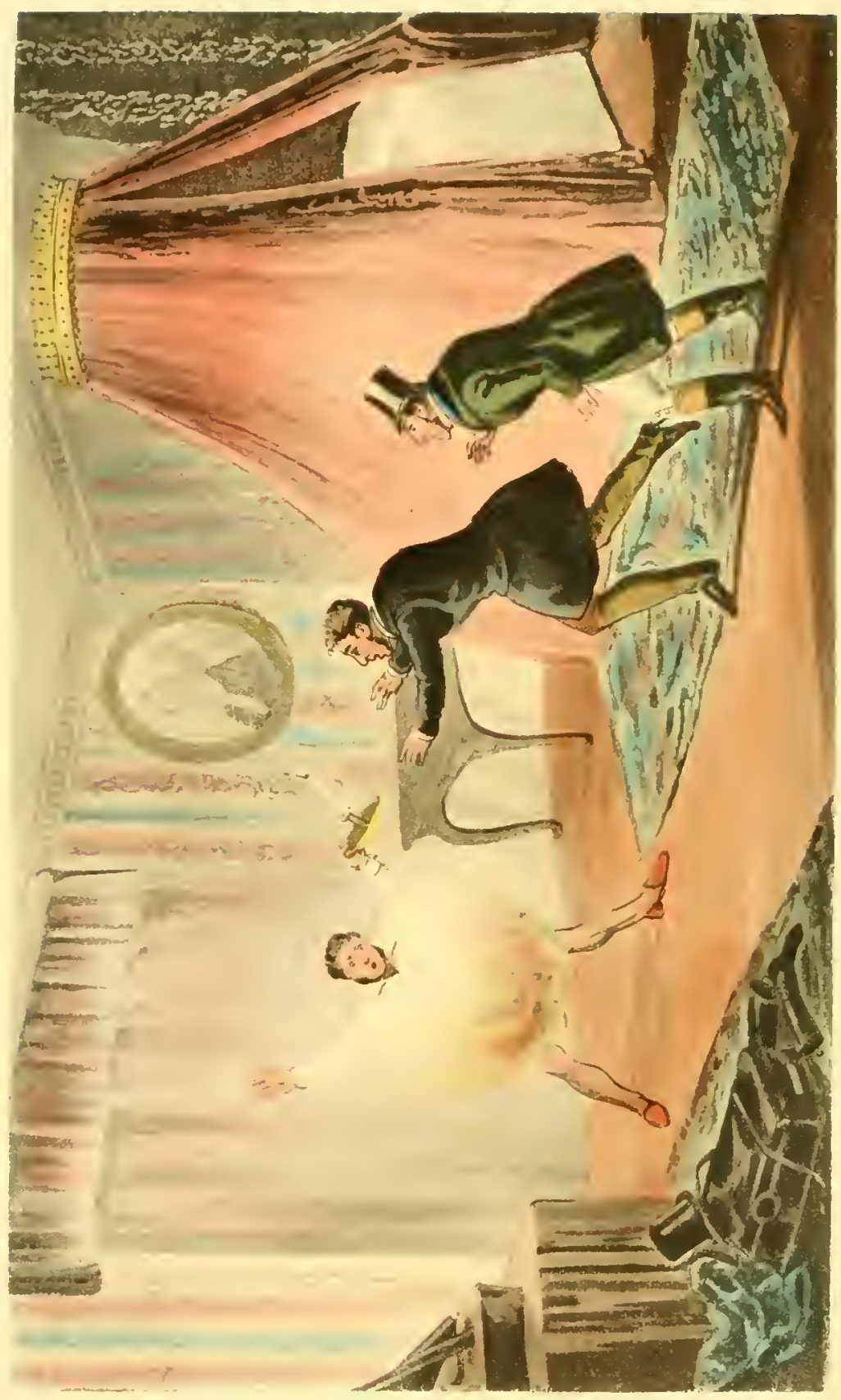




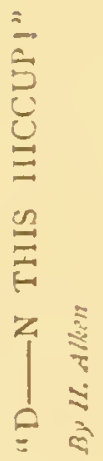



where the bill was signed, Mr. Mytton and his friend sallied forth to a "finish," and somewhere about midnight returned to the hotel; and now comes the climax.

But, reader, one word with you first. You have heard, no doubt, of many memorable deeds performed by fire. You have read that somebody set fire to Troy, Alexander to Persepolis, Nero to Rome, a baker to London, a rascally Caliph to the treasures of Alexandria, and the brave Mutius Scxvola to his own hand and arm, to frighten the proud Porsenna into a peace; but did you ever hear of a man setting fire to his own shirt, to frighten away the hiccup? Such, however, is the climax I have alluded to; and this was the manner in which it was performed. "D-n this hiccup," said Mytton, as he stood undressed on the floor, apparently in the act of getting into his bed; "but I'll frighten it away;" so, seizing a lighted candle, he applied it to the tail of his shirt, and, it being a cotton one, he was instantly enveloped in flames.

Now, how was his life saved? is the next question that might be asked. Why, by the active exertions of his London customer, and of another stout and intrepid young man that happened to be in the room, 
who jointly threw him down on the ground, and tore his shirt from his body piecemeal. Then here again comes John Mytton: "The hiccup is gone, by _—!" said he, and reeled naked into his bed.

It is easily to be supposed that the irregular life Mr. Mytton was at this time leading had its due weight with his valet, and, although he had been some four or five years in his service, he had left him that night to his fate, and was pursuing his own pleasures in Calais. The following morning, however, between the hours of seven and eight, he came to inform me of what his master had done, and wished me to come instantly to see him. "What doctor have you got?" said I. "None," replied the man. "Send for Dr. Souville immediately," added I, "and I will come to your master as soon as I am dressed."

Shall I ever forget the scene this morning presented? There lay Mr. Mytton, not only shirtless, but sheetless, with the skin of his breast, shoulders, and knees of the same colour with a newly-singed bacon hog. He saluted me, as usual, with a view-holloa, but I told him that was no time for joking, and asked him why he committed so silly an act, and one that might very probably be the cause of his death? In fact, had the flames caught his body one inch lower down, his 
intestines would have been burnt, and he must have perished. His answer was - the answer of a madman -that he wished to show me how he conld bear pain. The scene closed with the arrival of the doctor, who applied the usual palliatives, but whose opinion as to the result it was then almost useless to ask for.

Any man but John Mytton would have tried to have aided the exertions of his doctor to alleviate sufferings which very shortly became severe, but he absolutely added fuel to the fire. The more he smarted, the more he drank; but like the Spartan boy, he never squeaked. "Can't I bear pain well?" he would say to me six times in the day, and in truth he did bear it well. But although it sometimes happens that the spirit is willing whilst the flesh is weak, here the flesh was the stronger of the two; for the mind of the sufferer very soon became affected. I have, however, omitted to mention one act he committed the day after his accident which, if committed by any other man but himself, would have been evidence to have shown that he was already mad. "Is not - going to dine with you to-day?" said he to me. On iny answering in the affirmative, he observed that I might have asked himself to have met him. "It would cost you your life," 
resumed I; "you must be stark mad to think of going out in the state you are at present." He gave me one of those looks which generally implied mischief, and which were well understood by his friends; but said nothing more at the moment. Just after we were seated at our dinner, however, in walked John Mytton; but although he sat out the meal and half an hour besides, he fainted twice, and was glad to return to his bed. But even this is a trifle to what he afterwards did. He had been five weeks in his bed, when he declared he would dine with me on New Year's Day. Nothing but the strait waistcoat would have restrained him, and he came; and moreover, because there were not four horses to the carriage to take him back to his hotel-not three hundred yards-he would walk, without even a great-coat, but supported by two persons; and although the air was cold and damp, he was not a whit the worse for it. What would some people give for such a constitution as his! and how difficult was it even for him to destroy it!

Of all the uncertainties of our present state, said Dr. Johnson, the most dreadful and alarming is the uncertain continuance of reason; and although there may be "a pleasure in madness madmen only know," 
it is harrowing to the feelings of others to behold it. My prediction respecting Mr. Mytton was fulfilled; he became, to a certain extent, deranged in about a fortnight after the burning, and it was quite evident he would very shortly become a maniac. Symptoms at Jength gave apprehension of his becoming at times dangerous; the strait waistcoat was ordered, and the men were in readiness in the house to apply it. "Wait," said I, "and let me try, once more, if I can arouse him to a sense of his situation;" and, entering his chamber alone, the following conversation passed :-

"Mytton," said I, "I come to tell you that your doctors assure me you will be a corpse in three days, unless you give up drinking brandy." "So much the better," he replied; "I wish to die." "That is not the speech of a man of your good understanding," I observed; "you may yet see happy days, if you will give up drinking brandy. Will you promise me you will give it up?" He said he would not; but on my telling him there were men in the house ready to put his person under restraint, he said he would promise to drink only what his doctors might allow him; and this was all I wanted. The keepers and the waistcoat were dismissed. 
His mind soon experienced the benefit of this wholesome change; but the irritation from the burning brought his life into peril. In fact, Dr. Souville told me he did not expect him to live, apprehending typhus would ensue; and, as an old Warwickshire brother sportsman * who saw him, said of him, "No other man but Mytton would have survived." $\mathrm{He}$ would faint on being moved from his bed to his chair, and he had every symptom of sinking nature. Under these circumstances I had a duty to perform which I did not shrink from; but never should I have dreamt of making public the result, were it not that I consider it honourable to the man, and it cannot fail of being satisfactory to his friends. Sitting opposite to him, then, by the fireside, I thus, in pain, addressed him. "I think it right to tell you, your life is in danger; I know you too well not to be convinced that you will not scoff at what I am going to suggest. Would you like to see our clergyman, Mr. Liptrot? He is a liberal-minded, worthy man, without an atom of humbug about him." "Draw your chair by the side of me," said Mytton. On my placing it on his right, he requested me to place it on

- Mr. Henry Wyatt. 
his left, and to sit myself down upon it; when, putting his left hand into mine, he struck his breast violently with his right, and with as much vehemence as in his then weak state he could command, exclaimed, "I never intentionally injured any person in my life, and I hope God will forgive me." These words were followed by a flood of tears; yet how exactly do they resemble those of Manfred to the Abbot of St. Maurice :-

\footnotetext{
"I hear thee. This is my reply; whate'er

I may have been, or am, cloth rest between

Heaven and myself : I shall not choose a mortal

To be my mediator."
}

The offer of sending for the clergyman was declined, but without further remark.

Cicero says, No man in his sound mind is quite destitute of religion: and even unsound as poor Mytton's, to a certain extent, always was, I am quite sure he was not destitute of it, although his proud spirit was loth to own a dread of anything, either human or divine. But supposing he had never owned it to man, we are not to imply that he did not own it to his God; for although the fall of Solomon is told, we know nothing of his repentance. I shall have occasion, however, to show, that the subject of 
this memoir was a sincere, though perhaps a late penitent; and I rejoice at having it in my power to do so, as I should have been sorry to hear that he "died and made no sign."

There is a scrap of Latin which has often met my eye, and is as often applied to nations as to individuals, but I cannot say I know the author of it: "Quos Deus (or quem Fupiter) vult perdere, prizes dementat;" which is as much as to say, that those persons whom the Almighty wishes to destroy, He previously causes to grow mad (which is, I believe, the literal and only meaning of demento, a word not in use in elegant Latin). I know not on whose authority the conduct of man's Maker is thus, I think, impiously speculated upon; but should a fiat so dreadful have been really pronounced, let us hope it will plead in favour of some of the acts of poor John Mytton, for which, with a heart like his, nothing short of madness could possibly account or justify.*

- It never before fell to $m y$ lot to watch the motions and actions of persons labouring under a temporary aberration of the mind, much more to receive lelters from them. Amongst the numerous ones which my poor friend wrote to me in that melancholy situation, the following convince me that, however discordant may be the instrument of thought 
On the morrow of the day on which I had the conversation with Mr. Mytton on the serious condition in

(the brain) at the time, though some keys may jar, there are others which yield the usual tones to the same touch:-

“ Dfar Ramrod (for Nimrod),

"You shall not stay longer with old Jack Longden in my sittingroom, but come up stairs to see a Hero, late Chillington, die the death of a saint."

Here was the ruling passion, strong even in madness and in death, for he was very ill at the time. Hero was the horse he bought of me, which he afterwards called Chillington; and he married a daughter of the ancient house of Chillington. There were as many as. half-a-dozen dashes under some of these words. Again, there was the following, in whicls the fatal passion for the Circean cup-that cup which, like Nabal's, turned a heart of flesh to a he.ırt of stone-too plainly appears :-

\section{"DEAR RAM.,}

"Jam satis terris nivis atque diræ grandinis misit Pater, et rubente" porto. Here groes a bumper to old Ram.

$$
\text { (Signed), John MYTTON." }
$$

This extraordinary production is dated "The Gallies," and directed thus :- "Fall at a rasper! To Mytton's best friend." The quotation from Horace is worth notice, inasmuch as every word is rightly spelled, the punctuation correct, and the capital " $\mathrm{P}$ " in Pater as in the original. There were six dashes under the word "rubente," and four under "porto," but the inverted commas ceased at "rubente!" The following postscript was added to it:-

"Nummi si nolo custodi rendere vinctus

Fræmii num mi (eheus miseri !) restat ahenea turris?"

"Prison or not to prison-can it be a debt, as it's not self-contracted, 
which he then appeared placed, he asked me, as he lay in his bed, to get a sheet of paper and write what he dictated. I did so, and it consisted of the following lines :-

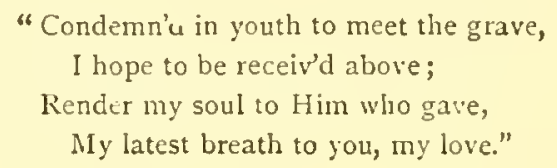

He then requested they might be placed in his view on the door of his chamber (where they remained for a considerable time). "And," said he, "when I die, I trust to your sending them to my wife." I told him I would do so; and had he died at that time, I should certainly have complied with the request.

non sponte suâ, nec voluntate meorum filiorum." Here it appears his Latin is not quite so correct, but he alludes to the impression, that he was not aware on what account his liberty was denied him. This last -epistle was succeeded by another the same day, which shows that the brain became more disturbed. "Dear Ram," H-l to pay; come here instantly, they are all found out-poison. Ever J. M." I have a hundred such notes, the dates of all which I marked, and I suppose Mr. Roberts, the proprietor of his hotel, had as many. On perusing several of them, I could have exclaimed with Shalispeare,-

"Oh, what a noble mind is here o'erthrown!" 
It would be both useless and tedious to describe the various scenes that passed in the chamber of my poor friend, who was guarded day and night by three persons at a time, after he recovered his strength; but some of these scenes would put the powers of description at defiance. His conversation, for example, with these persons, who were English smugglers, was, at times, ludicrous in the extreme, and highly characteristic of the man.* Previously to this precaution, however, rather an awful scene was witnessed by me. A servant from his hotel came to inform me that Mr. Mytton had got six carving-knives in his pos-

* There was nothing that medical skill or humanity could suggest left untried to relieve the sufferings of Mr. Mytton. Several of his friends sat up, or lay on a spare bed, the whole night in his room, and of course I took my turn. It happened one night that I was accompanied on my watch by a waiter from some hotel in London, who was sent over to Mr. Roberts' hotel for the purpose of learning the French language. "Nimrod!" exclaimed Mr. Mytton; bust I feigned sleep. "Nimrod!" he repeated, "I want to talk to you;" but I was still asleep. "Come, then," said he to the waiter, "sit by me, and talk to me. You have heard of ny hounds?" "Your hounds, sir?" said the man, a thoroughbred cockney; "I can't say as I ever did." "Why, you d-d fool, where have you lived all your life? Did jou never hear of Euphrates?" "I can't say as I did, sir," replied the man. "What!" said Mytton, " never heard of Euphrates the race-horse? I'll have you smothered to-morrow, by $\mathrm{G}-\mathrm{d}$ ! Get back to your great chair, and go to sleep !" 
session, and was by himself in his room. Mr. Vaughton and myself entered it, and such we found to be the case, with the trifling difference that only two of the six were carving-knives, the other four being dinner or case-knives. He was lying on his bed, with the six knives in his hands, when I placed myself at his side and Mr. Vaughton, a very powerful man, stood at the foot. "Heyday, Squire!" said I, "what are you going to do with all those knives?" "Come and lay down by my side," said he, "and I'll show you (of course, I begged to be excused). I have made your fortune, and old Vaughton's too-a hundred and fifty thousand pounds apiece for each of you; for I have found out that these knives will extract fire from flesh." "Ah!" said Mr. Vaughton; "but how much better would they do that, if they were warmed at the five!" "To be sure," replied our poor deluded friend; and, giving them into his hands, they were soon put outside the door. Now it will no doubt appear a mystery in what way these knives could have been procured; and well it may. But will it be credited, that they had been given to him by his own servant, of whom I had only a few weeks before required possession of everything, even to his 
nail knife, by which a wound to his person could be given? Such, however, was the case; and it is scarcely necessary to observe, that the man was from that hour forbidden to come near his person, and soon afterwards was discharged.

The effects of education on first-rate talent shine forth when little expected, as was the case with Mr. Mytton, even when his mental aberrations were nearly at their height.

In one of his paroxysms he talked eight-and-forty hours without ceasing, and, as it may be supposed under such violent excitement, a recollection of last year's clouds would not be more difficult than a record of the unconnected jargon which he at that time uttered. But in his calmer moments, when he saw me by his bed-side, he would quote Greek and Latin authors with surprising readiness, and when he found he was incorrect, would pause until he recovered the text. In several of these quotations it was beyond doubt apparent that the bereavement of his family and the desolation at Halston were present to his mind; for in some particular instances I could not be mistaken. In giving that beautiful passage from Sophocles, wherein CEdipus 
recommends his children to the care of Creon, I am quite certain he was applying it in his mind to the first-named calamity; and an epigram from the Greek Anthologia, on the fall of Troy and the death of Hector, which he would very often repeat, had a sympathetic allusion to the ruin at Halston and his own fall. But the following criticism could scarcely have been expected from a mind in ruins. In reply to the numerous messages he would send to the bar of his hotel, some answer was generally to be manufactured, and "master has not got such a thing in the house," was by no means an uncommon one. It happened one day, however, that the attendant in waiting brought him what he had sent him for, but, delivered it into his hands with the usual announcement--"Mr. Roberts hasn't got no such thing, sir," - he having procured it elsewhere.

"Why," said Mytton, looking the man in the face, in my presence, "you are a Greek."

“No, sir, I arn't," he replied.

"But I'll be — if you are not," continued Mytton, "for in Greek two negatives make the affirmative stronger ;" and roared into his ear, " $\chi \omega \rho \iota s$

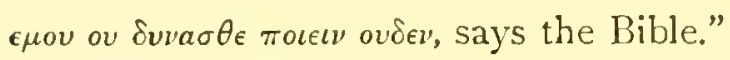

The fellow stared, and well indeed might Mr. 
Mytton's uncle say, as he did in his letter to me, when lamenting his nephew's situation, and contrasting it with what it might have been-" Heu, ubi lapsus!"

But we will bring this scene to a close. Having reason to believe that, either by his powers of eloquence or by the force of that sympathy in a British sailor for the absence of grog, which is inseparable from his character, and will be a formidable opponent to Temperance Societies on the coast, he had prevailed upon one or two of these otherwise honest guardians to procure him spirits by stealth, ${ }^{*}$ it was determined by Mrs. Mytton, his mother, who had for some time been in painful but unremitting attendance on her son, that I should proceed to London, and state his case to Dr. Sutherland, as, in fact, we were making no progress towards recovery. The result was two experienced attendants being sent to Calais, by whose skilful treatment an alteration. for the better was soon apparent, and their patient

- He would at this time frequently send for eau-de-Colozne, under the pretext of using it as perfume, or otherwise externally, on his person. We soon, however, by the quantity consumed, ascertained that he drank it! 
able to take his airings in a carriage. It is, however, singular, that the only time that it was found necessary to put my poor friend under absolute personal restraint, was during the time $I$ was absent from him in London, and on my return, John Mytton like, he spoke of it as a very good joke.

The scene now changes again, and somewhat of a brighter prospect appears. Although Mr. Mytton had every comfort, as well as every convenience, at the Royal Hotel at Calais,- the landlord of which, Mr. Roberts, is a person of superior education and conduct, and was much esteemed by his unfortunate guest,-yet when it was considered that he had been occupying the same apartments so long, in sickness and in sorrow, it was desirable, on the approach of spring, that he should breathe a purer air; and a chateau was looked for in the neighbouring country. But here arose a difficulty. The few persons who had such things to let were alarmed at the idea of a gentleman and his keepers, and fearing the occupation of them by such tenants might leave a stain on their premises, refused to let them on any terms. What, then, was to be done? His removal to England would have been his removal to a prison; so, at the request of Mrs. Mytton, I consented to hire a 
château, and to receive him as an inmate until his recovery was completed. But I went beyond this: I undertook to make a trial of managing him myself, without the aid of his keepers; and the first ten days bade fair for success. He conformed to regular hours; enjoyed his meals; did not exceed his bottle of light wine; was, I thought, never happier in his life, and the recruitment of his health was beyond all expectation. But, luckily for all parties, at the request of his mother, who was gone to England, his keepers still remained in Cala:s, to await the issue of the experiment; for at the end of a fortnight he stole away to Calais unobserved, got at the brandy bottle, and then it was all over with my "brief authority." It was with great difficulty that I could prevail on him to return to dinner for three successive evenings; and on the fourth he was outrageous, threatening to murder a gentleman at table who had been most kind to him in his illness. It then became necessary to send to Calais for his keepers; and by eight o'clock the next morning, with the advice of his doctors, he was under their care.

Provision was made for this somewhat anticipated change. The château afforded ample accommodation for the whole party; but as, in all such cases, it is 
necessary to separate the patient from persons and objects which are sources of mental excitement, Mr. Mytton and his attendants had apartments separate from mine, and which were arranged in the most convenient manner for all purposes of safety. The attendance of these young men acted like a charm upon their patient, who recovered his former serenity on being told that he was again placed under the surveillance of the police for striking a Frenchman in Calais. But let all those whose constitutions are the worse for wear, by indulging in midnight revels and strong drink, and who may take a glance at the Life of John Mytton, mark and digest what I am now about to state. When he left the town of Calais, he was gradually recovering his strength of body and mind, but was very feeble on his legs, and could scarcely enter a carriage without assistance. He had not been at this château a month before, by regular living and daily exercise in sea air, he was able to walk six or seven miles in the middle of the day without the slightest fatigue, and to take a walk in the evening besides. His meals were eaten with a relish, and without the aid of Cayenne pepper, to the use of which he before knew no bounds; and his sleep was tranquil and refreshing. Now methinks 
it will be asked, How did he employ his time? Why, painful but striking is the answer to this question. He to whom the whole world had appeared insufficient to afford pleasure, and who had spent hundreds of thousands of pounds in pursuit of it, was now completely happy in the occupation of picking up sea-shells in the morning, and washing them in vinegar in the evening! So eager was he in this his favourite pursuit, that he would scarcely finish his dinner before he would enter upon the lastmentioned office, and would absolutely stand for two or three hours at a time brushing shells with a nailbrush dipped in vinegar! They were then laid with great precision in drawers, which he would never suffer any one but himself to open. All this, with the perusal of the "Morning Herald," the "Age," and the Calais (French) Journals, formed the business of the day.

It is almost needless for me to state that at this period the intellect of my friend was in a state of great imbecility - the consequence of extreme exhaustion, produced by extreme excitement. Nevertheless, it was the opinion of his attendants, as well as of Drs. Souville and Winder, who saw him two or three times a-week, that, by pursuing the plan they were then 
acting upon, he would in time recover his strength of mind as well as that of his body; and there also was a chance-as his old friend and neighbour in his own county, Colonel Proctor, then at Boulogne, observedof his altering his former course of life, from the experience he might have of the benefits arising from temperance and exercise. But alas, poor man! this chance was denied him. At the end of the second month he was, by false representations made to his mother, once more let loose; and from that hour to the last of his life, his poor shattered bark was never out of a sea of troubles. He had nearly been suffocated with brandy on his voyage to London by the steamer, the day after he left the château; and, as was evident to all parties, so soon as he was caught in England he would be in a gaol! Why, then, was he taken to England? and why was his life thus suffered to be sacrificed? Why, merely to enable him to sign deeds conveying away the last remaining acre of his unentailed property, which he could not do when in the situation from which he was taken, and which, it appears, when done, did not secure his person from the griping fangs of the law. He did sign them, however, and his own death-warrant by the same act and deed. There might be other reasons for getting him to England. 
which it may perhaps be unsafe for me to commit to paper; to my mind they were conclusive.

I shall take but a bird's-eye view of his career in England; but, carrying on the allegory, we may compare his situation to that of small birds pursued by hawks. Every bailiff in London was on the lookout for him; and, above all places in the world, he went to Halston to avoid them! Oh! what must have been his feelings on the first view of his deserted hall-the scene of all his former splendour? They must have somewhat resembled those of "The Last Man," when viewing the capitals of the world, and himself alone left to mourn over them; but as they are incommunicable by words, I leave them to the imagination, and likewise to the sympathy of the reader.

"Such a house broke!

So soble a master fallen! All gone ! and not

One friend to take his fortune by the arm, And go along with him."

Let us hope, however, that he was neither sober nor in his senses-at all events, that some respite was in mercy granted to his intellectual faculties, as a guard to his heart, from the assaults of sufferings that might otherwise have been beyond man's nature to endure! But his stay here was short; he was hurried 
off to Shrewsbury gaol, whence, in the course of time, he was removed to the King's Bench Prison, in London.

Now here again comes "John Mytton!" During his sojourn in the first-named prison, he was visited by several of his old friends-influential gentlemen in the county-who offered their services in arranging his difficulties, provided he would put his affairs into their trust; but he rejected all their overtures. Either Caesar or nobody he was resolved to be so long as he was above ground; and how exactly did he come under that denomination of persons of whom Horace speaks, -

"Quem neque pauperies, neque mors, neque vincula terrent;"

and how plumply did he give the lie to the adage, that adversity is the school of reform! The toad was ugly and venomous; but he saw no "precious jewel in his head."

But there was something savouring of the serioromantic in Mr. Mytton's being placed in durance, for debt, in the prison of a town with which the deeds of his ancestors were so deeply and brilliantly associated -in a town in which his word would, but a short time before, have been good for ten thousand pounds, 
and in which he once sat high in the people's hearts: and also in relation to the altered situation in which he himself once stood towards the keeper of that prison. The governorship becoming vacant, the contest for it was a severe one, and it was solely by the influence and exertions of Mr. Mytton that the then gaoler, Mr. Griffiths, filled it. He, however, not only did credit, but honour, to his benefactor's choice, as no man in Shrewsbury was, I believe, more respected than he, neither could any man exceed him in the various and arduous duties he had to perform, tempering mercy with justice; and although Shakespeare says, "Seldom when the steeled gaoler is the friend of man," Mr. Griffiths was unceasing in his kind attention to his patron, now become his prisoner. Indeed Mr. Mytton not only acknowledged this to me, but told me he was very comfortable in Shrewsbury gaol!

On a writ of certiorari being executed, my poor degraded friend was conveyed to London, in the custody of MIr. Griffiths, and transferred to that of the Marshal of the King's Bench, where I saw him for the first time since he left the château in France. But what a change for the worse was here! He was the same bloated, unhealthy-looking son of Bacchus 
that he appeared on his arrival in Calais, and he had a leg in a state nearly approaching mortification. In fact, his surgeon told me he would owe his life-at all events, the preservation of his leg-solely to the kindness of a fellow-prisoner, who prevented his drinking spirits; and such, no doubt, was the case.

I am not able to say how long he remained in the Bench, but on his exit John Mytton-anus ex omnibus-appears again; but to what account shall we place the act I am about to mention; for it appears to me to want a name? It is not, however, without a plea. The heart of man has been elegantly compared to a creeping-plant, which withers unless it have something around which it can entwine; but towards what a frail trellage did that of this man yearn for its support! Walking one day over Westminster Bridge, the following dialogue occurred between himself and a female of a class which the reader will not be at a loss to name, but on whom he had never before set his eyes.

Mr. Mytton. "How do ye do?"

The Female. "Very well, I thank ye; how do you do?"

Mr. Mytton. "Where are you going?"

The Female. "I don't know." 
Mr. Mytton. "Then come and live with me; I'll settle 500 . a year upon you."

Here was no law's delay; no worm in the bud; no concealment feeding on the damask cheek; but love at first sight, if any love there was. The bargain being struck, the broomstick jumped over, the happy couple soon afterwards arrived at Calais, at the Crown Hotel; Mr. Roberts, under such circumstances, being compelled to decline the honour of their company. But the strangest part of the affair is to come. This young woman, then only in her twentieth year, whom no doubt some scoundrel had seduced and abandoned, was not only possessed of considerable personal charms, but proved to be very respectably connected,* and conducted herself towards her protector so much better than could be expected, considering whence she was imported, and that his lusty love had gone "in quest of beauty," and not "in search of virtue," that I saw a letter to her from his mother, acknowledging her kindness towards her son. But wife or mistress made no difference with

- The late Lord Arundel, who was at this time sojourning at the Royal Hotel, on his road to ltaly, confirmed to me the respectability of her connections on hearing their names mentioned. 
Mytton. If he were not, generally speaking, a madman to a certain extent, on the subject of a woman, and, above all, of a reoman he loved, he was a monomaniac; and some extraordinary scenes were the fruits of this extraordinary connection. The greeneyed monster played his part as usual, and at times a nod or a look was suspicion strong as holy writ.

I must hark back here for a moment. On the morrow after Mr. Mytton arrived from London, he was arrested for $25 \%$ at the suit of the holder of one bill out of four for $25 l$. each, which he had been most improperly induced to accept in favour of a person resident in Calais, who had not the slightest claim upon his liberality, and conveyed to the prison of the town. His solicitor being then with him, there was no difficulty in releasing him to the extent of that individual sum; but it was considered expedient to detain him in custody until it could be ascertained what was become of the three other bills; when it was at length agreed that two of them should be given up, and that his liability only extended to 50 l. Here, then, will appear the character of the kindhearted John Mytton in its true light. Almost any man but himself would have been outrageous at this breach of confidence and good feeling, but not so 
John My'ton. The first step he took after his release from the prison was, to call upon the person who had caused him to be thus disgraced, and to walk arm-in-arm with him on the market-place, lest, as he said, the affair might injure his character in the town, he being a professional man. Reader, I'll bar you from one book, and one book alone; you shall then search the pages of ancient and modern history, and I challenge you to produce me a nobler instance of a nobler heart than the one I have now given you. The power of bearing and forbearing, which constituted Epictetus's wise man, comes, perhaps, next to it in theory.

But the storm soon gathers again. After sojourning a certain time at the Crown Hotel, in Calais, with a score to his name of a thousand francs, he came to my house in the country, to inform me he should go to England on the morrow. It was in vain that I told him he could not do so without first paying his bill, which I knew he had not, at that time, the means of doing. He, however, put himself into the Boulogne coach the next afternoon, meaning to embark from that town, having, perhaps fortunately, informed the barber who shaved him of his intentions, which intentions the barber, of course, conveyed 
instanter to the landlord; and the following day found him in Boulogne gaol. Also luckily for him, his agent arrived the same day; but his creditor had previously agreed to release him, on an undertaking from Mr. Roberts, of the Royal Hotel, and myself, to bring him back to Calais. The distraining landlord has since paid the debt of nature; but he was quite free from blame with regard to the steps he pursued; and Mr. Mytton was kind as usual to him on his return.

Shortly after this, Mr. Mytton and his chère amie took their departure for Lisle; but what they did at Lisle I did not trouble myself to inquire. Their return to Calais, however, forms another interesting scene in this-I know not what to call it, but perhaps the ancient Greeks would have called it $\delta \rho \hat{a} \mu a$ rov Biov, or comcdy oj liff. Just as I was sitting down to dinner one evening of a very hot day in August, I espied a person at the bottom of my avenue, approaching my house on foot. "Is it possible," said 1, "that person can be Mytton?" Mytton, however, it was; and shall I ever forget the state he was in-shirtless, waistcoatless, neckclothless, with his trousers and coat stained with blood, as well as in a state of very great exhaustion from fatigue. Now 
then for his account of himself. He had set forward, it appeared, in a diligence from Lisle to Calais, but had quarrelled with Susan (his chire amie's name) at St. Omer, and refused to proceed in her company any farther. When she left him behind at St. Omer to proceed to Calais, he had nearly four napoleons in his pocket; but getting into a street-row in that town he had been well licked and robbed * of all save three Belgic sous. With this small sum he started to walk to Calais, twenty-seven long miles, and under a burning sun; but becoming dead beat before the sun set, he put up at a small public-house, or cabaret, by the road-side, and the account he gave of his proceedings in it was a most ludicrous one. He wheedled the old woman, he said, out of some supper; but then what was to be done for something to drink ? "Why," he continued, "I can leave part of my clothes in pawn in the morning, so got two glasses of gin and water, gin being cheaper than brandy." On refreshing himself at my house, and putting his person into something like a decent condition, he walked into Calais, and made it up with Susan.

The comedy is now at an end, at least for the

\footnotetext{
- I should rather say he had lost this money out of his pocket.
} 
present, and something very like a tragedy succeeds to it. Poor Mytton was, a few days after, again arrested for $200 /$, being the amount of the score he had run up at a certain French hotel in London, where himself and his partner had been sojourning after the bargain had been struck on the bridge, and from whence he had been obliged to bolt in a hurry, as the bailiffs were in the house in pursuit of him. But the landlord being a Frenchman, had recourse to the privileges of a Frenchman, and I was once more pained by seeing my friend looking through the bars of a French prison window. Here he was suffered to remain-the why and the wherefore can only be answered by his solicitors in London, as the sale of his estates had been completed-for fourtecn days; on the thirteenth day, I thought it my duty to inform his mother of his situation; and in four days from the date of my letter she was in Calais. It would be painful to me to relate, as well as to my readers to be made acquainted with, a detail of the acts and deeds of this unhappy man during the rest of the time he spent in Calais, where his mother remained to protect him as far as it was in her power to do so. But it was brandy, brandy, brandy, morning, noon, and night, which of course drove him to madness; and a 
disposition to insult the French people, made it necessary to remove him. England was again determined upon, where not only a prison, but the grave yawned to receive him, and in a prison he died. Thus fell John Mytton; by nature, what God must have intended every man should be; by education, or rather from the want of proper education, nearly at last what man should not be. The seed was good; but it fell among thorns and was choked.

So soon as I was informed that Mr. Mytton was. once more within the walls of the King's Bench Prison, I felt assured he would never quit them but on his bier,-neither did he. But as the poet says,

"Better to sink beneath the shock,

Than moulder piecemeal on the rock;"

and I was happy when I heard the fatal subpœna had arrived, for adversity had exhausted her vial, and it was evident that, with the exception of the unsubdued affection of his mother, there was, for him, no balm in Gilead. It appeared that in about three weeks after his incarceration, he was seized with paralysis of the extremities, which bade defiance to the treatment of Doctor Maton and Mr. Brodie, who indeed, from the first, considered it a case without hopes. It may be, however, a consolation to those who had a regard for 
him, to learn that his sufferings were not severe; that his mother was by his bed-side at the last, and that as he had been conversing rationally with his medical attendants within half an hour of his decease, his life must have departed like the flickering flame of a lamp which goes out by the last crackle. But it is astounding to think, from the rapidity with which his lamp of life must have burned, that he lived to complete his thirty-eighth year. As I said of him before, Nil violentum est perpetuam; Phaeton's car went but a day!

A brother sportsman and a brother prisoner (well known at Melton Mowbray) who, as I have before mentioned, had been extremely kind to my poor friend during his first and second incarceration, and who was a constant attendant on his sick-bed, wrote me, unsolicited, some interesting particulars relating to his illness and the last scenes of his eventful life, which it gives me pleasure to make known. The "virtue of suffering well," which Johnson allowed to Savage, could by no one be denied to Mytton, whose bearing and forbearing; as I have before shown, are perhaps not exceeded by any man's; but in the opinion of his friend he took much to heart this second confinement in the King's Bench, although his proud 
spirit would not suffer him to acknowledge it; and he thought it hastened his end. As to his dying in peace with all mankind, how could he die otherwise who never attempted to revenge himself on any human being, but who, though his communication was not "Yea, yea, or nay, nay," so far from demanding the eye for the eye, and the tooth for the tooth, would have actually given his cloak to him who stole his coat; whose heart was as warm as those of half the world are cold; and whose warmth of heart had brought him into the prison in which he died! And how did he die? As he appeared to live-in dread of nothing, human or divine? Certainly not; although it may tauntingly be said, he trusted to the delusive support of a death-bed repentance. Let no man, however, venture to pronounce sentence here, but leave it to that bar at which justice will be tempered with mercy; where, unless I formed a very erroneous opinion of the late Mr. Mytton-and who had a much more intimate knowledge of him than myself?-and a still more mistaken one of the attributes of Him by whom he will be judged, he will find acceptance before many who have carried a much fairer face to the world. Few receive the white garment and carry it without a stain before 
the judgment-seat. John Mytton certainly did not: it was soiled and stained with the impurities of our nature, with even more than can be placed to that account; and the world has no proof that they were attempted to be washed out by his tears; but I appeal to my own experience of him, to that of his brother prisoner and friend who attended him in his last days, in the hour indeed when the heart knows no guile, and in which the tongue seldom hazards an untruth, whether he did not then own to man what he had previously only owned to his God. Although it appears he did not consider his life in imminent danger, he had the church service read to him nearly every day, and more particularly on Good Friday, when he held a long conversation with his brother prisoner on the sacrament, but which, although he expressed himself very properly in his allusions to it, it does not appear he partook of. Of both his wives he spoke in the tenderest terms of affection, as also of his children by each, and expressed a strong desire to see his present wife and all his children together; but, alas! that wish was a vain one. Immediately after his decease, a cast was taken of his features by the celebrated phrenologist, Mr. Deville, in the Strand, at the express request of his mother, in which it is 
said the character of the man is very clearly developed.

The first public notice of his decease that reached this country was contained in a very neatly written paragraph in the "Globe," in which the following short but just character was given him:- " His princely magnificence and eccentric gaieties obtained him great notoriety in the sporting and gay circles, both in England and on the Continent. His failings, which leaned to virtue's side, greatly reduced him, and he has left numerous friends to lament the melancholy fact of his dying in a prison, which, contrasted with his former splendour, furnishes a striking illustration of the mutability of mundane affairs." This account went the round of the papers, with the exception of "Bell's Life in London," which inadvertently stated that he had spent the fortunes of two wives, but which the Editor immediately contradicted on my authority. That of his first, which was ten thousand pounds, was settled on his only daughter by her; what his second wife's fortune was, I never heard, but whatever it might have been, I have reason to believe it remained for the benefit of his younger children.

It is too much the practice of the world, at least so says the satire, to adore the rising sun, and to con- 
demn him when going down; but neither errors nor crimes (if such, reader, you will have them), nor adversity, could chill the grateful recollection of the splendour that had once illumined Haiston, and of the many, otherwise, perhaps sad hearts which had been warmed by its genial rays. But even independent of this, there was a tenderness and compassion of nature in both the sayings and doings of poor John Mytton, which had fixed him firmly in the hearts and affections of the people within many miles of his house, and there he remained fixed to the last. In proof of this, his funeral excited very general, indeed, I might say almost unequalled sympathy. The amazing number of three thousand persons were present at it, several appearing unable to stifle their feelings, and only obtaining relief by their tears. And what brought together this assemblage of persons of all conditions, even to the poorest? Not, as Shakespeare says, to

\footnotetext{
Their services to Lord Timon; his large fortune,

Upon his good and gracious nature hanging."
}

No; but to shed a tear on the bier of a man whose "large fortune" and whose "gracious nature" were no more; of a man who had died in a gaol; of one 
who, with "all his imperfections on his head," would never die in their hearts or memory! But no more of this. The subject is too painful to dwell on; and I should be untrue to myself if I did not admit, that my own tears would have mingled with those shed over the grave of John Mytton, and that they have more than once mingled with the ink which has traced his devious course and marked his miser. able end.

The following account of the funeral appeared in the "Shrewsbury Chronicle :"-

\section{“FUNERAL OF}

\section{THE LATE JOHN MYTTON, EsQ.}

"We last week announced the death of this gentleman. His body was conveyed from London, where he expired, to this town, with all solemnity. On passing through the town, many of the shops were closed; and crowds assembled to take a last look on his bier, and pay the homage of a sigh to the memory of Jolnn Mytton. We rejoice to say, that before his death the consolations of religion had been eagerly resorted to, and afforded him both comfort under affiction, and hope in the prospect of eternity. 
"A hearse with four horses (driven by an attached servant of the deceased), a mourning coach and four, and another carriage, formed the melancholy cavalcade through Shrewsbury. On the road to Oswestry, every mark of respect was paid; and at the Queen's Head, the corpse was met by a detachment of the North Shropshire Cavalry (of which regiment the deceased was Major), who escorted them to the vault in the chapel of Halston, where the remains were deposited at three o'clock on Wednesday afternoon. The procession was exceedingly well arranged under the direction of Mr. Dunn, of L.ondon, assisted by Messrs. Hanmer and Gittins, of this town, and entered the domain of Halston in the following order :

Four Trumpeters of the North Shropshire Cavalry. Capt. Croxon and Capt. Jones.

Thirty-two Members of the Cavalry.

A Standard of the Regiment covered with Crape. Forty-two Members of the Cavaly:

Adjutant Shirley and Cornet Nicolls.

Mr. Dunn (undertalier) and Mr. Gittins.

Two Mutes.

Carriage of the Revds. W. Jones and J. D. Pigott.

Two Mourning Conches and four, with the

\section{Pall-Bearers,}

Hon. T. Kenyon.

R. A. Slaney, Esq. M.P.

J. C. Peiham, Esq.
A. WV. Corbett, Esq. J. R. Kynaston, Esq. Rev. H. C. Cotton. 
The Hearse, drawn by Four Horses, with

\section{THE BODY,}

In a Coffin covered with Black Velvet, with massive Handles. richly ornamented, the Plate inscribed

' John Mytton, Esq. of Halston,

'Born 3oth of Sept. 1796,

'Died 29th of March i 834.'

(The Hearse was driven by Mr. Bowyer, the Deceased's

Coachman, who, with Mr. M'Dougal, another Servant, attended him in his last moments).

Mourning Coach with two Mourners, the Rev. E. H. Owen

(Decensed's Uncle), and the Hon. and Rev. R. Noel Hill.

Mrs. Mytton's Carriage.

Lady Kynaston's Carriage, with Mr. W. H. Griffiths and Mr. Cooper.

Carriage of A. W. Corbett, Esq.

Carriage of the Rev. Sir Edward K! naston, Bart.

Carriage of the Rev. E. H. Owen.

Carriage of R. A. Slaney, Esq. M.P.

Carriage and Four of the Hon. Thomas Kenyon.

J. Beck, Esq, in his Carriage.

Dr. Cockerill and Lieut. Tudor, in Carriage.

Carriage of T. N. Parler, Esq.

Carriage of W. Ormsby Gore, Esq., MI.P.

Carriage of Viscountess Avonmore.

Sereral Cars, \&c., with Friends.

Mr. Broughall, Agent.

About One Hundred of the Tenantry, Tradesmen, and Friends on Horseback, closed the procession. Among these were Messrs. Longueville, Cartwright, Bolas, Hughes, J. Howell, S. Windsor, J. Williams, Morris, Griffiths, Venables, D. Thomas, W. Francis, R. Edwards, Farr, Blandford, Rngers, Davies, \&ic. \&ic.

The Mutes were old men, brothers, John and Edward Nicholas, of Whittington; the latter was mute at the funeral of the decensed's grandfather: John was mute at the grandfather's funeral, the father's funeral, and that of Mr. Mytton. 
"A mourning peal was rung at Oswestry, and the bells of Shrewsbury, Ellesmere, Whittington, Halston, \&c., tolled during the day. The number of spectators was immense, and the road along which the procession slowly moved was bedewed with the tears of thousands who wished to have a last glance. Everything was conducted with the greatest order; but there was a great rush to enter the chapel on the body being taken out of the hearse. The body was placed on a shelf in the family vault, under the communion table of Halston Chapel, surrounded by the coffins of twelve of his relatives."

The family of Mytton, as has already been shown, is an ancient one; and the inhabitants of Shropshire and Wales are attached to it from many old historical, personal, and feudal recollections. Halston is called in ancient deeds Haly stone or Holy stone. Near it stood the abbey, taken down above a century ago. Meyric Lloyd, lord of some part of Uch Ales, in the reign of Richard I., would not yield subjection to the English Government, under which the hundred of Dyffryn $\mathrm{Clwyd}$, and several others, were then; and having taken some English officers that came there to execute the law, killed several of them. For this fact he forfeited his lands to the king; fled, and took 
sanctuary at Halston, where he was taken to the protection of its possessor, John Fitzallen, Earl of Arundel. In the Saxon era the lordship of Halston belonged to Edrio; at which time there were on it two Welshmen and one Frenchman. After the Norman conquest, Halston became the property of an Earl of Arundel, and was given by that family to the Knights of St. John of Jerusalem. In the 26th of Henry VIII. the commandry was valued at I6ol. I 4 s. Iod. a year. Upon the abolition of many of the military religious orders, Henry VIII. empowered John Sewster, Esq., to dispose of this manor to Alan Horde, who made an exchange with Edward Mytton, Esq., of Habberley; which alienation was afterwards confirmed by Queen Elizabeth. The church or chapel of Halston is a donative, without any other revenue than what the chaplain is allowed by the owner, and is of exempt jurisdiction. Halston was the birth-place of the famous General Mytton.

Immediately after the funeral his last will was read, in which he had bequeathed all that he had to leave equally amongst all his children, and to which the Hon. Thomas Kenyon, of Pradoe, near Oswestry, and R. A. Slaney, Esq., M.P. for Shrewsbury, were appointed executors. He had previously, at Calais, 
made a will to which Sir Edward Smythe, Mr. Owen of Woodhouse, Shropshire (his uncle), and myself, were appointed executors, in which his all was left to his only child by his first wife. The alteration, however, was immaterial, his "all," poor fellow! that is to say, his disposable personal property, being nothing; but it is consoling to think that estates amounting to 4500 l. per annum were out of his reach, by entail, and still remain to his family. Thus is it possible, that by the aid of a ten years' minority, and baring another "Gohn My'tton," Halston and its oaks " may yet flourish. $\dagger$

One question may very naturally be asked, Why was not that substitute for the law of Corinth, the

- It has been stated to me, that the amount of limber sold by Mr. Mytton at various times was 80,000 ., but 1 will not pledge myself to the fact.

+ But there was another John Mytton, and Halston has passed into other hands. Seges ubi Troja fuit, and prize Herefords have had the place of horses and hounds. "The W'orcester Journal" of January, 1838 , is answerable for the following :-

"John Myton Redivivus!-One day last week, young Mytton, a youth about twelve years of agre, the eldest son of the late lamented Squire of Halston, was out in a very hard day with the fox-hounds, and at the dusk of evening found himself in a turnip field, a considerable clistance from home, with his pony so dead beat that he could proceed no tarther. The youth had too much of the inherent spirit of his father 
High Court of Chancery, appealed to, to endeavour to stop the final dissipation of the unentailed portion of this fine property, since it is quite evident that for the last several years the unfortunate proprietor was not equal to the management of it; no, not more so than a child of six years old? This question is answered in many ways. Mr. Mytton's nearest connections were compelled, early in life, to leave him to his fate, their endeavours to save him from ruin having been always rejected by himself. He would not, like Savage, spurn the friend who presumed to dictate to him, but he heeded him not. That lie was half mad without drink, and rendered quite mad with it, no man who knew him latterly can for a

to leave his favourite, and therefore took out his handkerchief, tied if to the bridle of his pony and then to his wrist, laid down by the side of his wearied hunter, and went to sleep for the greater part of the night. On the first blush of morning he got up, and finding his pony refreshed, proceeded home, when his appearance dissipated the alarm which had been created by his unaccountable absence. He went to bed for a short period, and in two hours from his arrival at the hall of his ancestors was out ferreting rabbits, quite hearty and well. On being asked if he had not heard any one during the night, he said he had, and within a short distance too; and on being further asked why he did not call out and make his situation known, he replied he was afraid to do that, as he thought he should be well thrashed for being in the turnip field at that time of night." 
moment doubt; and a waggon-load of evidence could be produced to prove that fact. But let us suppose a commission of inquiry, a writ De Lanatico inquirondo to have been issued! Why, the result would have been this; he would have kept himself sober for two days, and, like Sophocles before the Areopagus, would have dumfounded his opponents. I am, however, quite certain, that from the time he arrived first at Calais to the day of his death, bordering on three years, he had not the slightest insight into his own pecuniary affairs, nor did he know, to thousands, how he stood in the world; and moreover, if he had had ten thousand pounds put into his hands any one day, he would not have had a shilling of it left by that day week! I can bring a host of evidence to back me in this assertion; and it was in vain that his friends asked him to call for something like a statement of his cash account from those who received his purchase-money for estates sold for upwards of fifty thousand pounds, subsequently to his arrival in Calais.

Having now traced this extraordinary character, this anomaly in human nature, this mixture of very right and very w:ong, this strange compound of contradictory qualittes, through the various stages of his 
eventful life, over which he may be said to have posted with the rapidity with which he travelled on the road, or rather with which he crossed a country after his hounds, knocking down everything before him, I shall bring his memoir to an end; and if I have followed him through a long train of errors or follies which mark his eventful course, it has not been for the purpose of exposing, but of accounting for them. If I have bared the sore with one hand, I have endeavoured to find a balm for it with the other, and it would be needless to demand of me, "Who hath required this at your hands?" I had the concurrence of those most nearly and dearly connected with him, one of whom observed, with no less feeling than truth, that the task I have undertaken would "do the living service and rescue the character of the dead." The man himself has passed away, yet his good deeds remain; as to his follies, we will cast them to the winds, but unfortunately for his character when alive, as well as for his memory now he is no more,

\footnotetext{
"There is a lust in man no charm can tame, Of loudly publishing his neighbour's shame : On eagles' wings immortal scandals fly, While virtuous actions are but born and die.'
}

He has been represented as a monster for acts he has 
nover committed, and why should the sun be thus permitted, and "falsely thus," to go down upon his shame? It is true there is one mournful blemish on his character, which, as has already been said, I wish could be washed in Lethe and forgotten, as I offer no extenuation for it but insanity. But if I can have given the lie to one single calumny which an ill-natured world has cast upon John Mytton unjustly, I shall be satisfied. He is the best man, says one of the best judges of mankind, that has the fewest faults; but he that has none is not to be found on this earth.* Poor Mytton's faults were the faults of the head, not of the heart, than which no man had a sounder or a kinder. They were numerous, I admit; but let not their number be augmented, neither let his many virtues be forgotten; and above all, remember the years in which he suffered adversity! This part of his history, however, cannot be without a useful moral. The contemplation of distress, no matter how created, corrects the pride of prosperity, softens the mind of man, and makes the heart better. Indeed, it was by such representations to the public

* Vitiis nemo sine nascitur; optimus ille Qui minimus urgetur.-HoR. 
eye that the nature of man was first polished and refined.*

The service done to the living only commences here. By pointing out the fatal rock on which $\mathrm{Mr}$. Mytton struck, a beacon is erected which might warn others, if they would see it, who are entering now on the vogage of life; and the vicissitudes of his latter days, and the melancholy circumstances of his death, are fearful lessons to the present possessors of what he once was master of, namely, all that might make life desirable and happy'. That memorable position then, that good is often the consequence of evil, is once more illustrated; and, as the poet says, it often happens, when they little dream of it, that

"The sons of men may owe The fruits of bliss to bursting clouds of woe."

Let me indulge in a lew more moral reflections, as such themes do not often present themselves to my pen. Man has been represented the miracle of nature,

- I one day told Mr. Mytton, in jest, I should write a history of his life, if I survived him. "I shall write it myself," he replied, "like Antoninus's кat ' eavroy!" In a frolic, I did write his epitaph some years since at Halston, and it was, I am sorry to say, prophetic. It ran thus :- 
and truly John Mytton does not give the lie to this. Perhaps no character in modern times can be found as a parallel to his, which is on one side dark and desolate, yet, if we turn the reverse, it is not difficult to determine to which side the balance inclines. But in human nature beauty and deformity are so closely linked, that, in my opinion, the character of no man can be very nicely weighed. Not only are there vices and virtues which bear so strong a resemblance to each other that it is not easy to determine where the former end and where the latter begin, but the virtues of some men are so obscured by their vices, and the vices of others so softened down by their virtues (as in both respects was the case here), that it is next to impossible to separate the chaff and cockle from the good grain. As for reconciling the contradictions and inconsistencies we have now been recounting, it

\footnotetext{
"Here lies John Mytton ; his short career is past, The pace was quick, and therefore could not last; From end to end he went an arrant burst, Determined to be nowhere, or be first. No marble monument proclaims his fate, No pompous emblems of funereal state; But let this simple tablet say, That, upon a much-lamented day, There went to ground, beneath this mouldering sod, An honest man-the noblest work of God."
} 
would be vain to attempt it, unless, as Johnson with his usual force says, "by those inconsistencies which folly produces and infirmity suffers in the human mind." At all events, an analysis of such a character as that now in our view, can only be effected by a sort of debtor and creditor account of good and evil, holding the balance with a charitable hand. But it must be said of Mytton, what Clarendon said of Cromwell, and what had been said of another more than a thousand years back, that his enemies (if he had any) could not condemn him without commending him at the same time. His cardinal virtue was benevolence of heart; his besetting sin a destroying spirit, not amenable to any counsel, and an apparent contempt for all moral restraint. In fact, like Charles the Fifth, who impiously asserted "there was but one Charles and one God," Mytton appeared to aim at similar notoriety; and every man pays a dear price for that. To a prodigality of heart he added a prodigality of hand, which no such fortune as his could suffice, and I am very much of Tom Penn's opinion, "that if he had had two hundred thousand a year he would have been in debt in five years." But although his extravagance might have reduced Mr. Mytton to want, he would have remained a man of unblemished integrity 
in rags, and nothing would have engaged him in dishonest practices. Oh no! He had a spirit which, it is true, was " marred in its beauty," but, in this respect, never forgetful of its own nobleness. He was faithful to his friends, an indulgent landlord, and a most kind master; and, last but not least in the novelty, with all this consideration for the happiness of others, he appears to have possessed very little for himself.

But he is now, ill-fated mar. safe in his urn ; and let no one attempt to throw more stones at his monument. There are specks in the sun, straggling weeds amongst the choicest flowers; and until the sons of Adam cease to be the sons of Adam, perfection must not be expected from them. From a retrospect of his career let this moral be drawn :- Life has been compared to wine; it must not be drawn to the dregs: and all who may have it in their power, as he had, to drain nature to satiety, will find out at last-as I myself have at last found out-that tranquillity of mind and health of body, which form the happiness as well as the security of life, are not to be enjoyed under the tyrant rule of passion, and nowhere without something like discretion to gride and direct us in our ordinary concerns and pursuits. 
Printed by Ballantyne, Hanson \& Co. Edinburgh \& London 




